\title{
DINÂMICA ESPACIAL DA FEBRE AFTOSA EM BOVINOS: UM MODELO MATEMÁTICO
}

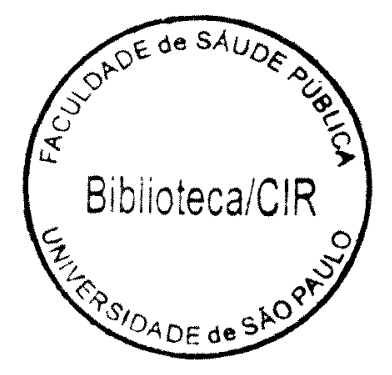

FERNANDO FERREIRA

Tese de Doutorado apresentada ao Departamento de Epidemiologia da Faculdade de Saúde Pública para obtenção do Grau de Doutor.

Área de Concentração:

Epidemiologia

ORIENTADOR:

PROF. DR. EDUARDO MASSAD

\section{SÃo PAULO}


Autorizo, exclusivamente para fins acadêmicos e científicos, a reprodução total ou parcial desta tese, por processos fotocopiadores.

Assinatura:

Data: 
À Adriana e Júlia 


\section{Agradecimentos}

Agradeço a todos que direta ou indiretamente colaboraram para a execução deste trabalho e a todos os docentes, pós-graduandos e funcionários do Departamento de Medicina Veterinária Preventiva e Saude Animal da Faculdade de Medicina V'eterinaria e Zootecnia da Universidade de São Paulo.

Agradeço especialmente ao Prof Dr. Eduardo Massad pela orientação e pelo exemplo de conduta cientifica, à Profa. Sônia Regina Pinheiro, ao Prof. Dr. Fumio Homna Ito e ao Prof. Dr. Silvio Arruda Vasconcellos pelo incentivo.

Ao Prof. Dr. José Soares Ferreira Neto sou grato pelo constante incentivo e pela iniciativa de implantar o Laboratório de Epidemiologia e Bioestatistica no qual foi desenvolvido este trabalho

Ao amigo e pós-graduando Sidnei Miyoshi Sakamoto sou grato pelo auxilio na organização dos dados da epidemia de Febre Aftosa de 1990.

Agradeço, finalmente, aos amigos e Médicos Veterinários do CIDASC (Companhia Integrada de Desenvolvimento Agricola de Santa Catarina) Clóvis Improta e Claudinei Martins bem como à própria CIDASC por ter cedido as informações referentes à epidemia de Febre Aftosa ocorrida no Estado de Santa Catarina no ano de 1990, registrando aqui o meu testemunho da rara qualidade dos dados produzidos por aquela instituição 


\section{Resumo}

Ferreira F. Dinâmica espacial da febre aftosa em bovinos:um modelo matemático. São Paulo; 2000. [Tese de Doutorado - Faculdade de Saúde Pública da Universidade de São Paulo].

Objetivo. Propôs-se um modelo matemático que simula a dinâmica espacial da Febre Aftosa em bovinos e que permite estimar a velocidade mínima de propagação da mesma, bem como a extensão de uma zona de bloqueio vacinal que impede a sua disseminação. Validou-se o modelo comparando-se os resultados das simulações com dados de uma epidemia real de Febre Aftosa ocorrida no ano de 1990 no Estado de Santa Catarina. Método. Utilizou-se um sistema de equações diferenciais que representa a história natural da doença em bovinos incorporando a dimensão espacial através da utilização da equação de difusão. As determinações dos valores das taxas de natalidade, de descarte, do coeficiente de difusão, do coeficiente de transmissibilidade e da capacidade suporte do meio foram realizadas com base nos dados populacionais do rebanho bovino do estado. Os valores das taxas de perda de imunidade, de mortalidade pela doença e de recuperação foram obtidos na literatura. Resultados. Obteve-se para o coeficiente de transmissão o valor de $\beta=6,62 \times 10^{-2}$ $\mathrm{km} \times \mathrm{dia}^{-1}$. O coeficiente de difusão foi estimado como sendo igual a $\mathrm{D}=3,19 \times 10^{-1}$ $\mathrm{km}^{2} \times$ dia $^{-1}$. Para as taxas de natalidade e descarte obteve-se os seguintes valores $\mathrm{a}=4,71 \times 10^{-5} \mathrm{dia}^{-1}$ e $\mathrm{b}=3,91 \times 10^{-5} \mathrm{dia}^{-1}$, respectivamente. A capacidade suporte do meio foi estimada como sendo igual a $\mathrm{K}=22,93$ animais $\times \mathrm{km}^{-2}$. O valor das constantes permitiu determinar o valor de $R_{0}$ para a Febre Aftosa como sendo igual a 15 . O 
tratamento matemático do modelo permitiu estimar que a velocidade mínima de propagação da epidemia era igual a $\mathrm{V}=490,74 \mathrm{~km} \times \mathrm{ano}^{-1}$ e que uma zona de bloqueio vacinal com extensão de $20 \mathrm{~km}$, na qual a proporção de animais protegidos é de $97,82 \%$, seria suficiente para impedir a propagação da epidemia considerando-se que a probabilidade de que um animal infectado encontre um suscetível nessa situação é de apenas 0,0001 . O modelo foi considerado válido através da comparação do resultado da simulação em duas dimensões com os dados reais de uma epidemia de febre Aftosa ocorrida no ano de 1990 no estado de Santa Catarina. Conclusões. A extensão da zona de bloqueio vacinal depende da densidade de suscetíveis presentes nessa área e pode ser determinada com base na probabilidade de que um animal infectado entre em contato com um animal suscetível, o que significa assumir risco conhecido de que isso aconteça. Considerando-se a presença de apenas 2,28\% de suscetíveis nessa zona, a probabilidade de contato entre animais suscetíveis e infectados, para um valor de $\mathrm{p}=0,60$ animal $/ \mathrm{km}$, varia de 0,025 a 0,0001 para uma extensão variando de 10 a $20 \mathrm{~km}$, respectivamente. O modelo foi capaz de simular adequadamente a difusão espacial da epidemia de Febre Aftosa ocorrida no Estado de Santa Catarina no ano de 1990.

Descritores: Modelo matemático. Febre Aftosa. Difusão. Epidemia. SIG. 


\section{SUMMARY}

\section{Ferreira F. Spatial dynamic on foot and mouth disease in bovines: a}

mathematical model. São Paulo; 2000. [Doctorate thesis - Faculdade de Saúde Publica da Universidade de São Paulo].

Objectives. It proposes mathematical model which simulate the spatial spread of the foot and mouth disease in bovines and allows to estimate the minimum velocity of its dissemination, as well as the extension of a barrier against the foot and mouth disease achieved by vaccination of susceptibles in areas ahead of the advancing wave. The model was validated by comparing the results of the simulation with the data of a real epidemy of foot and mouth disease which occurred in 1990 in the State of Santa Catarina. Methods. A system of differential equations which represent the natural history of the disease in bovines, incorporating the spatial dimension through the use of a diffusion equation, was used. The determination of the birth rate, the discard rate, the diffusion coefficient, the transmission coefficient and the environmental carrying capacity were made based on the populational data of the bovine herd of the State. The immunity loss rate, the mortality rate of foot and mouth disease and the recovery rate were obtained from literature. Results. For the transmission coefficient the value of $\beta=6,62 \times 10^{-2} \mathrm{~km} \times \mathrm{day}^{-1}$ was obtained. The diffusion coefficient was estimated as being equal to $\mathrm{D}=3,19 \times 10^{-1} \mathrm{~km}^{2} \times \mathrm{day}^{-1}$. For the birth rate and discard rate the following values were obtained $a=4,71 \times 10^{-5}$ day $^{-1}$ e $b=3,91 \times 10^{-5}$ day $^{-1}$, respectively. The environmental carrying capacity was estimated as being equal to $\mathrm{K}=22,93$ animals $\times \mathrm{km}^{-2}$. The value of the constants made it possible to determine the value of $R_{0}$ for the foot and mouth disease as being equal to 15 . The mathematical treatment of the model made it possible to estimate that the minimum velocity of 
propagation of the epidemy was equal to $\mathrm{V}=490,74 \mathrm{~km} \times \mathrm{year}^{-1}$ and that a barrier with $20 \mathrm{~km}$ of extension, in which the proportion of protected animals is $97,82 \%$, would be sufficient to hinder the propagation of the epidemy, taking into consideration that the probability of an infected animal meeting a susceptible, in this case, is only 0,0001 . The model was validated through comparing the results of the simulation in two dimensions with actual data of a foot and mouth epidemy that occurred in the State of Santa Catarina in 1990. Conclusions. The width of a foot and mouth disease barrier depends on the density of susceptibles present in this area and can be determined based on the probability that an infected animal comes into contact with a susceptible animal, which means assuming a known risk that this will occur. Considering that the presence of susceptibles in this area is only $2,28 \%$, the probability of contact between susceptible and infected animals, for a value of $p=$ 0,60 animals $/ \mathrm{km}$, varies from 0,025 to 0,0001 for an extension varying from 10 to 20 $\mathrm{km}$, respectively. The model was able to simulate adequately the spatial diffusion of the epidemy of foot and mouth disease that occurred in the State of Santa Catarina in 1990.

Key words. Mathematical model. Foot and mount disease. Epidemy. Diffusion. GIS 


\section{Índice}

pág.

INTRODUCÃO

OBJETIVOS

OBJeTIVO GERAL

OBIETIVOS ESPECIFICOS 15

MATERIAL E MÉTODO

Modelo Matemático e Estimativa dos Parámetros 16

Determinação da Velocidade de PropagaÇÃo da Epidemia

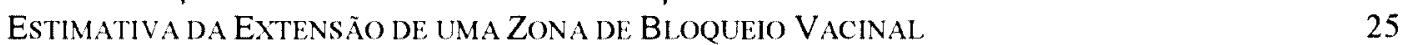

EPIDEMIA DE 1990 EM SANTA CataRINA

RESULTADOS

ESTIMATIYA DOS PARAMETROS AE B

ESTIMATINA DO PARAMETROK K 33

ESTIMATINA DO PARAMETRO $\beta$

Estimativa do Coeficiente de Difusão D 35

Estimativa da Velocidade de Propagação da Epidemia 36

Estimativa Da EXtensão da ZoNa de Bloquelo VaCinal. 39

VALIDAÇÃO DO MODELO

DISCUSSÃO

CONCLUSÕES

REFERÊNCIAS BIBLIOGRÁFICAS

$\begin{array}{lll}\text { ANEXO A } & \text { A I }\end{array}$

$\begin{array}{lll}\text { ANEXO B } & \text { B I }\end{array}$ 


\section{Introdução}

A Febre Aftosa (FA) é uma doença que acomete grande variedade de espécies animais domésticas e silvestres. Entre as domésticas são suscetíveis os bovinos, caprinos, suínos, ovinos, bubalinos e camelídeos. Sabe-se que mais de 70 espécies silvestres são suscetiveis à infecção natural ou experimental (HEDGER, 1981).

A enfermidade é causada por um RNA vírus da família Picornaviridae, gênero Aphtovirus que apresenta sete sorotipos (O, A, C, SAT 1, SAT 2, SAT 3 e Ásia 1) e 80 subtipos relacionados a diferenças antigênicas e identificados pela prova de fixação do complemento. A doença é caracterizada pela formação de vesículas ao redor dos cascos e da boca e pela morte súbita em bovinos jovens em decorrência de comprometimento cardíaco. A ocorrência da doença em uma propriedade, geralmente, ocasiona a disseminação por todas as espécies suscetíveis presentes. As principais características epidemiológicas do vírus responsáveis pelo padrão de ocorrência da doença em rebanhos animais são (PEREIRA, 1987):

- Grande quantidade de vírus presente nos exudatos das lesões, nas secreções naturais e nos tecidos animais;

- Elevada resistência do vírus no meio ambiente;

- Possibilidade do animal recuperado se tornar portador;

- Elevada transmissibilidade do agente;

- Período de incubação breve;

- Ausência de proteção cruzada entre os diferentes subtipos. 
Em bovinos, a via natural de infecção é através do trato respiratório, entretanto, o animal pode se infectar por meio da ingestão de alimentos contaminados, inoculação de vacinas contaminadas com vírus vivo, inseminação artificial ou fômites. A infecção através da ingestão de alimentos contaminados, embora seja possível, exige que grande quantidade de vírus esteja presente (WOODBURY, 1995).

O vírus se replica inicialmente na faringe (BURROWS e col., 1971), produzindo viremia e infectando diversos órgãos e tecidos. Grande quantidade de partículas virais está presente nas excreções e secreções cerca de 24 horas antes do aparecimento dos sintomas e sinais clínicos (BURROWS, 1968; BURROWS e col. 1981). Após a infecção, uma proporção significativa dos animais pode tornar-se portadora do vírus, principalmente os animais vacinados, sendo que, em alguns casos, pode-se isolar o vírus da faringe, por meio da prova de probang, 2,5 anos após a infecção (HEDGER, 1968). O estado de portador também pode ser observado em animais selvagens. Por exemplo, o búfalo africano (Syncerus caffer) normalmente está infectado por mais de um subtipo do vírus SAT (HEDGER e col., 1985; DAWE e col., 1994).

O papel epidemiológico dos portadores ainda não está definido, entretanto, acredita-se que animais portadores, pertencentes a espécies selvagens, possam ser importantes na manutenção do vírus nos rebanhos bovinos (HEDGER e col., 1985; DAWE. e col., 1994). No sul da África, o búfalo é considerado a principal fonte do vírus tipo SAT para os bovinos, o que é evidenciado pela presença de búfalos dentro ou ao redor de todos os focos de FA na região (HEDGER e col., 1985; DAWE e col., 1994). 
Em bovinos portadores, a quantidade de vírus recuperada na prova de probang é, normalmente, insuficiente para provocar a transmissão do vírus para um animal suscetível (WOODBURY, 1995), entretanto, alguns estudos baseados em evidências epidemiológicas têm sugerido a possibilidade de haver esse tipo de transmissão (OLITSKY, 1927; BURGI, 1928; RAMON, 1967). Portanto, a transmissão do vírus da FA de um bovino portador a um suscetível, se ocorre, é um fenômeno raro e mais importante em rebanhos com grande quantidade de animais suscetíveis (WOODBURY, 1995).

O período de incubação da doença é de dois a oito dias (FENNER e col., 1992; PEREIRA, 1987). O quadro clínico é caracterizado por febre, depressão, anorexia, queda na produção leiteira e aparecimento de vesículas ao redor da boca e nas extremidades dos membros dos animais. Vesículas preenchidas por um líquido amarelado podem ser observadas na língua, gengiva e lábios, lesões podem estar presentes também nas narinas e mufla. Nas patas as vesículas estão mais presentes no espaço interdigital; as lesões podem ainda aparecer nos tetos e tecido do úbere podendo produzir mastite grave em decorrência de infecção secundária (BROOKSBY, 1982).

A morbidade é bastante elevada, ao redor de $100 \%$, entretanto a mortalidade é de apenas $2 \%$ em bovinos adultos (THOMSON, 1994). Animais jovens, de até seis meses, podem apresentar mortalidade em torno de $20 \%$ em decorrência de miocardite que leva à morte súbita sem sinais aparentes da doença. O principal achado necroscópico consiste em lesões degenerativas do miocárdio e excesso de fluido pericárdico. O tecido lesado é substituído por tecido conjuntivo, de modo que, 
macroscopicamente o coração se apresenta com estrias caracterizando o chamado 'coração tigrado'.

As vesículas rompem-se em, aproximadamente, 24 horas provocando o aparecimento de úlceras que podem se estender por área bastante ampla da língua. A evolução das lesões apresenta etapas bastante características, apresentadas no Quadro 1, utilizadas em estudos epidemiológicos.

\section{Quadro 1 Evolução das lesões causadas pelo vírus da Febre Aftosa em bovinos a partir da infecção (MANN e SELLERS, 1990).}

\begin{tabular}{|ll|}
\hline Lesões & Período \\
\hline Vesículas íntegras na língua e/ou pata & $24-48 \mathrm{~h}$ \\
Vesículas rompidas parcialmente cobertas & $2-3$ dias \\
pelo epitélio; úlceras expostas & \\
$\begin{array}{l}\text { Epitélio necrótico e caseoso; tecido de } \\
\text { granulação evidente na língua ou partes da } \\
\text { boca }\end{array}$ & \\
$\begin{array}{l}\text { Perda do epitélio; processo de cicatrização } \\
\text { em evolução na língua; separação evidente } \\
\text { nas linhas de crescimento do casco }\end{array}$ & \\
\hline
\end{tabular}

Durante o período agudo da doença ocorre uma diminuição da produção que pode levar até seis meses para ser recuperada, além disso, o aborto e infertilidade subseqüente são seqüelas comuns.

Anticorpos do tipo IgM contra o vírus da FA podem ser detectados após quatro dias da infecção sendo que os títulos máximos ocorrem entre 7 e 14 dias, havendo então um declínio progressivo de modo que após 30 dias, anticorpos do tipo IgM já não podem ser detectados (BROWN e col. 1964). A produção de anticorpos do tipo IgG tem início após 10-14 dias e atinge o máximo ao redor do $28^{\circ}$ dia. Animais convalescentes de infecção natural apresentam imunidade a vírus homólogo por um período de aproximadamente um ano (FENNER e col., 1992). 
Animais jovens podem receber anticorpos contra vírus da FA de modo passivo através do colostro conferindo proteção por mais de seis semanas. A imunização ativa pode proteger o animal por períodos de 3 a 6 meses sendo que o período de imunidade está relacionado ao tipo de adjuvante utilizado. No Brasil utilizam-se vacinas inativadas e o adjuvante mais difundido é do tipo oleoso, conferindo imunidade por aproximadamente seis meses.

O diagnóstico laboratorial é realizado através da pesquisa do vírus no fluido vesicular ou epitélio. As técnicas utilizadas são fixação do complemento e/ou ELISA. Amostras negativas na fixação de complemento e ELISA devem ser passadas em cultivo celular observando-se a presença de efeito citopático. Evidenciando-se efeito citopático o cultivo é submetido à prova de fixação de complemento ou ELISA para confirmação. Não havendo a formação de efeito citopático deve-se proceder a segunda passagem procurando-se novamente evidenciar efeito citopático. Se não houver formação de efeito citopático o animal é considerado negativo.

A forma mais comum de contágio é através do contato direto entre um animal eliminando o vírus e um animal suscetível (WALKER, 1934) ou por meio de partículas de aerossol contendo o vírus. Este último mecanismo ocorre, principalmente, a pequenas distâncias. Em epidemias naturais, raramente o mecanismo principal de transmissão e manutenção da doença na população é a transmissão por objetos ou outros materiais contaminados com secreções, excreções ou tecidos animais, ou ainda por correntes de ar transportando, por longas distâncias, partículas de aerossol contendo o vírus. 
Nesse sentido, apesar de estudos realizados no norte da Europa (GLOSTER e col., 1982; FOGEDBY e col., 1960; HYSLOP, 1965) sugerirem, baseados em fortes evidências teóricas e circunstanciais, a possibilidade de transmissão do vírus à longa distância (além de $1 \mathrm{~km}$ ) por meio de aerossol contaminado com o agente e carreado por correntes de ar, esse mecanismo requer, para ser eficiente, uma grande quantidade de vírus sendo eliminada no ambiente por um período prolongado. A eliminação de grande quantidade de vírus seria mais provável se a fonte fosse constituída por rebanho suíno, uma vez que um suíno pode eliminar vírus em quantidade igual à eliminada por 2000 bovinos (GLOSTER e col., 1982).

Outro fator necessário seria uma baixa dispersão do vírus que naqueles estudos foi propiciada por ventos fracos sobre a superficie de oceanos, nos quais as correntes de ar quente ascendente são menores tendo menor efeito na dispersão das partículas. Além disso, haveria a necessidade da umidade relativa da atmosfera ser superior a $60 \%$, já que em valores inferiores o vírus é inativado em poucas horas. Finalmente, uma grande quantidade de suscetíveis deveria ser exposta por um período de várias horas.

Do exposto pode-se inferir que a transmissão por correntes de ar à longa distância pode ocorrer apenas em circunstâncias bastante específicas.

A distribuição geográfica dos sete tipos de vírus não é homogênea. Os tipos O, A e C são prevalentes na América do Sul, Europa, África, Oriente Médio e Extremo Oriente, já o tipo Ásia 1 está confinado às regiões do Oriente Médio, Extremo Oriente e Bálcãs. Os vírus tipo SAT 1, SAT 2 e SAT 3 estão restritos à África apesar de algumas ocorrências no Oriente Médio (THOMSON, 1994). 
As medidas de controle nos diversos países incluem o controle de movimento dos animais, vacinação dos suscetíveis, abate de infectados e contactantes e quarentena. Essas medidas foram suficientes para eliminar a doença em diversos países como, por exemplo, nos Estados Unidos da América (EUA), livre da FA desde 1929 (YU e col., 1997).

A OIE (Office International des Epizooties) é uma organização internacional que visa promover a saúde animal e que foi criada em 25 de janeiro de 1924 contando com 28 países membros. Hoje a OIE conta com 151 países afiliados e tem como objetivos informar os governos sobre a ocorrência de doenças nos países e suas formas de controle, coordenar ações internacionais que visem o levantamento e controle dessas doenças e regulamentar o comércio de animais e produtos de origem animal entre os países membros. Assim a OIE se encarregou de produzir o Código Internacional de Saúde Animal que trata de diversas enfermidades animais, inclusive a FA que está incluída em sua Lista $\mathrm{A}$, que contém doenças infecciosas que têm potencial de se espalhar rapidamente, que produzem conseqüências econômicas e de saúde pública graves e que produzem impacto no comércio internacional de animais e produtos de origem animal.

O Código Internacional de Saúde Animal (OIE, 1992) trata da FA em seu capítulo 2.1.1, no qual cria um critério de classificação dos países em relação à ocorrência da enfermidade. Assim, os países podem ser considerados livres de FA sem vacinação, livres de FA com vacinação, livres com zonas onde a vacinação é praticada e infectados. O código reconhece ainda a condição de zona infectada que é a ocorrência da enfermidade em determinada região de um país livre de FA com ou sem vacinação. 
Os artigos de $\mathrm{n}^{\circ} 2.1 .1 .3$ a 2.1.1.24 do código orientam os países sobre como proceder no comércio internacional de animais ou produtos de origem animal, de acordo com a classificação de cada uma das partes. A orientação se faz através de recomendações técnicas que visam minimizar o risco de introdução de um animal infectado nos países importadores. Assim, a presença da FA nos países que pretendam produzir animais ou produtos de origem animal para exportação representa grandes dificuldades no comércio exterior, principalmente com países que já a controlaram.

Cumpre destacar que grande parte dos mercados consumidores, constituídos principalmente pela Europa, EUA e Japão, são livres de FA. As dificuldades enfrentadas pelo Brasil no comércio internacional de animais e produtos de origem animal associadas aos prejuízos econômicos produzidos pela doença pressionaram autoridades e criadores para controlar a FA. Desse modo, em 12 de agosto de 1963 o então presidente do Brasil, João Goulart, publica no Diário Oficial da União, o Decreto de $n^{\circ} 52.344$ de 9 de agosto de 1963, no qual institui, no Ministério da Agricultura, a Campanha Contra a Febre Aftosa (CCFA) e dá outras providências.

A campanha se intensificou no início da década de $70 \mathrm{com}$ auxílio financeiro do Banco Interamericano de Desenvolvimento (BID) o que provocou redução significativa na ocorrência de FA no país. Entretanto, na década de 80 a FA era responsável, ainda, por prejuizos médios anuais na América do Sul da ordem de US\$210 milhões, não incluídos os gastos dos setores público e privado para manter a incidência da doença estável, da ordem de US\$70 milhões e US\$230 milhões anuais, respectivamente (OLASCOAGA, 1991). 
Os esforços no combate à FA continuaram no Brasil com intensidades diferentes nos diferentes estados, de modo que o Estado de Santa Catarina e Rio Grande do Sul foram declarados pela OIE, em sua resolução de $\mathrm{n}^{\circ} \mathrm{X}$, adotada pelo International Committee em 27 de maio de 1998, apresentada no Anexo A, zonas livres de FA onde se pratica a vacinação.

Em relação à América do Sul, os esforços para o controle da FA foram intensificados a partir da V Reunião Interamericana de Saúde Animal realizada no período de 27 a 30 de abril de 1987, em Washington DC. Nesta reunião estabeleceuse o Comitê Hemisférico de Erradicação da Febre Aftosa com objetivo de manter a determinação política dos países de eliminar a doença e buscar formas adequadas de financiamento (ASTUDILLO, 1992; OLASCOAGA, 1991).

Atualmente na América do Sul, são considerados livres da FA sem vacinação Chile e Uruguai. A Argentina e Paraguai são considerados países livres que praticam a vacinação e o Brasil é considerado país com zona livre onde se pratica vacinação.

Nos países que conseguiram controlar a FA, a principal preocupação passa a ser a vigilância epidemiológica com objetivo de evitar a reintrodução da doença. Isso pode ser demonstrado pela grande quantidade de estudos que têm procurado estimar o risco de reintrodução do vírus e o impacto econômico de uma possível epidemia (YU e col., 1997; NIELEN e col., 1996; GARNER e LACK, 1995; BERENTEN e col., 1992; BERENTEN e col., 1992a; SANSON e col., 1991; KRYSTYNAK e CHARLEBOIS, 1987).

Assim, os métodos de estimativa de risco têm sido utilizados pelos países que compõem o NAFTA (Nort American Free Trade Agreement) e a OMC ( Organização Mundial do Comércio) ao realizar comércio exterior, pois restrição 
arbitrária ao comércio de plantas e animais sem base científica pode resultar em sanções internacionais.

Em relação ao impacto econômico da FA, um estudo realizado no Canadá estimou a magnitude das perdas econômicas naquele país caso houvesse um surto desta doença (KRYSTYNAK e CHARLEBOIS, 1987). Os cálculos foram efetuados considerando-se as perdas ocasionadas por um surto ocorrido em 1952 que incluidos os gastos para eliminação da doença, somaram US\$ 1 milhão, sem contar os prejuízos decorrentes do embargo realizado pelos EUA por um período de um ano.

As simulações envolveram dois cenários possíveis. No primeiro haveria um surto pequeno com o envolvimento de 10 a 15 propriedades e a eliminação rápida do vírus com a destruição de 1500 a 2000 animais. No segundo, o surto ocorreria no leste do Canadá com dispersão rápida do vírus pelas províncias de Ontário e Quebec antes do controle efetivo da epidemia. Nesse cenário, o período para controle da doença foi estimado em seis meses, com a destruição de $1 \%$ do rebanho do leste do Canadá. O embargo aos produtos canadenses foi estimado como tendo a duração de um ano e meio.

Os resultados das simulações mostram que mesmo um pequeno surto, como o representado pelo primeiro cenário acarretaria perdas da ordem de US\$2 bilhões. Incluído os prejuízos resultantes do embargo econômico, esse prejuízo poderia atingir, no segundo cenário, US\$2,8 bilhões.

No Brasil também existe a preocupação com os potenciais prejuízos causados pela reintrodução de FA, principalmente nos estados que já controlaram a doença, como é o caso de Santa Catarina e Rio Grande do Sul, declarados livres de FA com prática de vacinação pela OIE, do Paraná e Goiás, há mais de dois anos sem foco, de 
Minas Gerais, sem registrar focos desde maio de 96, de Mato Grosso, sem foco desde janeiro de 96, e de São Paulo que não registra focos desde março de 96.

As ações a serem tomadas em caso de ocorrência de foco estão regulamentadas no 'Manual de Procedimentos em Focos de Febre Aftosa' (MA, 1973). Este manual preconiza a interdição e quarentena da propriedade onde esteja ocorrendo FA e das propriedades dentro de uma área perifocal, definida como sendo um círculo de raio variável de 5 a $10 \mathrm{~km}$ (na dependência da presença de barreiras naturais que dificultem a dispersão do vírus) com centro na propriedade positiva. A interdição deve se estender por, pelo menos, três semanas após o cura do último caso clínico de FA. Além disso, há a determinação de vacinação de suscetíveis na região de foco e perifocal bem como a restrição do trânsito desses animais pelo mesmo período.

As ações podem ser complementadas pelo abate dos animais infectados e contactantes se o foco se der em região na qual a prevalência de FA é baixa. O procedimento preconizado acarreta prejuízos às propriedades submetidas à interdição, que podem inclusive não apresentar casos de FA. Esse prejuízo pode ser maior ou menor, na dependência do comprimento do raio que irá delimitar a região perifocal. De fato, o que se observa é que a recomendação de que o tamanho do raio deva estar entre 5 e $10 \mathrm{~km}$ está baseada em experiência observacional, carecendo de determinação mais precisa.

A determinação da extensão da zona de bloqueio vacinal se reveste de maior importância quando se analisa um surto recente de FA ocorrido no Município de Porto Murtinho, Estado de Mato Grosso do Sul. Esse estado não apresentava focos de FA há 28 meses quando, no dia 27 de fevereiro de 1998, foi notificada a presença 
de FA (virus O1) em duas propriedades (OIE, 1998). Do total de 600 animais existentes nas propriedades 60 apresentaram sintomas. A origem do vírus não foi determinada.

Os procedimentos adotados para o controle do foco envolveram a interdição das propriedades afetadas e daquelas presentes na área perifocal, delimitada nesse caso por um círculo de raio igual a $25 \mathrm{~km}$. Nessa área impediu-se o trânsito de animais e produtos de origem animal, exceto para abate e consumo local. No dia 3 de março iniciou-se o abate sanitário de animais infectados e contactantes.

Ao final do surto pode-se contabilizar 119 casos de FA entre 2940 bovinos presentes na área. Desses, 1140 foram sacrificados e tiveram suas carcaças incineradas e 1800 foram abatidos para consumo. Entre ovinos, havia 64 animais presentes, os quais não apresentaram sintomas e foram sacrificados. Em relação aos suínos, havia 16 animais presentes, dos quais oito apresentaram sintomas, sendo que todos os animais foram sacrificados (OIE, 1998a).

O que chama a atenção nesse episódio é o tamanho do raio que delimita a região perifocal, ou seja, $25 \mathrm{~km}$. Esse raio é 2,5 vezes o maior raio preconizado pelo atual Ministério da Agricultura e Abastecimento (10 km). Isso evidencia o pavor, compreensível, das autoridades em relação à possibilidade de dispersão da doença nas regiões livres de FA ao mesmo tempo em que demonstra certa insegurança em relação à adoção de alguns parâmetros preconizados nas ações em emergências provocadas pelo surgimento de focos de FA, motivada justamente pela falta de fundamentação científica.

A conseqüência imediata desse tipo de ação é a imposição de um prejuízo maior que o necessário aos produtores agropecuários. Deve-se destacar que os 
produtores que tiveram que sacrificar os seus animais, o fizeram sem reclamar, dado a consciência dos mesmos em relação aos prejuízos maiores que poderiam advir da dispersão da doença pelo estado.

Há, atualmente, ferramentas que permitem a otimização dessas ações de controle em região de foco e uma delas é a utilização de modelos matemáticos que permitam simular a ocorrência da doença em populações, bem como o impacto de intervenções.

ANDERSON e col. (1981) estudaram a dinâmica da raiva em raposas na Europa com auxílio de modelos matemáticos, discutindo as possibilidades de controlar a doença através do sacrificio e vacinação dos animais. Posteriormente, MURRAY e col. (1986) modificaram o modelo de maneira que pudesse ser utilizado para avaliar a dispersão espacial da raiva na Inglaterra caso a doença fosse introduzida naquele país. Os autores determinaram a equação de onda que representa a frente epidêmica que se propaga com velocidade constante e estimaram a velocidade de propagação da eventual epidemia nas diferentes direções do território inglês. Além disso, o modelo permitiu estimar a extensão de uma faixa territorial adiante da frente de onda epidêmica, cuja população deveria ser imunizada para impedir a propagação da mesma.

Desse modo, propõe-se um modelo matemático baseado no descrito por ANDERSON e col. (1981) e modificado por MURRAY e col. (1986), que simule a ocorrência de uma epidemia de FA no Estado de Santa Catarina permitindo que se estime a velocidade de propagação da mesma, bem como a determinação da extensão de uma faixa territorial adiante da frente de onda epidêmica na qual a população deverá estar imunizada de modo a bloquear a sua disseminação. 
Os parâmetros utilizados no modelo foram obtidos de literatura e alguns foram estimados com base em epidemia de FA ocorrida no Estado de Santa Catarina no ano de 1990. Essa foi a última epidemia ocorrida naquele estado, sendo que a mesma será utilizada para validação do modelo. 


\section{Objetivos}

\section{Objetivo Geral}

Estudar a dinâmica da Febre Aftosa em populações animais incluindo-se os aspectos de dispersão espacial e suas implicações nas medidas de controle.

\section{Objetivos Especificos}

- Estimar o coeficiente de transmissão $(\beta)$ da Febre Aftosa no Estado de Santa Catarina.

- Estimar o coeficiente de difusão (D) da Febre Aftosa em Santa Catarina.

- Estimar a velocidade de propagação mínima da epidemia no Estado de Santa Catarina.

- Estimar a extensão de uma zona de bloqueio vacinal a ser interposta a uma frente de onda epidêmica de modo a impedir a sua propagação.

- Validar o modelo comparando os dados obtidos em simulação com os dados obtidos na epidemia de 1990 no Estado de Santa Catarina. 


\section{Material e Método}

\section{População Bovina do Estado de Santa Catarina}

Segundo OLIVEIRA e col. (1992) a população bovina do estado de Santa Catarina no ano de 1990 era constituída de 2.235.902 animais, distribuídos nas diversas propriedades rurais. Estas, por sua vez, são constituídas principalmente por minifúndios que praticam exploração mista, isto é, produzem carne e leite.

Dados gerados por MARTINS (1984) mostram que $81,85 \%$ dos estabelecimentos são mistos e que, considerando o tamanho, 35,13\% dos estabelecimentos têm área menor que $10 \mathrm{ha}, 60,38 \%$ dos estabelecimentos possuem de 10 a 99 ha e apenas $4,49 \%$ das propriedades apresentam tamanho igual ou superior a 100 ha.

A série histórica referente ao tamanho da população animal produzida por OLIVEIRA e col. (1992) e apresentada na Figura 1 demonstra a estabilidade do número de animais no período de 1972 a 1991. 


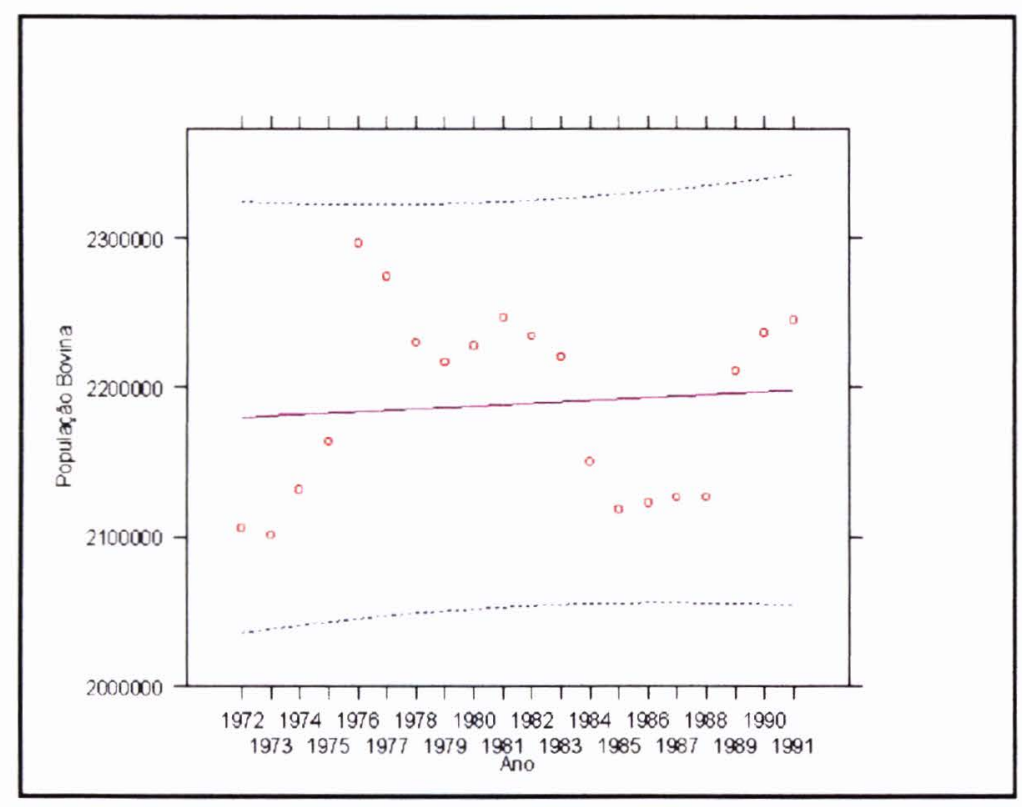

Figura 1 População bovina no Estado de Santa Catarina no período de 1972 a 1991.

\section{Modelo Matemático e Estimativa dos Parâmetros}

O modelo matemático utilizado para representar a dinâmica da doença tem como pressuposições as seguintes considerações:

- A população animal foi dividida em três compartimentos: um constituído pela densidade de animais suscetíveis (S), um pela densidade de animais infectados (I) e um pela densidade de animais recuperados $(\mathrm{R})$.

- Uma proporção $\beta$ dos contatos entre animais suscetíveis e animais infectados produzem indivíduos novos infectados. Assim $\beta S I$ indivíduos por $\mathrm{km}^{2}$ por unidade de tempo deixam o compartimento $\mathrm{S}$ em direção ao compartimento I, sendo que $\beta$ é chamado de coeficiente de transmissão. Os suscetíveis estão sujeitos ainda ao descarte a uma taxa $b$. 
- O individuo, uma vez infectado, pode morrer em decorrência da Febre Aftosa a uma taxa $\alpha$, pode recuperar-se da infecção a uma taxa $\delta$, tornando-se imune e saindo do compartimento I para o compartimento $R$, ou pode ser descartado a uma taxa $b$.

- O animal recuperado pode perder a imunidade a uma taxa y tornandose suscetivel e retornando ao compartimento $\mathrm{S}$ ou pode ser descartado a uma taxa $b$.

- A reposiçăo de animais é realizada a uma taxa a aplicada a todos os compartimentos considerando-se a possibilidade de que o proprietário realize a reposição independentemente da condição do animal. A taxa de mortalidade natural foi substituida pela taxa de descarte uma vez que normalmente o animal é descartado antes que ocorra a morte natural $\mathrm{Na}$ dinâmica da população considerou-se que a taxa de descarte apresenta caracteristica de densidade dependência, ou seja, o descarte da população é condicionado pela capacidade de suporte do meio $(\mathrm{K}$, determinada pela prática agropecuária da região) e pela densidade da população (N). A Figura 2 apresenta um diagrama de blocos representando a dinâmica da doença na população. 
- O modelo considera que a difusão da doença é realizada pelos animais infectados.

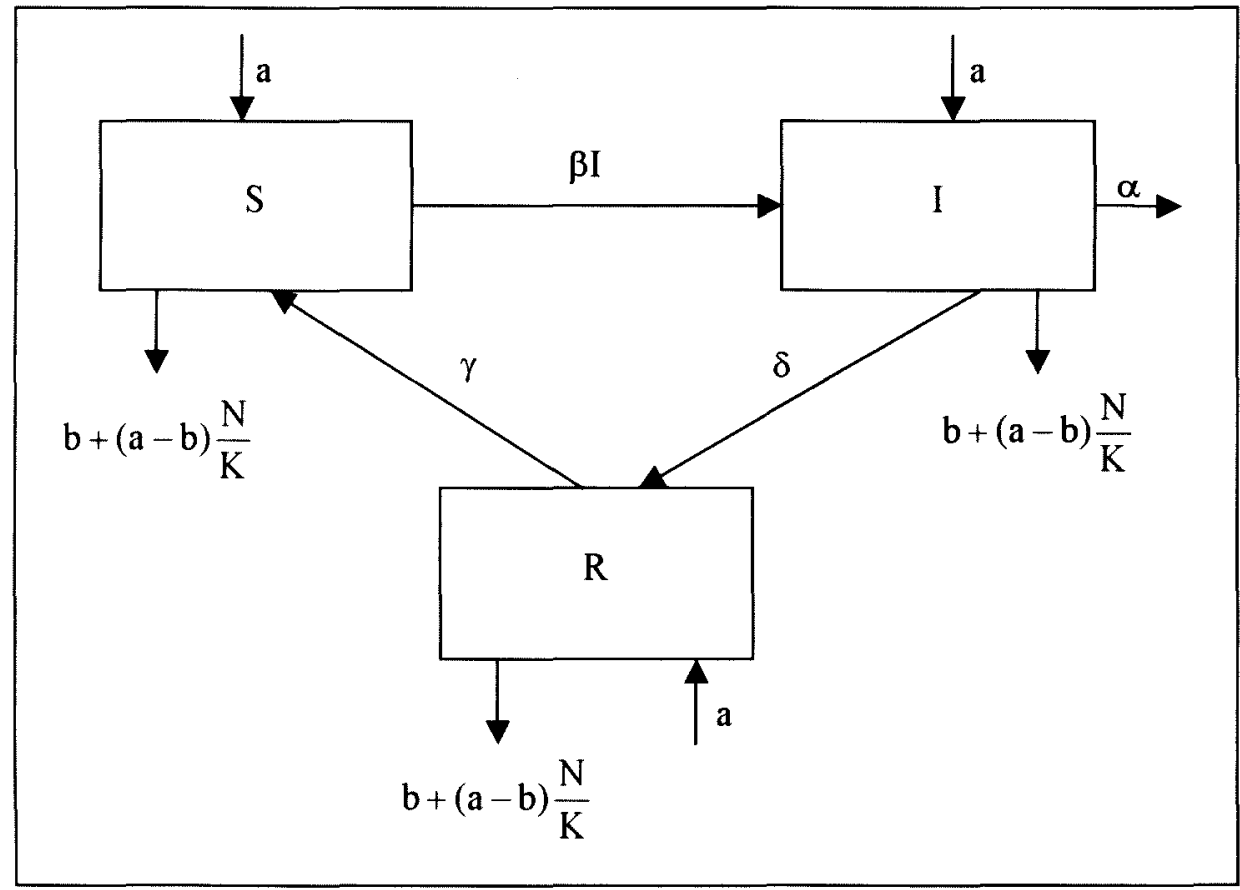

Figura 2 Diagrama de blocos mostrando a dinâmica da Febre Aftosa em populações animais

A determinação do valor médio de $\mathrm{K}$ foi realizada com base em série histórica de 20 anos, produzida por OLIVEIRA e col. (1992) e apresentada na Figura 1, que permite considerar a população bovina no período como sendo estável. A densidade média no período representa a capacidade de suporte média (K).

Para a simulação do modelo em duas dimensões considerou-se que a população bovina em cada município estava estável e que a densidade animal para cada município representaria a capacidade suporte para aquele município. Além disso, considerou-se que inicialmente toda a população seria suscetível a exceção de um único foco introduzido no município de Taió. A Figura 3 apresenta a imagem utilizada para realização das simulações em duas dimensões. 


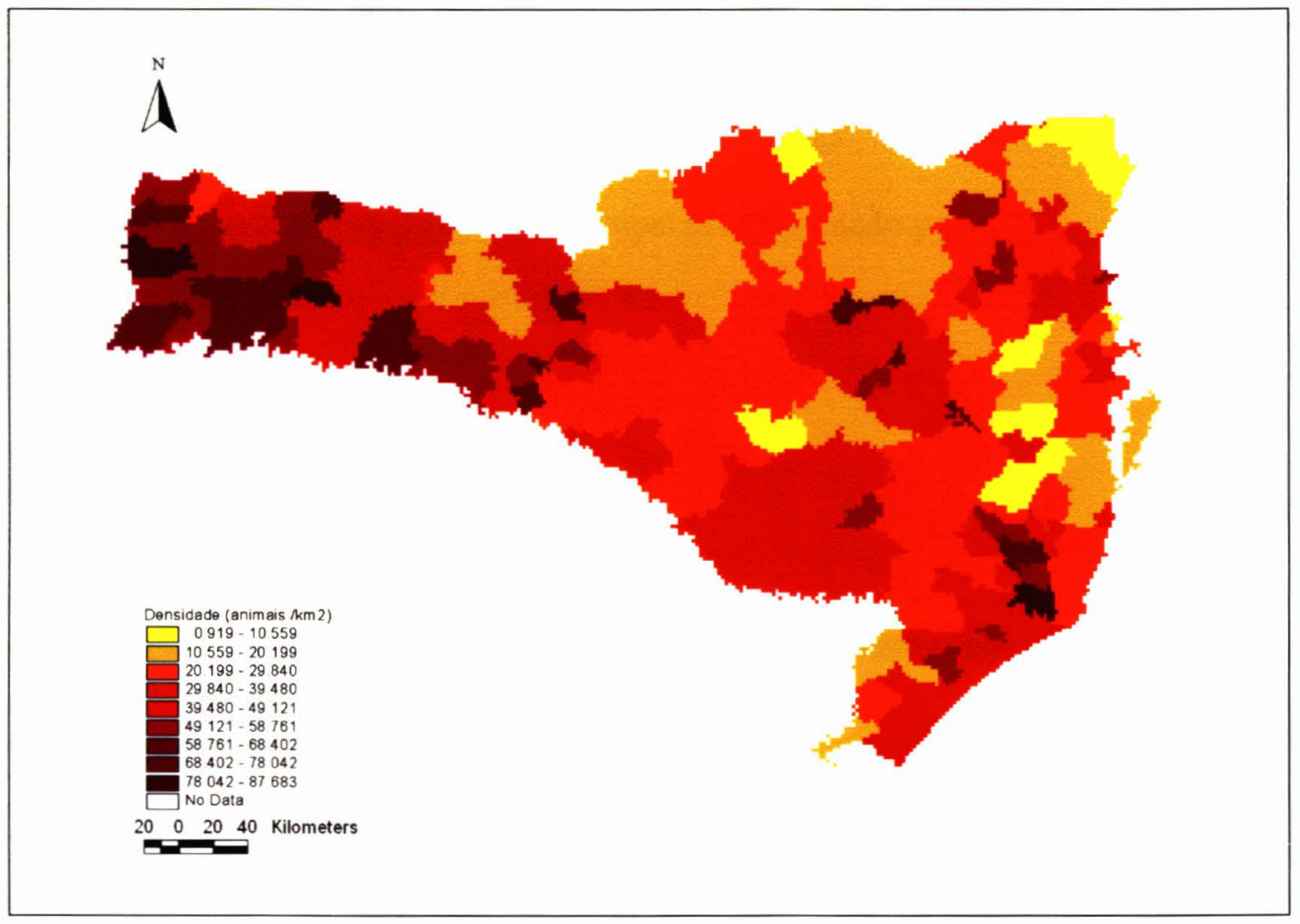

Figura 3 Densidade populacional por município para o Estado de Santa Catarina no ano de 1990. Essa imagem foi convertida em uma matriz na qual a posição dos elementos representa a posição no mapa e o valor armazenado representa a densidade populacional para o ponto. Essas densidades foram consideradas como sendo a capacidade suporte para cada um dos pontos. Sobre ela realizou-se a simulação em duas dimensões como será descrito posteriormente

Os valores das constantes $\alpha, \gamma$ e $\delta$ foram estimados a partir de dados obtidos em literatura, conforme apresentado na introdução, e estão representados na Quadro 2.

Quadro 2 Valores das constantes utilizadas no modelo estimadas com base em informações obtidas na literatura.

\begin{tabular}{|c|c|c|c|}
\hline Taxa & Constante & Valor $\left(\mathrm{dia}^{-1}\right)$ & Fonte \\
\hline $\begin{array}{l}\text { Mortalidade } \\
\text { pela FA }\end{array}$ & $\alpha$ & 0,0020 & THOMSON, 1994 \\
\hline $\begin{array}{l}\text { Perda de } \\
\text { Imunidade }\end{array}$ & $\gamma$ & 0,0027 & $\begin{array}{c}\text { FENER e col., } \\
1992\end{array}$ \\
\hline $\begin{array}{l}\text { Recuperação } \\
\text { da FA } \\
\text { (Cura) }\end{array}$ & $\delta$ & 0,1 & $\begin{array}{c}\text { MANN e } \\
\text { SELLERS, } 1990\end{array}$ \\
\hline
\end{tabular}

Para a taxa de mortalidade pela FA $(\alpha)$ considerou-se que $2 \%$ dos animais 
infectados morrem em até 10 dias (periodo que vai da infecção à cura). A taxa de perda de imunidade $(\gamma)$ foi calculada considerando que o tempo médio $(\tau)$ que um animal permanece no compartimento recuperado $(\mathrm{R})$ é dado por:

(1) $\quad \tau=\frac{0}{\int_{0}^{\infty} R(t) d t}$

Considerando a taxa de perda de imunidade constante temos que $\mathrm{R}(\mathrm{t})$ é dado por:

(2) $\quad R=R_{0} e^{-x}$

Aplicando-se ( 2) em ( 1 ) e resolvendo temos que:

(3) $\quad \tau=\frac{1}{\gamma}$

Sabendo que $\tau$ é aproximadamente 1 ano (FENNER e col., 1992) pode-se facilmente estimar $\gamma$. Promovendo-se as devidas alterações, a taxa de recuperação pode ser estimada como sendo $1 / \Omega$, onde $\Omega$ é o tempo médio que um animal leva para se recuperar da doença - estimado em aproximadamente 10 dias (FENNER e col., 1992; PEREIRA, 1987).

O valor de $a$ foi estimado considerando-se as informações de crescimento populacional fornecidas por OLIVEIRA e col. (1992). A estas informações ajustouse o modelo de crescimento populacional apresentado a seguir, o que permitiu estimar o valor de $a$ : 


$$
N=N_{0} e^{a t}
$$

Onde: $\mathrm{N}=$ População no tempo $\mathrm{t}$

$\mathrm{N}_{0}=$ População inicial $(\mathrm{t}=0)$

$a=$ Taxa de natalidade

Dados obtidos por MARTINS (1984) mostram que $81,85 \%$ dos estabelecimentos produtores de Santa Catarina são mistos, ou seja, destinam-se a produção de carne e leite. Além disso, 35,13\% dos estabelecimentos têm tamanho menor que 10 ha, $60,38 \%$ dos estabelecimentos possuem de 10 a 99 ha e apenas $4,49 \%$ das propriedades apresentam tamanho igual ou superior a 100 ha. Assim pode-se concluir que Santa Catarina é um estado formado principalmente por minifúndios com estrutura de exploração familiar na qual o número médio de animais por propriedade é pequeno como demonstrado pela Figura 4. Neste tipo de estrutura produtiva, um animal tem uma expectativa média de vida que pode ser estimada em 7 anos. Este dado foi utilizado para determinar o valor da constante $b$.

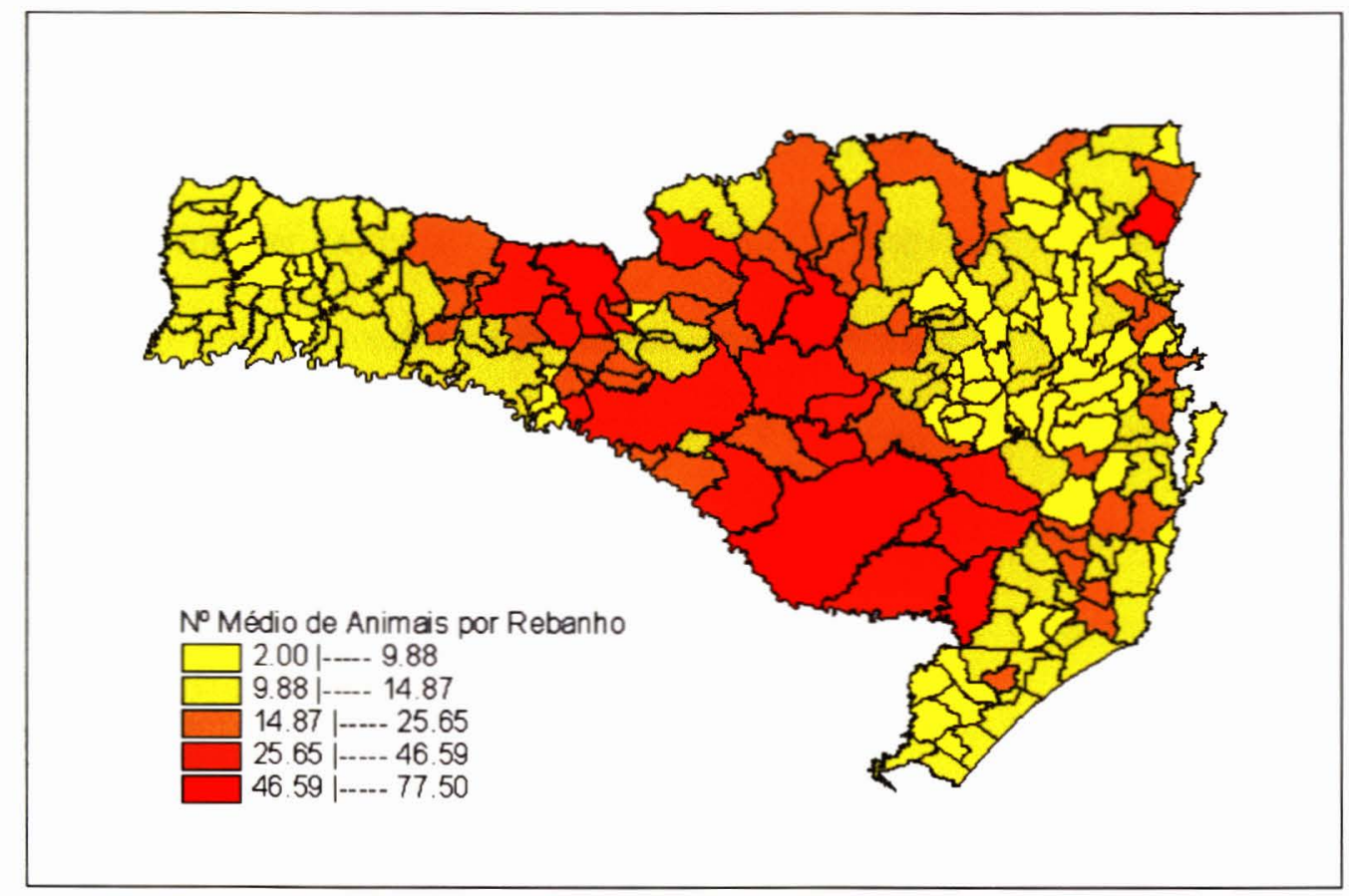

Figura 4 Número médio de animais por propriedade por município, Santa Catarina, 1991 
As equações abaixo representam a dinàmica da doença com a difusão ocorrendo em apenas uma dimensão posteriormente tratou-se do processo de difusão em duas dimensões

(4) $\quad \frac{\partial I}{\partial T}=(a-\delta-\alpha) I-\left[b+(a-b) \frac{N}{K}\right] I+\beta S I+D \frac{\hat{c}^{2} I}{\partial X^{2}}$

$$
\frac{\partial S}{\partial T}=a S-\left[b+(a-b) \frac{N}{K}\right] S-\beta S I+\not R
$$

$$
\frac{\partial R}{\partial T}=(a-\gamma) R-\left[b+(a-b) \frac{N}{K}\right] R+\delta I
$$

onde a população total é dada por:

$$
N=S+I+R
$$

Nas equações acima, D è o coeficiente de difusão estimado a partir de informações sobre o sistema de criação existente no Estado de Santa Catarina. Assim, sua estimativa foi realizada considerando-se a área média percorrida por um animal infectado durante um dia. Este modelo foi utilizado para obter a velocidade de propagação da epidemia bem como estimar a area em torno de um foco na qual os animais deverão ser vacinados de modo a bloquear a dispersão da doença

Para estimar o valor de $\beta$ utilizou-se o conceito de Reprodutibilidade Basal da doença descrito por ANDERSON (1982). Chama-se de Reprodutibilidade Basal de uma doença e representa-se por $R_{0}$, o número de casos novos produzidos por um único individuo infectado introduzido numa população inteiramente suscetivel durante o periodo em que este individuo é infeccioso. Uma vez introduzida na população a doença pode atingir o equilíbrio no qual um indivíduo infectado consegue transmitir, em média, o agente para um individuo suscetivel durante o 
periodo em que é infeccioso. Nessa situação a Reprodutibilidade Efetiva (R) é igual a um.

Considerando que a população seja, em média, intrinsecamente similar quanto às caracteristicas epidemiológicas (independentemente de idade, localização geográfica, carga genética, etc.) pode-se considerar que o número de infecções secundárias produzidas por um individuo infectado é linearmente proporcional à probabilidade de que um contato aleatório seja efetuado com um individuo suscetivel (ANDERSON e MAY, 1991). Assim, a relação entre a reprodutibilidade basal e a reprodutibilidade efetiva é dada por:

( 5 ) $\quad R=R_{0} S$

onde: $\quad \mathrm{R}=$ Reprodutibilidade efetiva

$\mathrm{R}_{0}=$ Reprodutibilidade basal da doença

$\mathrm{S}=$ Proporção de suscetíveis na população

Numa situação espacialmente homogênea $(D=0)$, a reprodutibilidade basal, como definida acima, é estimada com base no conjunto de equações apresentado em ( 4 ) e representada por:

(6) $\quad R_{0}=\frac{\beta K}{\alpha+a+\delta}$

Aplicando-se a equação ( 6 ) na equação ( 5 ), e considerando-se a população no equilibrio ( $R=1$ ), pode-se estimar $\beta$ como sendo:

( 7) $\quad \beta=\frac{\alpha+a+\delta}{K S^{*}}$

onde: $\quad \mathrm{K}=$ Capacidade suporte

$\mathrm{S}^{*}=$ Proporção de indivíduos suscetíveis no equilíbrio

$\alpha=$ Taxa de mortalidade por FA

$a=$ Taxa de natalidade 
$\delta=$ Taxa de recuperação

A equação ( 6 ) permite estabelecer uma densidade populacional crítica, abaixo da qual a doença não se propaga na população, pois, da definição de $R_{0}$, podese esperar que, para que a doença se dissemine na população, o valor da reprodutibilidade basal deve ser superior a 1 , ou seja, um individuo infectado deve ser capaz de infectar em média mais de 1 suscetivel durante o período em que é infeccioso. Assim tem-se:

$$
\frac{\beta K}{\alpha+a+\delta}=1
$$

$$
K_{c}=\frac{\alpha+a+\delta}{\beta}
$$

Logo, para que a doença se dissemine na população tem-se que a capacidade de suporte do meio deve exceder a uma capacidade de suporte crítica, $K>K_{c}$.

\section{Determinação da Velocidade de Propagação da Epidemia}

A determinação da velocidade mínima de propagação da epidemia foi realizada tratando-se o modelo apresentado em ( 4 ). Esse tratamento matemático utiliza valores apresentados em Resultados (como os valores de $a$ e $b$ ), desse modo, para tornar a leitura mais fácil, o mesmo foi incluido em Resultados.

\section{Estimativa da Extensão de uma Zona de Bloqueio Vacinal}

A estimativa da extensão de uma zona de bloqueio vacinal foi realizada simulando-se o modelo apresentado em ( 4 ). A simulação foi realizada considerando-se uma faixa de $300 \mathrm{~km}$ de extensão, na qual inicialmente do 
quilômetro zero ao quilômetro 98,32 a população animal era constituída apenas por animais suscetiveis presentes com densidade igual à capacidade suporte média de Santa Catarina.

Do quilômetro 98,32 ao 245,81 a população era constituída apenas por animais suscetíveis a uma densidade menor que a capacidade suporte crítica apresentada em ( 9 ). Essa redução na proporção de suscetíveis pode ser obtida através do sacrificio de animais ou através da imunização dos mesmos (neste último caso não estaria reduzida a capacidade suporte e, sim, a densidade de suscetíveis. Entretanto, manter uma fração da população imunizada tem o mesmo efeito que a redução da capacidade suporte, uma vez que a dinâmica da doença se dará na fração não imunizada). Finalmente, do quilômetro 245,81 ao 300 a população era constituida por animais suscetiveis a uma densidade igual à capacidade suporte média de Santa Catarina

Na simulação iniciou-se a epidemia no quilômetro zero introduzindo-se individuos infectados a uma densidade de dois animais por quilometro quadrado. A simulação permite verificar a propagação da frente de onda na população suscetivel e o seu decaimento quando encontra a zona na qual a capacidade suporte é menor que a capacidade suporte crítica conforme pode ser observado na Figura 5.

Como a primeira frente de onda tem amplitude maior que as frentes subseqüentes, ao determinar-se a extensão de uma zona de bloqueio que seja capaz de impedir a propagação da primeira frente, a mesma será capaz de impedir as subseqüentes.

Nesse processo de simulação numérica, a densidade de infectados não irá zerar em nenhum ponto havendo sempre a possibilidade de que, passado tempo 
suficiente, a epidemia ressurja na outra extremidade da zona de bloqueio. Isto ocorre como consequêencia do fato de que para o modelo a população como é contínua no tempo e espaço e por utilizar equações de difusão. Assim, a determinação da extensão da zona de bloqueio não deve ser feita verificando-se se a frente ressurge ou não na outra extremidade.

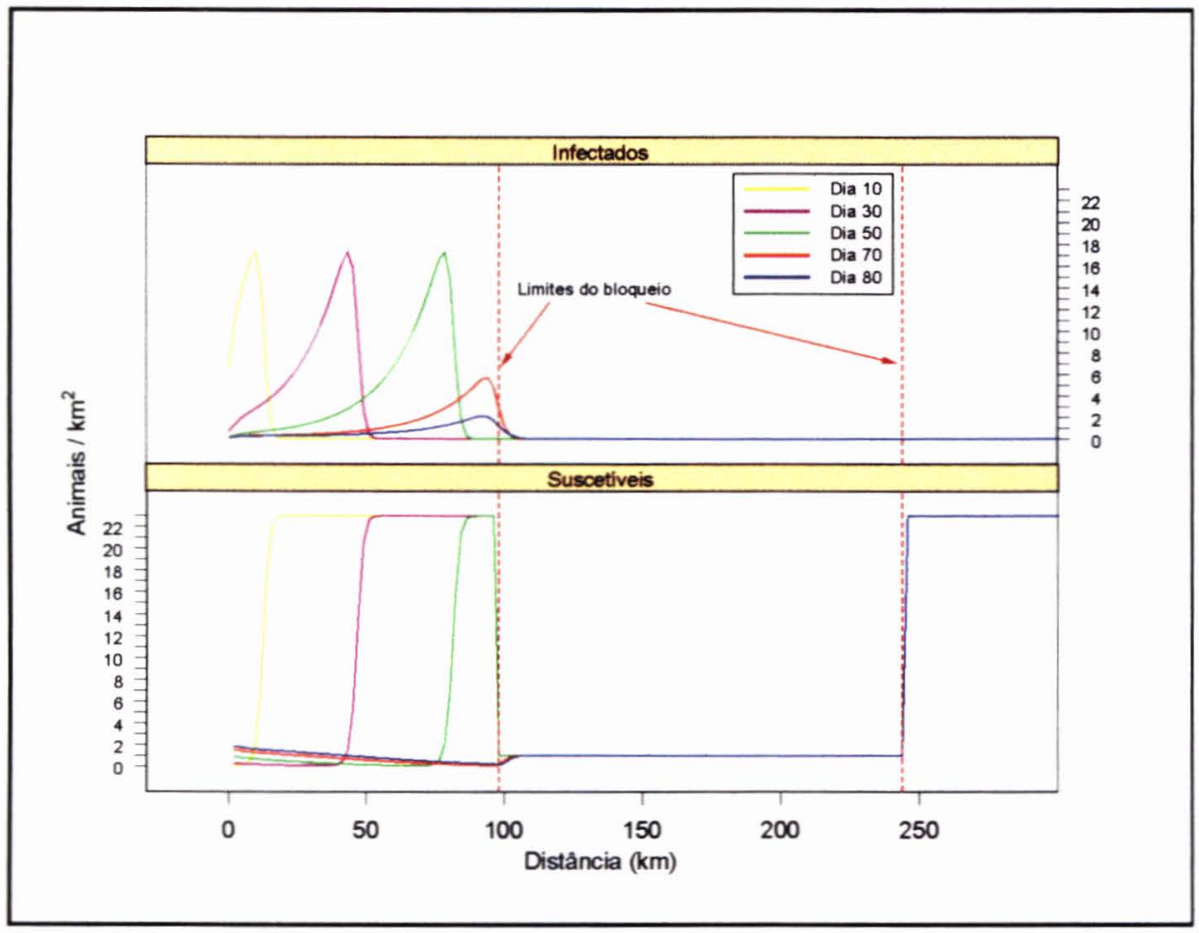

Figura 5 Diagrama representado o comportamento da frente de onda epidêmica ao encontrar zona cuja densidade de suscetíveis é menor que a capacidade de suporte crítica

MURRAY e col. (1986) sugerem que essa determinação deve se basear em dois parâmetros $p$ e $m$. O valor $p$ corresponde ao número total de infectados existentes na zona de bloqueio após um tempo $t$ crítico e $m$ corresponde à proporção de indivíduos infectados existentes após esse mesmo tempo crítico na extremidade distal da zona de bloqueio em relação ao número de infectados existentes nesse tempo na extremidade proximal da zona de bloqueio. Considera-se extremidade proximal da zona de bloqueio aquela em que a frente de onda penetra inicialmente. A 
Figura 6 exemplifica o comportamento do número total de infectados na zona de bloqueio em função do tempo, para capacidade suporte igual a 1 animal $/ \mathrm{km}^{2}$.

Os valores de $p$ e $m$ são escolhidos arbitrariamente com objetivo de que a probabilidade de um indivíduo infectado encontrar um suscetível após o tempo crítico seja suficientemente pequena. Assim, quanto menores forem os valores de $p$ e $m$, menor a probabilidade desse encontro e mais extensa será a zona de bloqueio.

Para o cálculo da extensão da zona de bloqueio para o Estado de Santa Catarina realizamos diversas simulações variando-se os valores de $p, m$ e da capacidade suporte no interior da zona de bloqueio.

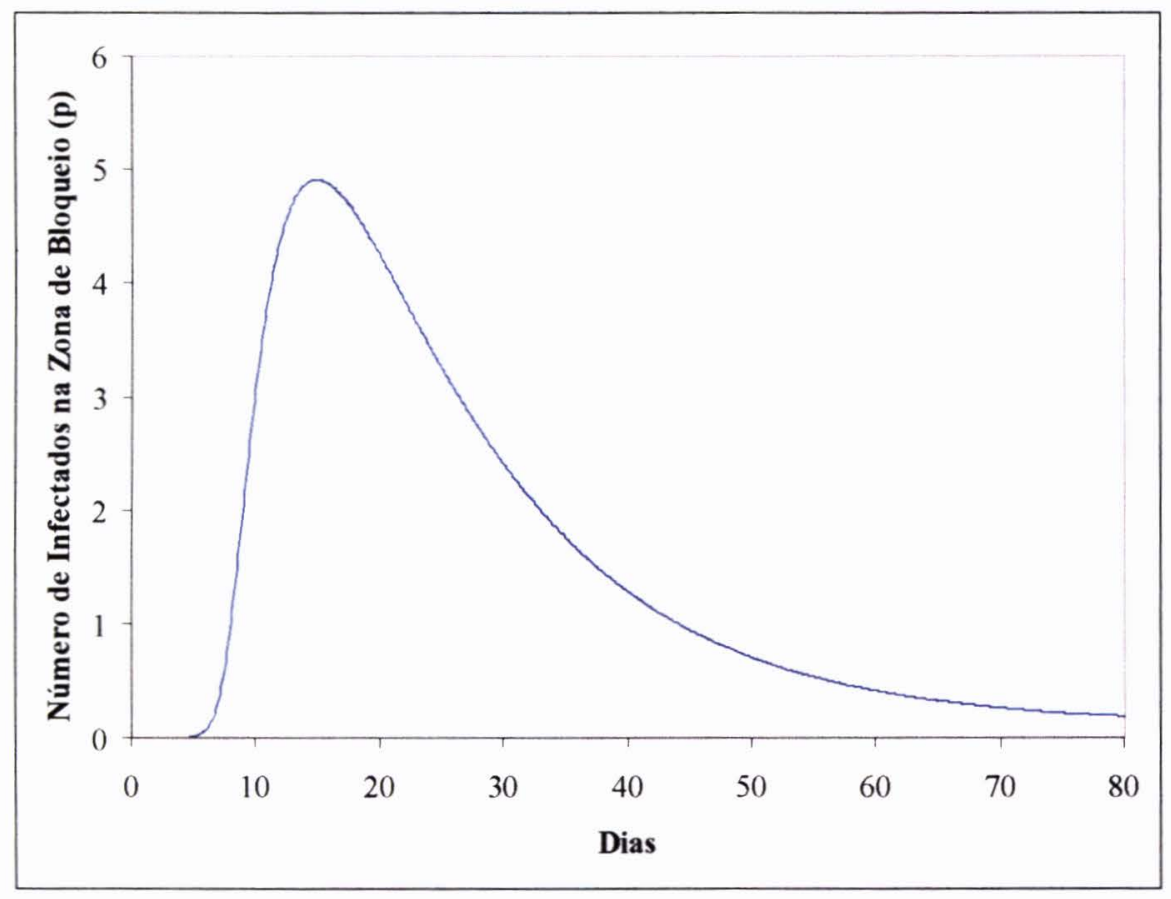

Figura 6 Evolução do número de infectados no interior da zona de bloqueio em função do tempo. A contagem do tempo iniciase quando a frente de onda atinge $o$ bloqueio 


\section{Epidemia de 1990 em Santa Catarina}

A epidemia de Febre Aftosa em Santa Catarina teve início em 22 de outubro de 1990 com a notificação de existência de foco de Febre Aftosa no município de Taió sendo o vírus identificado como pertencente ao subtipo C3 Indaial. O inquérito epidemiológico conduzido pelas autoridades de defesa animal daquele estado permitiu concluir que a doença havia surgido em 16 de outubro do mesmo ano. $O$ mesmo inquérito sugere que o vírus teria sido introduzido no estado através de um caminhão que transportava bovinos oriundos do estado do Rio Grande do Sul (OLIVEIRA e col., 1992). A epidemia se estendeu de 22/10/90 a 5/7/91 produzindo 132 focos no ano de 1990 e 206 em 1991 afetando praticamente todo o estado Figura 7. Os dados brutos são apresentados no Anexo B

Os dados da epidemia foram utilizados para a validação do modelo matemático apresentado anteriormente. 


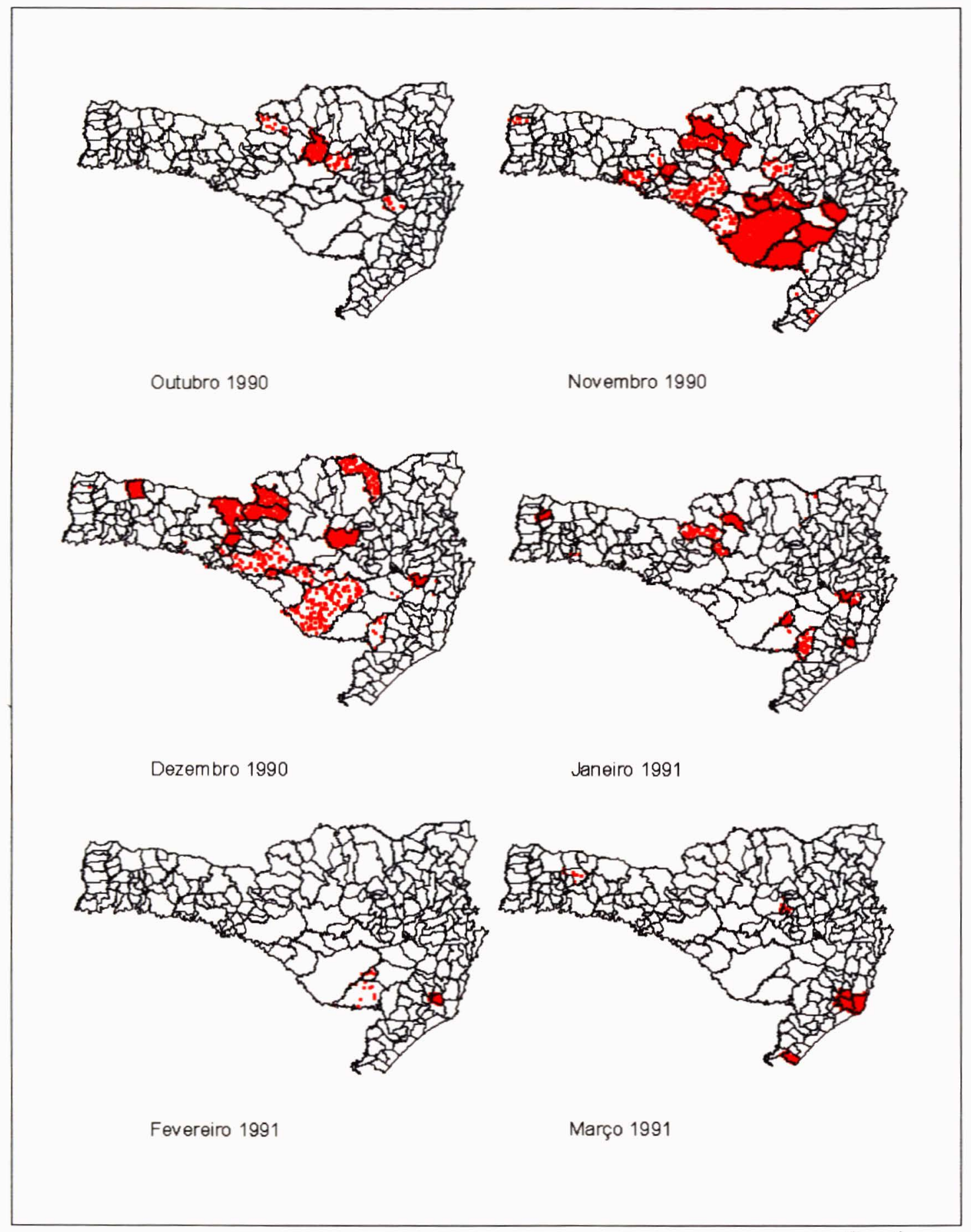

Continua 


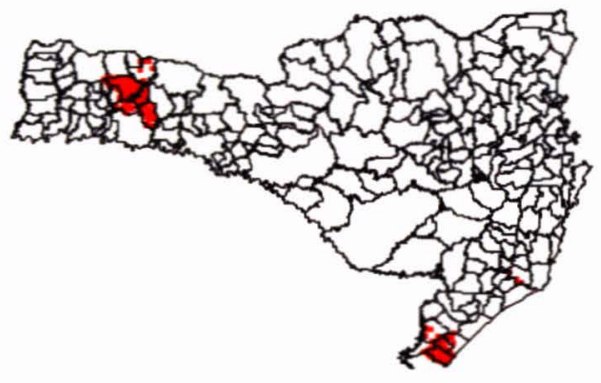

Abril 1991

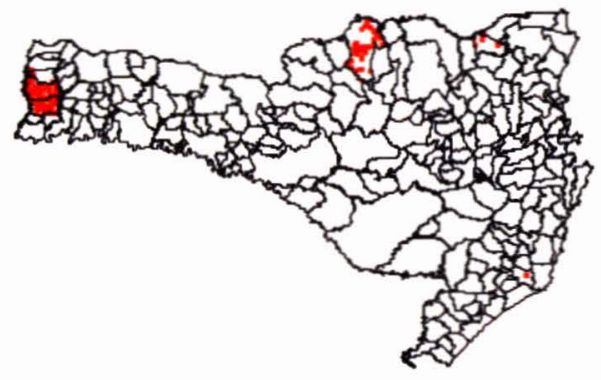

Junho 1991

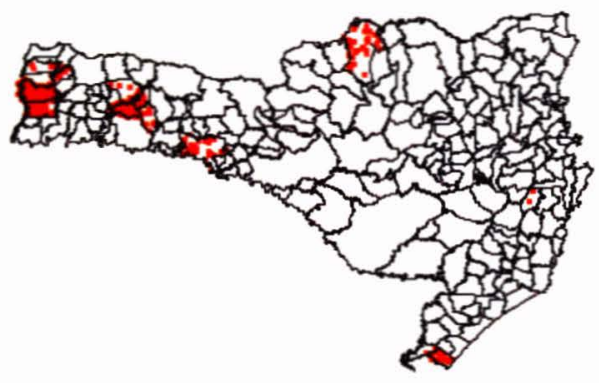

Maio 1991

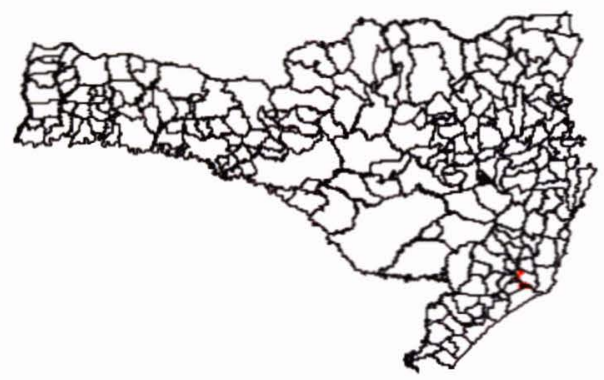

Julho 1991

Figura 7 Mapas do Estado de Santa Catarina representando a evolução mensal da epidemia de Febre Aftosa no período de outubro de 1990 a julho de 1991. Cada ponto representa um caso e os pontos estão distribuídos aleatoriamente dentro de cada município. 


\section{Programas de Computador Utilizados}

Para a criação dos mapas temáticos do Estado de Santa Catarina utilizou-se o programa comercial Arcliew GIS ${ }^{\mathbb{R}}$ versão 3.1 (Environmental System Research Institute, Inc - ESRI).

A geração de imagem em mapa de bits (imagem raster) para a realização das simulações foi feita com auxilio da extensão Spatial Analyst ${ }^{\mathrm{B}}$ para o ArcView GIS $^{\mathrm{B}}$. As imagens foram exportadas em formato ASCII, com auxilio do programa S-Plus ${ }^{(B)}$ versão 4.5 (Mathsoft, Inc.) e sua extensão S-Plus for Arcliew $G I^{{ }^{\mathbb{R}}}$, e utilizadas nas simulações. Os resultados das simulações foram importados e mapeados no ArcView $G I S^{\text {RR }}$. A reconstrução em três dimensões das simulações foi realizado com auxilio do programa Mathcad ${ }^{\mathbb{R}}$ versão 8.0 (Mathsoft, Inc.)

O programa para realizar as simulações foi desenvolvido em linguagem $\mathrm{C}$ utilizando os métodos de Runge-Kutta de quarta ordem para solução das equações diferenciais e, em relação à difusão, foi utilizado o método de direções alternantes implicitas (PRESS e col., 1992). As simulações foram executadas num microcomputador com dois processadores Pentium III 450Mhz rodando sistema operacional Linux.

A referência aos programas comerciais não significa qualquer aval ou preferência em relação a outros disponiveis no mercado, a utilização dos mesmos ocorreu exclusivamente em virtude de sua disponibilidade no Laboratório de Epidemiologia e Bioestatística da FMVZ - USP 


\section{Resultados}

\section{Estimativa dos Parâmetros a e b}

A estimativa do parâmetro $a$ foi realizada com base em dados fornecidos por OLIVEIRA e col (1992). Esses dados foram ajustados a um modelo exponencial conforme descrito em Material e Método. De acordo com OLIVEIRA e col (1992) nasceram em 1992531.785 animais, considerando-se a população no mesmo ano como sendo igual a 2.835.974 estimou-se através do modelo exponencial o valor de $a$ como sendo igual a $a=47,1 \times 10^{5} \mathrm{dia}^{-1}$. O valor de $b$ pode ser estimado como sendo o inverso da expectativa média de vida, ou seja, $b=39,1 \times 10^{5} \mathrm{dia}^{-1}$, conforme descrito em Material e Método.

\section{Estimativa do Parâmetro K}

A capacidade suporte do meio $(K)$ foi estimada considerando-se que a população bovina no Estado de Santa Catarina no período de 1972 a 1991 estava estável ( Figura 1) e que a densidade média no periodo representa o valor de $\mathrm{K}$. $\mathrm{Na}$ ecologia, a capacidade suporte do meio é condicionada por fatores tais como disponibilidade de alimento, presença de predadores, etc. No caso de criações, a mesma é determinada pela ação do homem através das práticas de criação da região. Assim, os dados produzidos por MARTINS e col. (1992) fornecem uma população média para o periodo igual a 2188835 animais. Sendo a área de Santa Catarina igual a $95442,9 \mathrm{~km}^{2}$ obtém-se para $\mathrm{K}$ o valor de 22,93 animais $\times \mathrm{km}^{-2}$.

Para a simulação em duas dimensões considerou-se a capacidade suporte como sendo heterogênea no estado. Assim, a estimativa de valores para a capacidade 
suporte foi realizada para cada municipio adotando-se a densidade populacional do municipio como valor da capacidade suporte. Isso significa considerar que a população bovina está em equilíbrio com densidade igual a capacidade suporte que é condicionada pelas práticas produtivas da região

\section{Estimativa do Parâmetro $\beta$}

O valor de $\beta$ foi estimado considerando-se a equação ( 7 ), os valores de $\alpha$ e $\delta$ apresentados na Quadro 2 e os valores de $a$ e $\mathrm{K}$ estimados anteriormente. A proporção de individuos suscetiveis no equilibrio $\left(\mathrm{S}^{*}\right)$ foi estimada considerando-se a série histórica de casos de febre aftosa fornecida por OLIVEIRA e col (1992) e apresentada na Figura 8. Estes dados informam que no período de 1971 a 1979 a prevalência de febre aftosa estava razoavelmente estável sugerindo que a doença estava próxima do equilibrio. Apesar de haver, nesse período, uma campanha de vacinação em andamento, a mesma não produziu uma imunidade de rebanho suficiente para impedir a transmissão da doença na população. Nessas condições, a relação entre a proporção de suscetiveis e o valor de $R_{0}$ se mantém válida e, conseqüentemente, a relação estabelecida pela equação ( 7 ) ( ANDERSON e MAY, 1991)

Para cada ano calculou-se a proporção de individuos suscetiveis como sendo igual a diferença "1-proporção de individuos não suscetiveis". Sendo que a proporção de individuos não suscetiveis é aproximada pela soma dos individuos vacinados e doentes dividida pela população bovina total. Assim, o cálculo da proporção de individuos suscetiveis na população para cada ano permitiu determinar 
o valor médio para o período como sendo igual a $S^{*}=0,0675$. Desse modo, obteve-se o valor $\beta=6,62 \times 10^{-2} \mathrm{~km}^{2} \times \mathrm{dia}^{-1}$.

Utilizando este valor de $\beta$ e aplicando-o na equação ( 6 ) pode-se calcular o valor de $\mathrm{R}_{0}$ obtendo $\mathrm{R}_{0} \cong 15$.

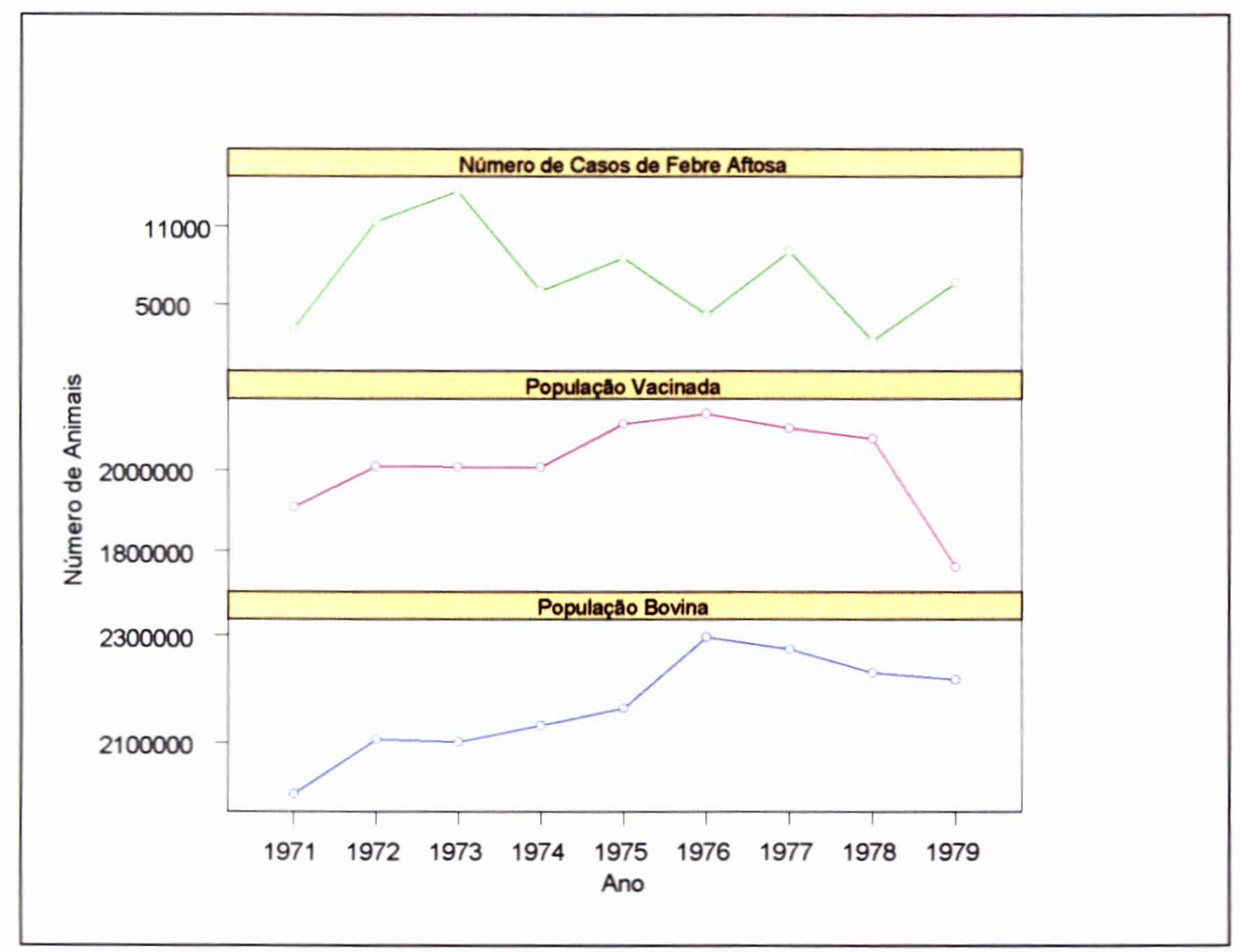

Figura 8 Número de casos de febre aftosa, população bovina vacinada e população bovina total do Estado de Santa Catarina, no período entre 1971 e 1979.

\section{Estimativa do Coeficiente de Difusão D}

O coeficiente de difusão foi estimado considerando-se o tamanho das propriedades rurais no Estado de Santa Catarina. A Tabela 1 apresenta a proporção de propriedades rurais segundo as diferentes categorias de tamanho permitindo estimar o tamanho mediano das mesmas como sendo igual a 31,92 ha, ou seja, $0,3192 \mathrm{~km}^{2}$. Considerou-se que um animal infectado é capaz de percorrer essa área 
em 1 dia. Assim estimou-se o coeficiente de difusão como sendo igual a $D=0,3192$ $\mathrm{km}^{2} / \mathrm{dia}$

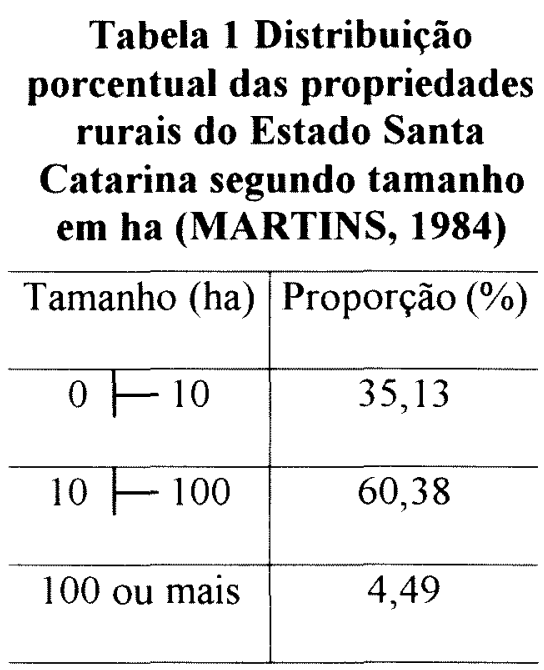

\section{Estimativa da Velocidade de Propagação da Epidemia}

A estimativa da velocidade de propagação da epidemia pode ser obtida através do tratamento matemático do conjunto de equações apresentadas em ( 4 ).

Assim, substituindo-se os valores das constantes nas equações apresentadas em ( 4 ) determinou-se que o sistema admite três pontos de equilíbrio quando $D=0$ para $(S, I, R)$ não negativos: $(0 ; 0 ; 0),(22,93 ; 0 ; 0)$ e $(1,54 ; 0,23 ; 8,55)$.

O mesmo sistema pode ser reescrito de modo adimensional estabelecendo-se que:

( 10$)$

$$
s=\frac{S}{K}, i=\frac{I}{K}, r=\frac{R}{K}, t=\beta K T,
$$

$$
x=\left(\frac{\beta K}{D}\right)^{\frac{1}{2}} \mathrm{X}, \varepsilon=\frac{(a-b)}{\beta K}, \mu=\frac{\gamma}{\beta K}, \rho=\frac{\delta}{\beta K}, \kappa=\frac{\alpha}{\beta K},
$$

de modo que o mesmo sistema pode ser representado da seguinte maneira: 


$$
\frac{\partial s}{\partial t}=(\varepsilon-a n-i) s+\mu r
$$

(11) $\quad \frac{\partial i}{\partial t}=(\varepsilon-\rho-\kappa-\boldsymbol{c n}+s)+\frac{\partial^{2} i}{\partial x^{2}}$

$$
\frac{\partial r}{\partial t}=(\varepsilon-\mu-\varepsilon n) r+\rho i
$$

Deseja-se em obter as soluções de ( 11 ) na forma de equação de onda epidêmica que viaje a uma velocidade constante $v \operatorname{logo}$, procura-se soluções $s, i$ e $r$ como função de uma única variável $\xi=x+v t$ que satisfaça:

$$
\begin{aligned}
& v s^{\prime}=(\varepsilon-i-a n) s+\mu r \\
& v i^{\prime}=(\varepsilon-\rho-\kappa-\varepsilon n+s) i+i^{\prime \prime} \\
& v r^{\prime}=(\varepsilon-\mu-a n) r+\rho i
\end{aligned}
$$

onde as derivadas são tomadas com relação a $\xi$ e $s \rightarrow 1, \mathrm{i} \rightarrow 0, \mathrm{r} \rightarrow 0$ quando $\xi \rightarrow-\infty$, isto é distante da frente de onda.

Substituindo-se os valores das constantes verifica-se que o sistema representado em ( 12 ) possui três possiveis soluções de equilibrio no primeiro quadrante ou seja, soluções não negativas, dadas por $(0 ; 0 ; 0),(1 ; 0 ; 0)$ e $\left(6,72 \times 10^{-2}\right.$, $\left.9,90 \times 10^{-3} ; 3,73 \times 10^{-1}\right)$ que são as mesmas soluções do sistema apresentado em ( 4 ) divididas por $\mathrm{K}$

A solução do sistema apresentado em ( 12 ) na forma de equação de onda que satisfaça as condições acima é uma trajetória no espaço de fase quadri-dimensional que vai do ponto $s=1, i=0$ e $r=0$ a um dos pontos $(0 ; 0 ; 0)$ ou $\left(6,72 \times 10^{-2} ; 9,90 \times 10^{-}\right.$ $\left.3,3,73 \times 10^{-1}\right)$.

Escrevendo o sistema ( 12 ) como um conjunto de equações diferenciais de primeira ordem tem-se: 


\section{( 13 )}

$$
s^{\prime}=\frac{(\varepsilon-i-a n) s+\mu r}{v}
$$

$$
i^{\prime}=w^{\prime}
$$

$$
\begin{aligned}
& r^{\prime}=\frac{(\varepsilon-\mu-\varepsilon n) r+\rho i}{v} \\
& w^{\prime}=w \mathbf{w}-(\varepsilon-\rho-\kappa-\varepsilon n+s) i
\end{aligned}
$$

Linearizando em torno do ponto crítico $\left(s, i, r, i^{\prime}\right)=(1,0,0,0)$ obtem-se um sistema cujas soluções são dadas pelas combinações lineares das autosoluções $x_{i} \exp \left(\lambda_{i} \xi\right)$ onde $x_{i}$ são os autovetores e $\lambda_{i}$ são os autovalores da matriz de estabilidade. Pode-se, então, determinar o comportamento do sistema próximo ao ponto crítico analisando as combinações possíveis das autosoluções, buscando trajetórias que deixem o ponto crítico $(1,0,0,0)$ quando $\xi \rightarrow \infty$. Estas soluções são dadas por combinações das autosoluções cujos autovalores sejam reais e maiores que zero, pois autovalores complexos levam a soluções oscilatórias e populações menores que zero, o que não é possível, e autovalores menores que zero produzem soluções que caminham em direção ao ponto de equilibrio $(1,0,0,0)$.

A linearização do sistema apresentado em ( 13 ) fornece um sistema cujos autovalores são dados por $\lambda=-\frac{\varepsilon}{v}<0$ e pelas raizes do seguinte polinômio:

$$
f(\lambda)=\lambda^{3}+\left(\frac{\mu}{v}-v\right) \lambda^{2}+(1-\mu-\kappa-\rho) \lambda+\frac{\mu}{v}(1-\kappa-\rho)
$$

A Figura 9 apresenta gráficos de $f(\lambda)$ para diferentes valores de velocidade. As autosoluções de interesse são aquelas cujos autovalores sejam reais e maiores que zero. Deseja-se identificar o valor da velocidade $\left(v_{c}\right)$ que separa as soluções de interesse, ou seja, o valor da velocidade para o qual a equação ( 14 ) apresenta uma 
raiz real dupla. Este valor pode ser determinado fazendo-se $f(\lambda)=0$ e $d f(\lambda) / d(\lambda)=0$ e eliminando-se $\lambda$. Esse processo permitiu estimar numericamente $v_{c}$ como sendo igual a 1,93. Esta é a velocidade mínima com que uma frente de onda de Febre Aftosa pode se propagar.

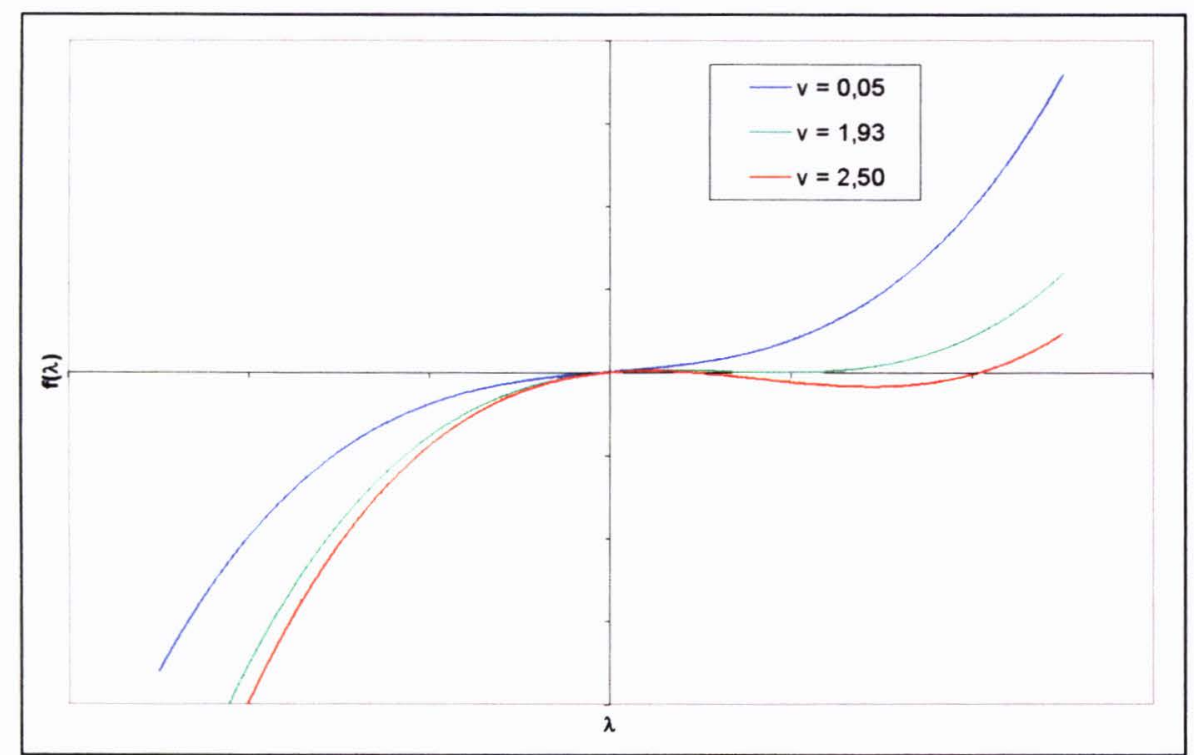

Figura 9 Autofunção $f(\lambda)$ para diferentes valores de velocidade

$\mathrm{Na}$ forma dimensional a velocidade mínima de propagação da onda é dada por $V=\sqrt{\beta D K} v$ o que permite calcular $V$ obtendo valor igual a $V=490.74 \mathrm{~km} / \mathrm{ano}$.

\section{Estimativa da Extensão da Zona de Bloqueio Vacinal}

O conjunto de equações apresentado em ( 4 ) foi simulado considerando-se a capacidade suporte fora da zona de bloqueio igual a apresentada em Material e Método. Para cada simulação fixou-se um valor para a capacidade suporte no interior da zona de bloqueio e para o número remanescente de animais infectados ( $p$ ) nessa região após um tempo crítico.

Cada simulação iniciava-se com a propagação da epidemia na zona anterior à zona de bloqueio, continuava após a entrada na mesma e era interrompida no 
momento em que restassem $p$ animais infectados no seu interior. Nesse instante o programa gerava um arquivo com o número de animais infectados para cada ponto da zona de bloqueio permitindo calcular sua extensão em função de $m$, ou seja, da proporção de animais infectados na sua extremidade distal em relação à extremidade proximal.

Nas simulações os valores de $\mathrm{K}$ variaram de 0,25 a 1,50 animais $/ \mathrm{km}^{2}$ e para $p$ foram utilizados os seguintes valores $0,20,0,60$ e 0,80 animais $/ \mathrm{km}$. Os resultados são apresentados na Figura 10.

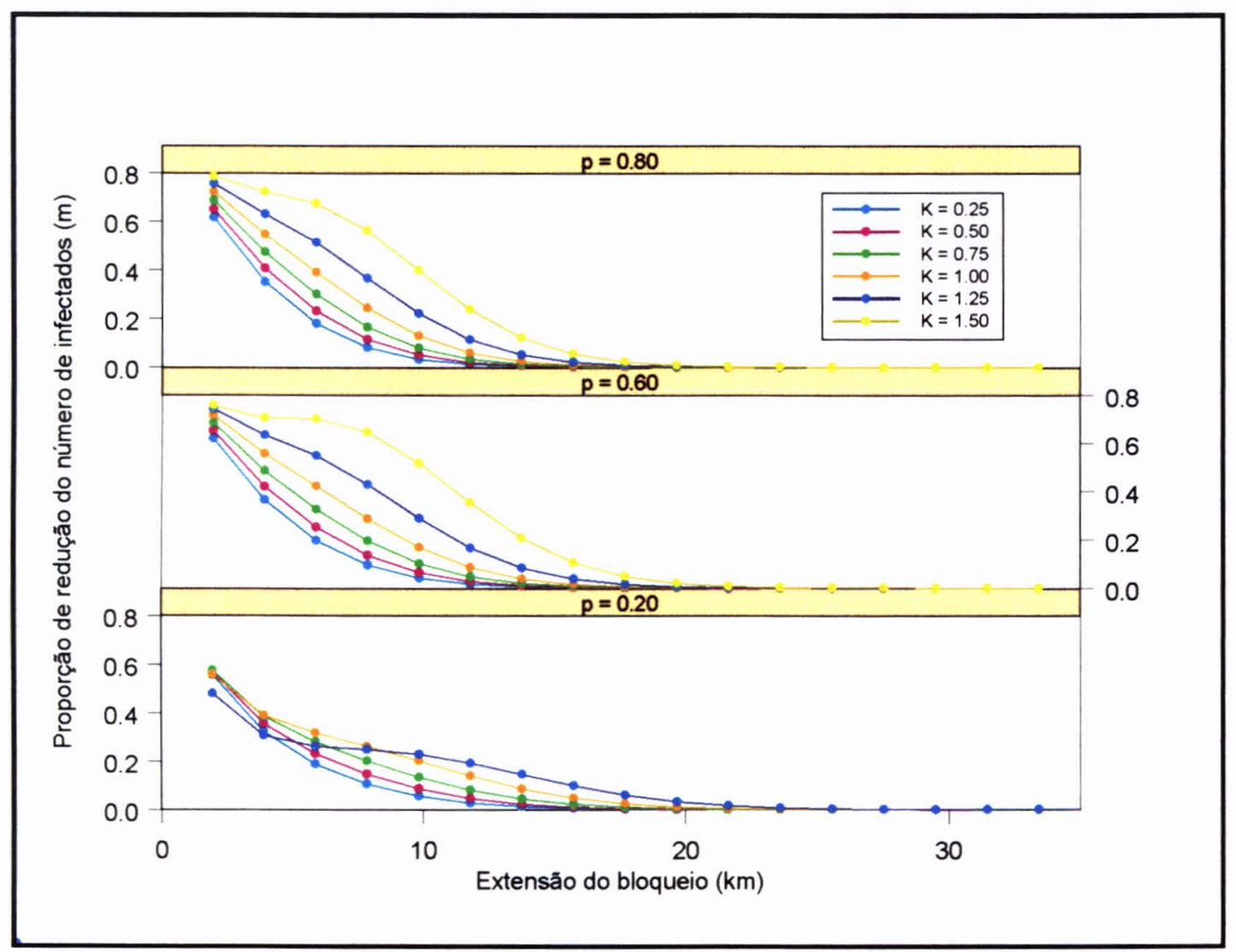

Figura 10 Extensão da zona de bloqueio vacinal em quilômetros como função de $m$, para $p$ variando de 0,20 a 0,80 animais $/ \mathrm{km}$ e capacidade suporte variando de 0,25 a 1,50 animais $/ \mathrm{km}^{2}$ 
Os resultados dessas simulações permitem determinar a probabilidade de que um animal infectado entre em contato com um animal suscetível a cada ponto da zona de bloqueio. Esses resultados são apresentados na Figura 11. A Figura 12 apresenta uma ampliação da figura anterior permitindo detalhar a relação entre a extensão da zona de bloqueio e probabilidades pequenas de encontro de um animal infectado com um suscetível. Essa informação pode ser utilizada para determinação da extensão da zona de bloqueio de maneira objetiva, que pode ser maior ou menor a critério das autoridades sanitárias.

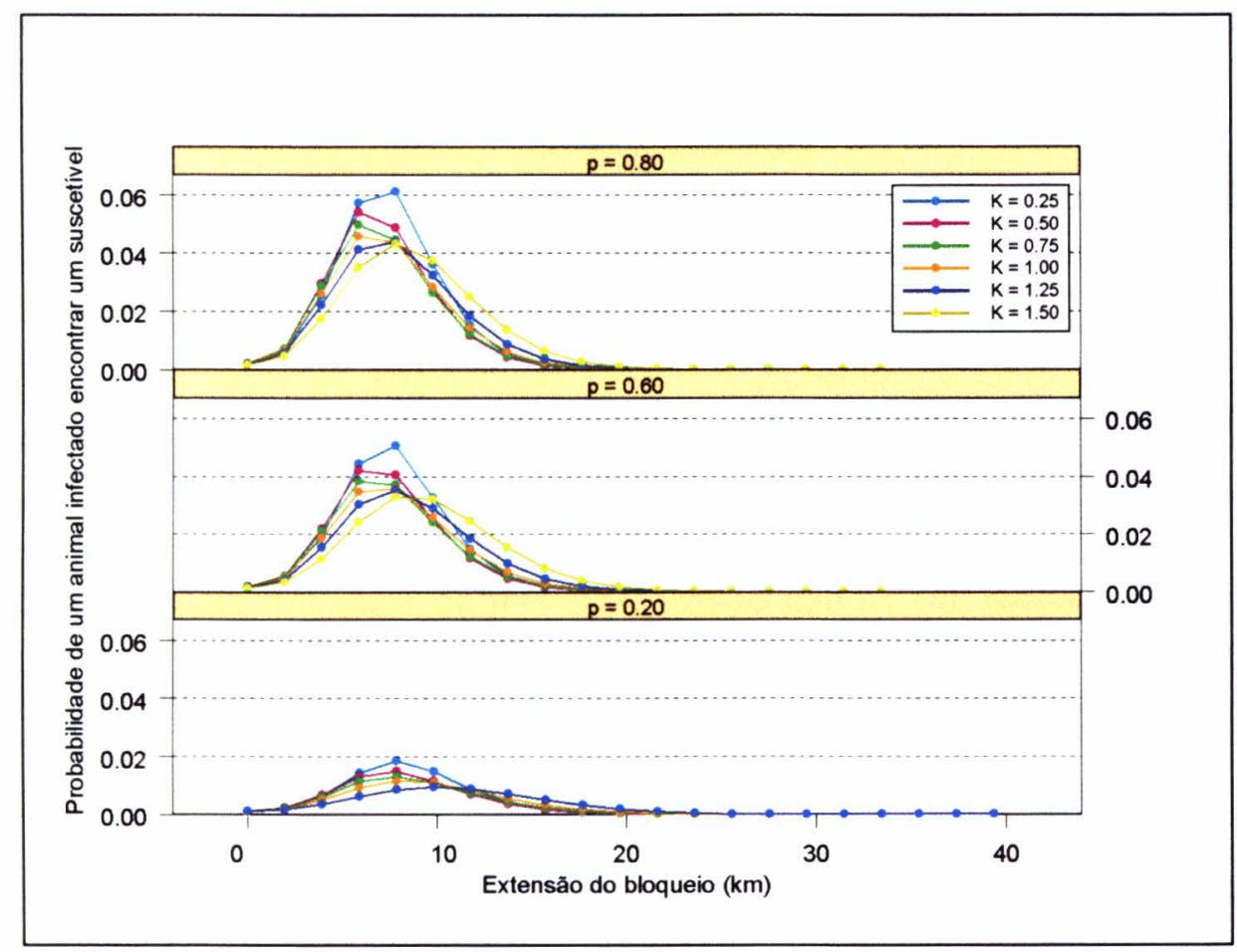

Figura 11 Distribuição das probabilidades de que um animal infectado encontre um animal suscetível segundo a posição na zona de bloqueio e redução da capacidade suporte nessa mesma zona 


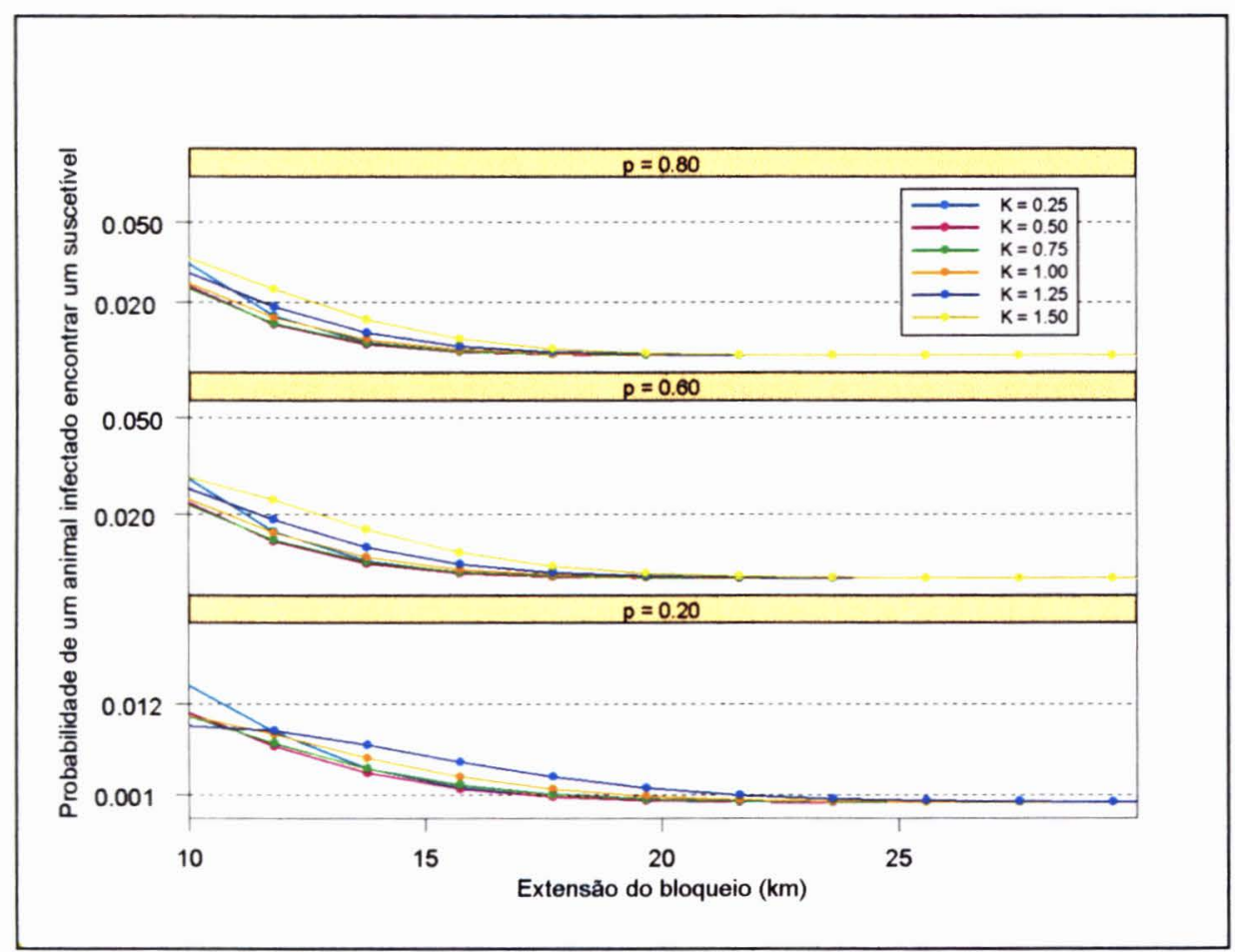

Figura 12 Ampliação da Figura 11, mostrando detalhes da região de probabilidade compreendida entre 0,00 e 0,05

Assim podemos observou-se que para uma redução na capacidade suporte a um valor igual a $\mathrm{K}=0,50$ animais $/ \mathrm{km}^{2}$, que representaria a imunização de $97,82 \%$ dos animais, e para um valor de $p=0,60$ tem-se que na extremidade protegida de uma zona de bloqueio com extensão de $15,73 \mathrm{~km}$ a probabilidade de um animal infectado encontrar um animal suscetivel é de 0,0015. Para uma extensão variando de 10 a $20 \mathrm{~km}$ essa probabilidade varia de 0,025 a 0,0001, permitindo a determinação dessa extensão conhecendo-se o risco de que um animal infectado possa eventualmente encontrar um suscetível.

\section{Validação do Modelo}

O conjunto de equações apresentados em ( 4 ) foi modificado substituindo-se o termo de difusão por $D \nabla^{2} I$, conforme apresentado em ( 15 ), de modo que o mesmo 
pudesse ser utilizado para simular numericamente a propagação de uma epidemia de Febre Aftosa no Estado de Santa Catarina com origem no município de Taió.

Para a simulação considerou-se o valor das constantes igual aos calculados anteriormente. Como condições iniciais considerou-se que a população era constituída inteiramente por indivíduos suscetíveis e que a mesma era igual a capacidade suporte do ambiente dada pela Figura 3. Apenas no município de Taió havia um foco de Febre Aftosa com dois animais $/ \mathrm{km}^{2}$. A exceção desse foco, a densidade de indivíduos infectados ou imunes no Estado foi considerada como sendo igual a zero.

Os resultados dessa simulação foram comparados com dados reais da epidemia de 1990 ocorrida no mesmo Estado sendo os resultados apresentados na Figura 13. Nesta figura temos os resultados das simulações associados a mapas de densidade de pontos que registram o número de casos de Febre Aftosa notificados durante a epidemia de 1990. Nele pode-se observar a concordância no tempo entre a posição da frente de onda epidêmica e a notificação de casos de Aftosa.

$$
\begin{aligned}
& \frac{\partial S}{\partial T}=a S-\left[b+(a-b) \frac{N}{K}\right] S-\beta S I+\gamma R \\
& \frac{\partial I}{\partial T}=(a-\delta-\alpha) I-\left[b+(a-b) \frac{N}{K}\right] I+\beta S I+D \nabla^{2} I \\
& \frac{\partial R}{\partial T}=(a-\gamma) R-\left[b+(a-b) \frac{N}{K}\right] R+\delta I
\end{aligned}
$$

A Figura 14 apresenta a reconstrução em três dimensões da frente de onda epidêmica que, iniciando-se no município de Taió, percorre todo o Estado de Santa Catarina em aproximadamente seis meses. 

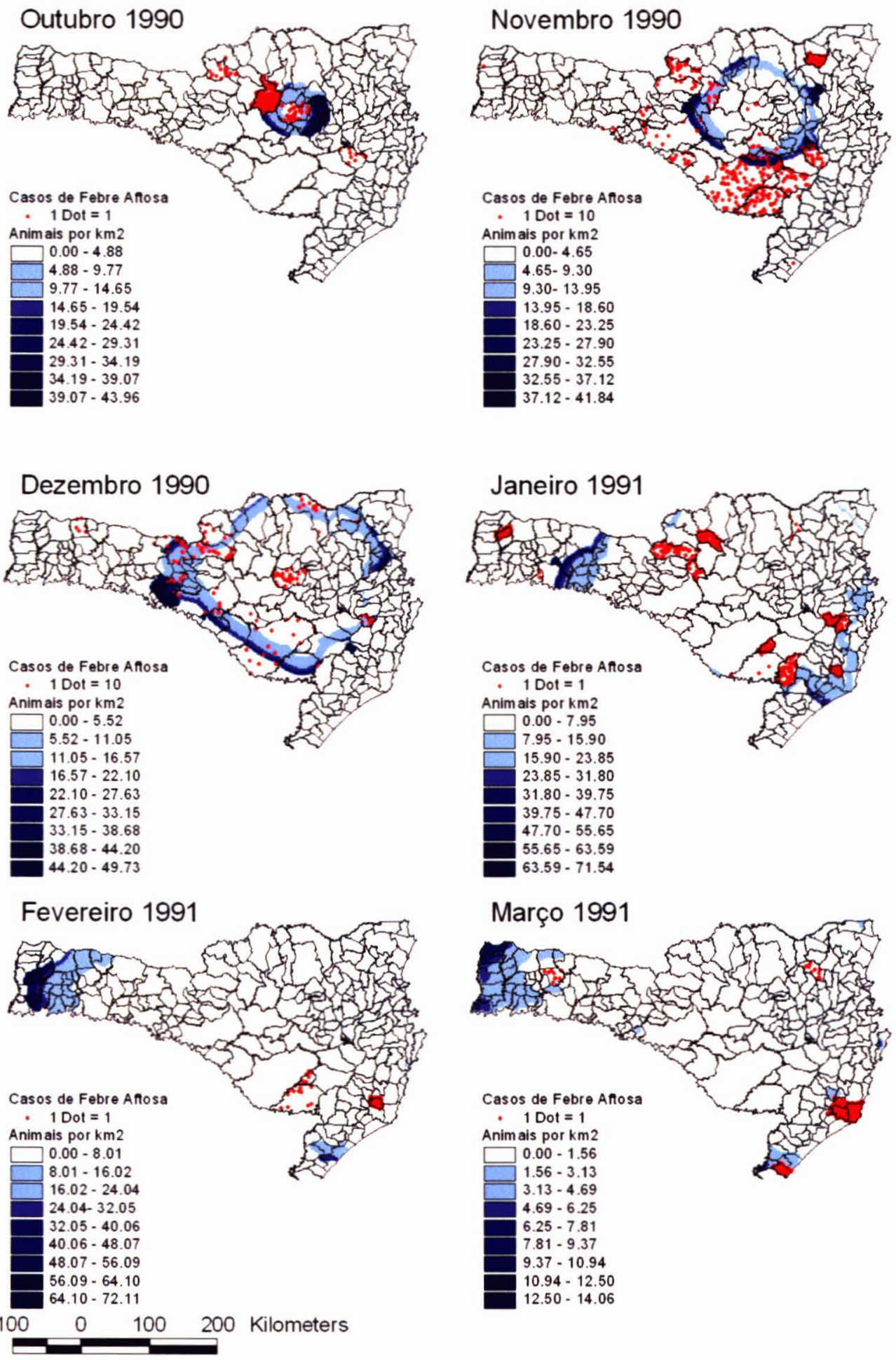

Continua 

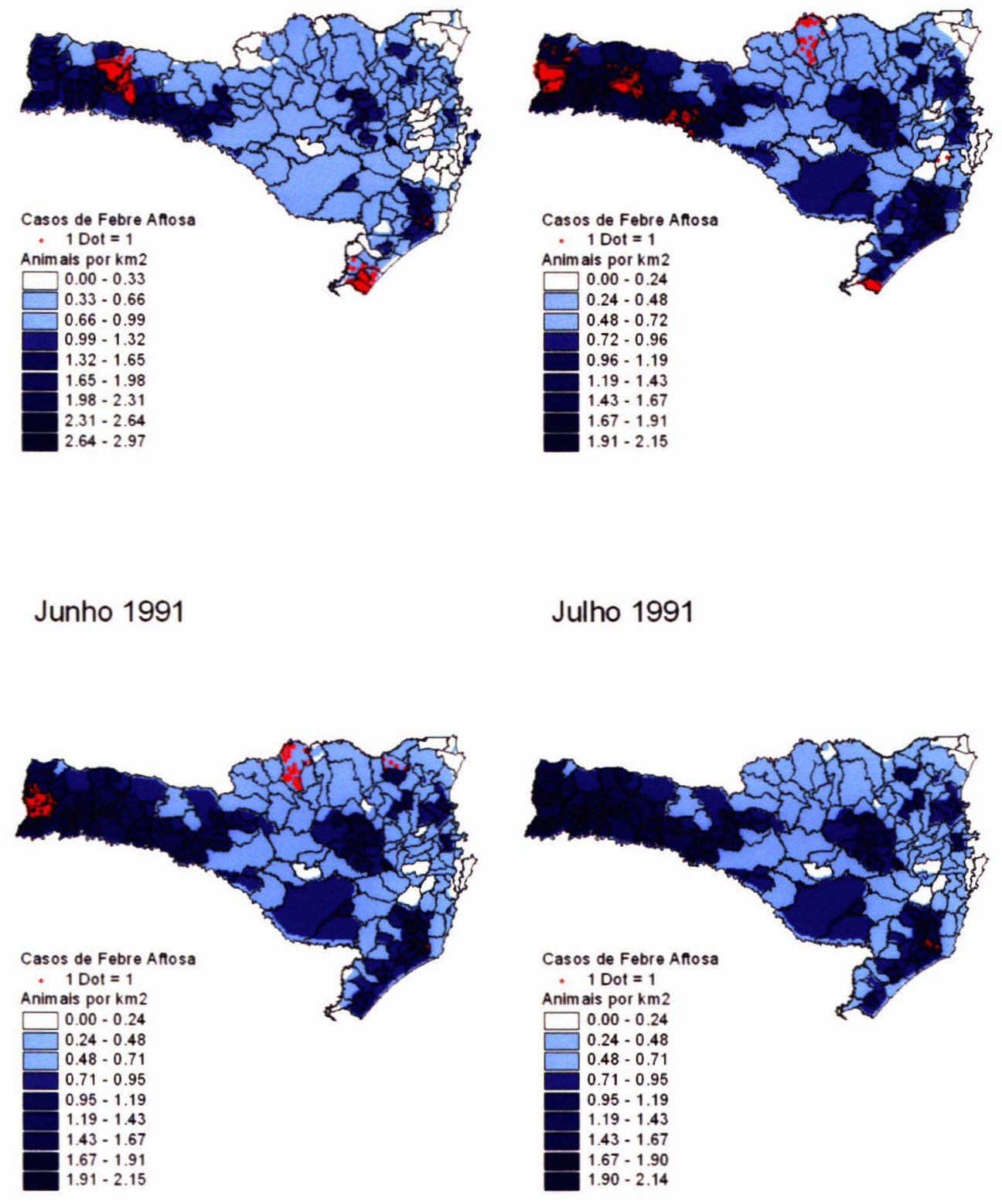

Figura 13 Mapas mensais de densidade de pontos mostrando a evolução da epidemia de Febre Aftosa no Estado de Santa Catarina associado a propagação da onda epidêmica resultante de simulação em duas dimensões do conjunto de equações apresentado em ( 15 ) 


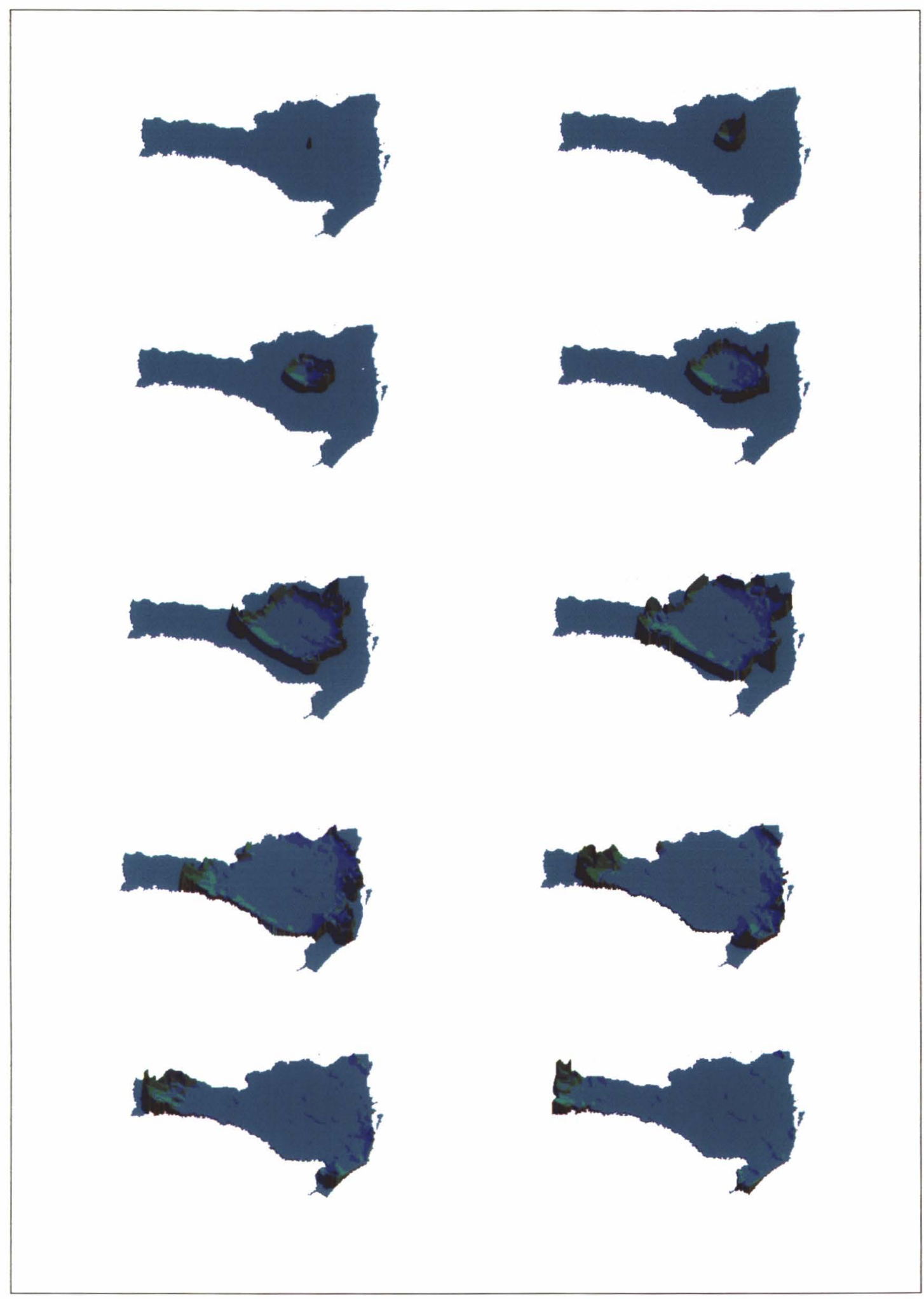

Figura 14 Reconstrução em três dimensões da propagação da frente de onda epidêmica calculada através da simulação do conjunto de equações apresentadas em ( 15 ). $O$ intervalo de tempo transcorrido entre dois mapas consecutivos é de 15 dias 
Uma vez validado o modelo e com a finalidade de ilustrar a capacidade do mesmo de simular intervenções repetiu-se a simulação em duas dimensões promovendo-se, desta vez, a vacinação de $97,82 \%$ dos suscetíveis num anel com extensão de $20 \mathrm{~km}$ situado $50 \mathrm{~km}$ à frente do foco inicial de Febre Aftosa (Municipio de Taió), de acordo com os resultados obtidos acima. Os resultados da simulação são apresentados na Figura 15. Nela pode-se observar que a onda epidêmica caminha até encontrar a zona de bloqueio, penetra na mesma produzindo, entretanto, um menor número de casos da doença sendo que não se observa o ressurgimento da epidemia na outra extremidade do bloqueio. Verifica-se, assim, que este anel é suficiente para conter a propagação da doença. 


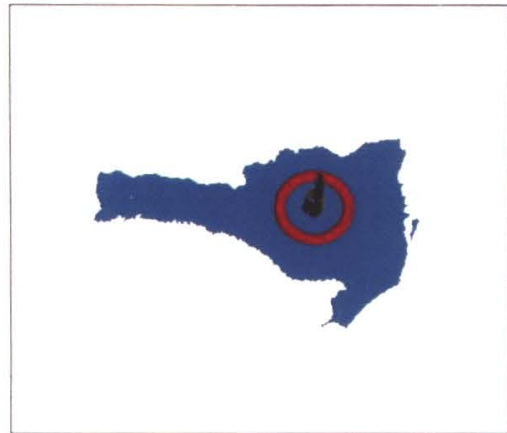

Dia 10

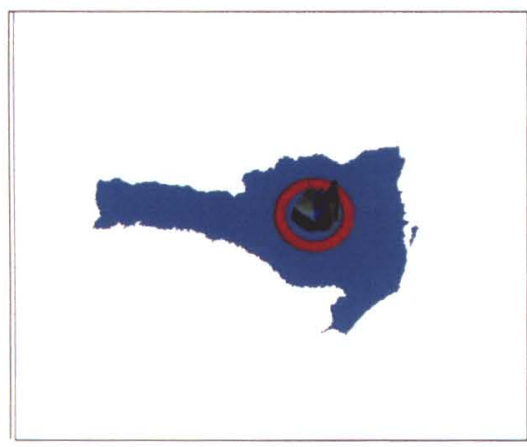

Dia 20

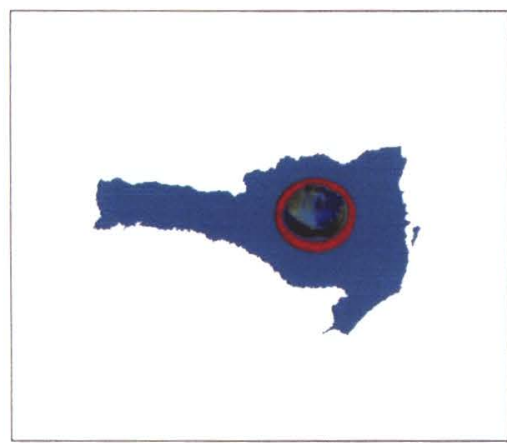

Dia 30

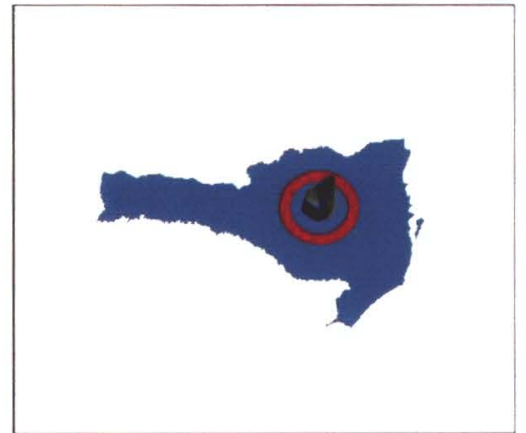

Dia 15

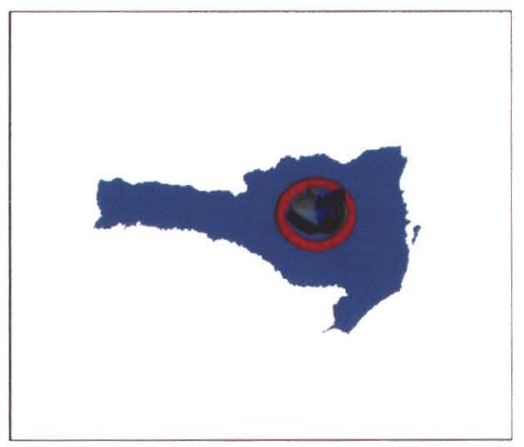

Dia 25

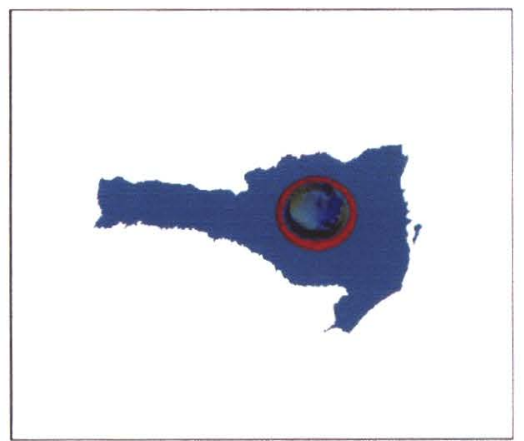

Dia 35

Figura 15 Simulação do impacto da vacinação realizada $50 \mathrm{~km}$ à frente do foco inicial de Febre Aftosa de $\mathbf{9 7 , 8 2 \%}$ dos bovinos suscetíveis num anel com $20 \mathrm{~km}$ de extensão (zona em vermelho) 


\section{Discussão}

O controle da Febre Aftosa nos estados brasileiros tem desviado o foco de atenção das ações de controle para as ações de vigilância, principalmente quando o programa passa para a etapa de suspensão da vacinação

Por um lado, a suspensão da vacinação representa a possibilidade de exportação para mercados consumidores representados pelos EUA, Japão e Europa e, por outro, cria uma população de milhões de animais suscetiveis

Esse é o momento pelo qual passam os Estados de Santa Catarina e Rio Grande do Sul. Nessa situação é necessário intensificar o controle sobre o trânsito de animais e de produtos de origem animal. Adicione-se a isso a necessidade de uma intensa atividade de vigilância de fronteiras entre regiões ou paises com diferentes situações sanitárias (no que tange o controle da Febre Aftosa).

Nesse cenário, é fundamental desenvolver-se planos de ação para emergências causadas pela introdução de virus nessa população. Nesse sentido o modelo proposto permite, através de simulações em computadores, antecipar com boa precisão a evolução da doença no tempo, bem como o padrão de dispersão espacial dos casos possibilitando avaliar o impacto de diferentes ações de controle de modo comparativo. O planejamento das ações passa a ocorrer com base em informações objetivas.

O modelo faz algumas pressuposições com o objetivo de torna-lo simples, sob a ótica da matemática envolvida mantendo, entretanto, as características fundamentais responsáveis pelo padrão de dispersão espaço-temporal da doença em populações bovinas 
Assim, não foi considerada a existência do estado de portador nos bovinos uma vez que há evidências na literatura (WOODBURY, 1995) de que essa condição tem pouco impacto na manutenção da doença na população. Exceção deve ser feita quando o portador é constituído por animais silvestres como o búfalo africano (HEDGER e col., 1985; DAWE e col., 1994). Esse, entretanto, não é o caso de Santa Catarina.

Do mesmo modo não foi considerada a transmissão por fồmites $\mathrm{e}$ por correntes de ar a longa distância dada a importância menor desses mecanismos quando comparados com o mecanismo principal de transmissão durante uma epidemia, que é o contato direto entre animais suscetíveis e infectados. Com relação a transmissão por correntes de ar a longa distância, GLOSTER e col.. (1982) esclarecem que essa possibilidade é bastante rara, ocorrendo somente quando há uma conjunção de grande quantidade de fatores favoráveis.

As taxas de natalidade, mortalidade, o coeficiente de transmissão e o coeficiente de difusão foram estimados com base em dados populacionais do rebanho de Santa Catarina, sendo que uma referência especial deve ser feita ao modo de estimar o coeficiente de difusão, uma vez que não há metodologia bem estabelecida para esse fim

Também não foi incorporado o sistema viário existente, pois o mesmo é importante somente na introdução de animais infectados em populações livres, desencadeando o início de epidemias que, uma vez iniciadas, se mantêm, principalmente, pelo contato entre infectados e suscetiveis. Some-se a isso o fato de que iniciada a epidemia, há o controle intenso das autoridades sanitárias sobre o trânsito de animais, o que reduz o seu impacto na dispersão da doença. 
As aproximações obtidas bem como as simplificações realizadas no modelo mostraram-se bastante razoáveis o que pode ser evidenciado pela concordância entre os resultados obtidos na simulação e os focos de febre aftosa produzidos pela epidemia de 1990 em Santa Catarina.

A vantagem da modelagem matemática de um fenômeno biológico reside no fato de que a linguagem matemática permite manipulação das equações favorecendo a obtenção de informações que de outra maneira seriam muito dificeis de serem conhecidas. Uma vez comprovado que o modelo representa adequadamente a epidemia de Febre Aftosa em bovinos, pode-se determinar a velocidade mínima de propagação da mesma, obtendo-se para esta o valor de $490,74 \mathrm{~km} / \mathrm{ano}$ o que representa aproximadamente $1,3 \mathrm{~km} / \mathrm{dia}$. Esse valor é bastante razoável considerando-se que no meio rural catarinense, essa é a distância entre duas ou três propriedades, o que equivaleria dizer que se hoje a doença está numa propriedade, no dia seguinte estaria na propriedade do vizinho.

O cálculo dessa velocidade se reveste de maior importância ao considerar a estruturação de um sistema de vigilância e de planos de contingência a serem aplicados em emergências produzidas pela introdução de Febre Aftosa em zonas nas quais não mais se vacinam os animais. Desta forma, sabe-se de antemão quanto a epidemia caminha a cada dia e qual é o aumento diário do número de casos, podendo-se, assim, estimar o impacto na produção provocado pelo retardo na notificação e no desencadeamento das ações de controle. Isso fornece, ainda, subsídios para o cálculo da magnitude dos prejuizos econômicos produzidos.

Em adição à determinação da velocidade mínima de propagação da epidemia, o modelo permitiu estimar de maneira objetiva a extensão de uma zona de bloqueio 
vacinal a ser criada de modo a impedir a propagação da frente de onda epidêmica. $\mathrm{O}$ cálculo da extensão dessa zona está baseado na probabilidade de contato entre um animal suscetivel e um infectado que está condicionada à magnitude da redução na densidade de suscetiveis produzida na zona de bloqueio, cabendo a autoridade sanitária a sua determinação assumindo um risco conhecido e desprezivel de que tal contato ocorra

Assim sendo, para o caso da epidemia de 1990 em Santa Catarina, pode-se determinar que para uma zona de bloqueio com extensão de aproximadamente $20 \mathrm{~km}$ na qual $97,82 \%$ dos animais estão protegidos, a probabilidade de contato entre um suscetivel e um infectado na extremidade distal da zona é 0,0001 .

Cumpre destacar que para a extensão preconizada pelo Ministério de Agricultura e do Abastecimento a probabilidade de tal contato, nas mesmas condições acima, é de 0,025 , ou seja, 250 vezes a probabilidade anterior. A falta de confiança nestes parâmetros estabelecidos sem metodologia científica pode ser evidenciada no caso do estado Mato Grosso do Sul que diante de foco de Febre Aftosa determina uma zona de bloqueio com extensão de $25 \mathrm{~km}$ ( $15 \mathrm{~km}$ a mais que o preconizado pelo Ministerio)

O modelo apresentou-se adequado para simular a propagação no tempo e no espaço de epidemias de Febre Aftosa em populações bovinas, bem como para estimar parâmetros úteis no planejamento de ações de controle da doença. Nesse sentido, abre-se a perspectiva de que o mesmo seja utilizado de rotina pelas autoridades sanitárias dos diferentes estados ou mesmo pelo Ministério da Agricultura e Abastecimento com o objetivo de simular intervenções antecipando o 
resultado das diferentes ações como demonstrado pela Figura 15. Isto representaria economia de tempo e recursos no combate a epidemias de Febre Aftosa no país.

Em relação à simulação de intervenções deve-se destacar que, de acordo com o referido em Material e Método, será sempre possivel que em uma simulação a epidemia ultrapasse a zona de bloqueio vacinal em virtude do modelo assumir as populações como sendo contínuas no tempo e espaço e por utilizar as equações de difusão. Assim, apesar do modelo representar a dinâmica espacial da doença adequadamente, ele não deve ser utilizado para determinar a extensão da zona de bloqueio vacinal necessário para bloquear a propagação da epidemia. Para isto devese utilizar o método baseado em probabilidades como descrito anteriormente.

A utilização desse modelo por instituições governamentais para realizar simulações de intervenções poderá ser facilitada com o desenvolvimento futuro de um software para esta finalidade. Dessa maneira, o planejamento das ações de controle passaria a incorporar instrumentos modernos e metodologia científica em áreas onde a "experiência de campo", respeitável, porém imprecisa, tem tradicionalmente desempenhado papel de destaque 


\section{Conclusões}

- Pode-se determinar o coeficiente de transmissão obtendo-se valor igual a $\beta=6,62 \times 10^{-2} \mathrm{~km}^{2} \times \mathrm{dia}^{-1}$

- Para o coeficiente de difusão obteve-se o valor $D=0,3192 \mathrm{~km}^{2} \times \mathrm{dia}^{-1}$.

- A velocidade mínima de propagação de uma epidemia de Febre Aftosa no Estado de Santa Catarina é de $V=490,74 \mathrm{~km} \times \mathrm{ano}^{-1}$.

- A extensão da zona de bloqueio vacinal depende da densidade de suscetiveis presentes nessa área e pode ser determinada com base na probabilidade de que um animal infectado entre em contato com um animal suscetível, o que significa assumir risco conhecido de que isso aconteça. Considerando-se a presença de apenas $2,28 \%$ de suscetíveis nessa zona, a probabilidade de contato entre animais suscetiveis e infectados, para um valor de $p=0,60$ animal $/ \mathrm{km}$, varia de 0,025 a 0,0001 para uma extensão variando de 10 a 20 $\mathrm{km}$, respectivamente.

- O modelo foi capaz de simular adequadamente a difusão espacial da epidemia de Febre Aftosa ocorrida no Estado de Santa Catarina no ano de 1990 


\section{Referências Bibliográficas}

Anderson RM, Jackson HC, May RM, Smith AM. Population dynamics of fox rabies in Europe. Nature $1981 ; 289: 765-771$.

Anderson RM. The population dynamics of infectious diseases: theory and applications. London: Chapman and Hall; 1982.

Anderson RM, May RM. Infectious diseases of humans: dynamics and control. Oxford: Oxford University Press, 1991.

Astudillo VM. La fiebre aftosa en America del Sur. Hora Vet. 1992, 70:16-22.

Berentsen PMB, Dijkhuizen AA, Oskam AJ. A dynamic model for cost-benefit analyses of foot-and-mouth disease control strategies. Prev. Vet. Med. 1992, $12: 229-243$

Berentsen PMB, Dijkhuizen AA, Oskam AJ. A critique of published cost-benefit analyses of foot-and-mouth disease. Prev. Vet. Med. 1992a, 12:217-227.

Brooksby JB. Portraits of viruses: foot-and-mouth disease virus. Intervirology 1982, $18: 1-23$

Brown F, Cartwright B, Newman JFE. Further studies on the early antibodies in the sera of cattle and guinea pigs infected with FMDV. J. Immun. 1964, 93:397-402.

Burgi M. General prophylatic measures for FMD. Bull. Off. Int. Epiz. 1928, 1:537576.

Burrows R. Excretion of foot-and-moth disease virus prior to development of lesions. Vet. Rec. 1968, 82:387-388. 
Burrows R, Mann JA, Garland AJM, Greig A, Goodridge D. The pathogenesis of natural and simulated natural foot-and-mouth disease in cattle. J. Comp. Pathol. 1981, 91:599-609.

Burrows R, Mann JA, Greig A, Chapman WG, Goodrige D. The growth and persistence of foot-and-moth disease virus in the bovine mammary gland,. $\mathbf{J}$. Hyg. (Camb.) 1971, 69:307-321

Dawe PS, Sorensen K, Ferris NP, Barnett ITR, Armstrong RM, Knowles NJ. Experimental transmission of foot-and-mouth disease virus from carrier African buffalo (Syncerus caffer) to catlle in Zimbabwe. Vet. Rec. 1994, 139:211-215.

Fenner F, Backmann PA, Gibbs EPJ, Murphy FA, Studdert MJ, White DO. Virología Veterinaria. Zaragoza: Editorial Acribia; 1992.

Fogedby EG, Malmquist WA, Osteen OL, Johnson ML. Air-bone transmission of foot-and-mouth disease virus. Nord. Vet.-Med. 1960, 12:490-498.

Gloster J, Sellers RF, Donaldson AI. Long distance transport of foot-and-mouth disease virus over the sea. Vet. Record 1982, 110:47-52.

Hedger RS. The isolation and characterization of FMDV from clinically normal herds of cattle in Botswana. J. Hyg. (Camb.) 1968, 66:27-36.

Hedger RS. Foot-and-Mouth Disease. In: Davis J e col., editores. Infectious diseases of wild mammals. $2^{\text {nd }}$ ed. Iowa: Iowa State University Press; 1981.

Hedger RS, Condy JB. Transmission of foot-and-mouth disease from African buffalo virus carriers to bovines. Vet. Record 1985, 117: 205. 
Hyslop NStG. Airbone infection with the virus of foot-and mouth disease. J. Comp. Path. $1965,75(2): 119-127$.

Krystynak RHE, Charlebois PA. The potential economic impact of an outbreak of foot-and-mouth disease in Canada. Can. Vet. J. 1987, 28:523-527.

Martins C. Caracterização epidemiológica da Febre Aftosa no espaço catarinense. Minas Gerais; 1984. [Tese de Doutoramento - Escola de Veterinária da Universidade Federal de Minas Gerais].

Mann JA, Sellers RF. Foot-and-mouth disease virus. In: Dinter Z e Morein B, editors. Virus Infections of Ruminants. The Netherlands: Elsevier Science Publishers B. V.; 1990. p. 503-512 ( Virus Infections of Vertebrates, v.3 ).

Ministério da Agricultura. Manual de Procedimentos em Focos de Febre Aftosa Plano Nacional de Combate à Febre Aftosa. Brasilia, 1973.

Murray JD, Stanley EA, Brown DL. On the spatial spread of rabies among foxes. Proc. R. Soc. Lond. B 1986, 229:111-150.

Nielen M, Jalvingh AW, Horst HS, Dijkhuizen AA, Maurice H, Shut BH, van Wuijckhuise LA, de Jong MF. Quantification of contacts between Dutch farms to the potential risk of foot-and-mouth disease spread. Prev. Vet. Med. 1996, $28: 143-158$

Office International des Epizooties. International Animal Health Code Mammals, Birds and Bees. 6 ed. Paris: OIE, 1992.

Office International des Epizooties. Foot and mouth disease in Brazil in the State of Mato Grosso do Sul. Disease Information 1998, 11(11). 
Office International des Epizooties. Foot and mouth disease in Brazil. Additional information on the outbreaks in Mato Grosso do Sul. Disease Information 1998a, 11(12).

Olascoaga RC. Continental strategy in the fight against foot-and-mouth disease. Hora Vet. 1991, 62:51-61

Olitsky PK. Summary of observations of the commission to study foot-and-mouth disease. J. Am. Vet. Med. Ass. 1927, 70:926-955.

Oliveira JF, Kirinus LCC, Martins C. Relatório sobre Febre Aftosa. Florianópolis; 1992 [Relatório de atividades produzido pela Companhia Integrada de Desenvolvimento Agrícola de Santa Catarina (CIDASC) - Secretaria da Agricultura e Abastecimento].

Pereira HG. Fiebre Aftosa. In: Gibbs EPJ, editor. Enfermedades Viricas de Ios Animales de Abasto Zaragoza: Acribia; 1987. p. 3-35

Press WH, Teukolsky SA, Vetterling, WT, Flannery, BP. Numerical recipes in C: the art of scientific computing. $2^{\text {a }}$ ed. Cambridge: Cambridge University Press; 1992.

Ramon G. Carriers and vectors of microbial germs. Bull. Off. Int. Epiz. 1956, 45:818.

Sanson RL, Liberona H, Morris RS. The use of a geographical information system in the management of a foot-and-mouth disease epidemic. Prev. Vet. Med. 1991, $11: 309-313$ 
Tomson GR. Foot-and-mouth disease. In: Coetzer JAW, Thomson GR, Tustin RC, Kriek NPJ, editores. Infectious Diseases of Livestock. Cape Town: Oxford University Press; 1994, p.825-852.

Walker J. Some observations on foot-and-mouth disease in the Beachuanaland Protectoorate. J. South Afric. Vet. Med. Assoc. 1934, 5:73-91.

Woodbury EL. A review of the possible mechanisms for the persistence of foot-andmouth disease virus. Epidemiol. Infect. 1995, 114:1-13

Yu P, Habtemarian T, Wilson S, Oryang D, Nganwa D, Obasa M, Robnett V. A riskassessment model for foot and mouth disease (FMD) virus introduction through deboned beef importation. Prev. Vet. Med. 1997, 30:49-59. 


\section{Anexo A}

List of FMD free countries

\section{RESOLUTION NO. X}

Recognition of the foot and mouth disease status of Member Countries CONSIDERING THAT

1. During the 63rd General Session, the International Committee adopted Resolutions XI and XII, 'Establishment of a list of foot and mouth disease (EMD) free countries where vaccination is not practised', and 'Procedure for the recognition of the foot and mouth disease status of Member Countries',

2. During the 64 th General Session, the International Committee adopted Resolution XII which asks that the Director General publish in the Bulletin a list of the countries or zones within national territories that fulfil the criteria of one of the FMD free categories described in Chapter 2.1.1. of the International Animal Health Code,

3. The Foot and Mouth Disease and Other Epizootics Commission has continued to apply the procedure approved by the International Committee and has supported the recognition of the FMD free status of additional countries and zones within national territories for annual adoption of the list by the International Committee,

4. During the 65 th General Session, the International Committee adopted Resolution XII which stated that the Delegates of Member countries where countries or zones within their national territories are recognised as FMD free annually confirm by letter each November both their status and that the criteria by which their status was recognised remain the same,

5. During the 65 th General Session, the International Committee adopted Resolution XVII delegating to the Foot and Mouth Disease and other Epizootics Commission the authority to recognise, without further International Committee consultation, that a Member country or zone within its territory has regained its previously recognised FMD free status following outbreaks that are eradicated in accordance with the relevant provisions of Chapter 2.1 .1 of the International Animal Health Code,

6. Information published by the OIE is derived from declarations made by the official Veterinary services of Member Countries. The OIE is not responsible for inaccurate publication of country disease status based on inaccurate or incomplete information or changes in epidemiological status or other significant events that were not promptly reported to the Central Bureau subsequent to the time of declaration of freedom. 


\section{THE COMMITTEE}

\section{RESOLVES}

That the Director General publish in the Bulletin the following list of Member Countries recognised as FMD free countries where vaccination is not practised, according to the provisions of Chapter 2.1.1 of the International Animal Health Code ${ }^{2}$ :

$\begin{array}{llll}\text { Australia } & \text { Austria } & \text { Belgium } & \text { Bulgaria } \\ \text { Canada } & \text { Chile } & \text { Costa Rica } & \text { Croatia } \\ \text { Cuba } & \text { Cyprus } & \text { Czech Rep. } & \text { Denmark } \\ \text { El Salvador } & \text { Estonia } & \text { Finland } & \text { France } \\ \text { Germany } & \text { Greece } & \text { Haiti } & \text { Honduras } \\ \text { Hungary } & \text { Iceland } & \text { Indonesia } & \text { Ireland } \\ \text { Italy } & \text { Japan } & \text { Korea } & \text { Latvia } \\ \text { Lithuania } & \text { Luxemburg } & \text { Madagascar } & \text { Malta } \\ \text { Mexico } & \text { Netherlands } & \text { New Caledonia } & \text { New Zealand } \\ \text { Norway } & \text { Panama } & \text { Poland } & \text { Portugal } \\ \text { Romania } & \text { Singapore } & \text { Slovakia } & \text { Slovenia } \\ \text { Spain } & \text { Sweden } & \text { Switzerland } & \text { U. Kingdom } \\ \text { USA } & \text { Uruguay } & \text { Vanuatu } & \end{array}$

AND

That the Director General publish in the Bulletin the following Member

Countries as having an FMD free zone where vaccination is not practised, according to the provisions of Chapter 2.1 .1 of the International Animal Health Code:

Botswana ${ }^{2}$, Colombia ${ }^{3}$, Namibia $^{4}$ and South Africa ${ }^{5}$.

AND

That the Director General publish in the Bulletin the following Member country as having an FMD free zone where vaccination is practised, according to the provisions of Chapter 2.1 .1 of the International Animal Health Code:

Brazil

AND

That the Director General publish in the Bulletin the following Member countries as being FMD free countries where vaccination is practised, according to the provisions of Chapter 2.1.1 of the International Animal Health Code :

Argentina and Paraguay. 1998)

(Adopted by the International Committee of the OIE on 27 May 
(1) For information about the status of non-contiguous territories of Member Countries recognised as FMD free address enquiries to that country's Delegate or the Director General

(2) Zone designated by the Delegate of Botswana in documents addressed to the Director General on 26 August 1996 and 24 september 1997

(3) Zone designated by the Delegate of Colombia in documents addressed to the Director General on 25 November 1995 (Area I Northwest region of Choco Department) and 3 April 1996.

(4) Zone designated by the Delegate of Namibia in a document addressed to the Director General on 6 February 1997.

(5) Zone designated by the Delegate of South Africa in documents addressed to the Director General on 3 May and 18 December 1995.

(6) Zone designated by the Delegate of Brazil in documents addressed to the Director General on 17 September 1997 and 19 December 1997 , comprising the states of Rio Grande do Sul and Santa Catarina 


\section{Anexo B}

\begin{tabular}{|c|c|c|c|c|c|c|c|c|c|c|c|c|c|c|c|c|c|c|c|c|c|}
\hline \multirow{3}{*}{ Munictpio } & \multirow{3}{*}{ CTA } & \multicolumn{20}{|c|}{ Meses: } \\
\hline & & \multicolumn{2}{|c|}{ Out 90} & \multicolumn{2}{|c|}{ Nov 96} & \multicolumn{2}{|c|}{ Det 90} & \multicolumn{2}{|c|}{$\operatorname{Tan} 91$} & \multicolumn{2}{|c|}{ Tev91 } & \multicolumn{2}{|c|}{ Mar SI } & \multicolumn{2}{|c|}{$A b / 9 I$} & \multicolumn{2}{|c|}{ Mat 91} & \multicolumn{2}{|c|}{ fun 91} & \multicolumn{2}{|c|}{ Sul 91} \\
\hline & & Cason & Fooos & Casos & foos & Chsos & focas & Casos & Fooss & $\mathrm{C} 4 \mathrm{~s}$ & Fooos & Casos & Focas & Casas & focas & Casos & Focos & Casus & Focos & Casas & Tocos \\
\hline Abdon Batista & Campos Novos & 0 & 0 & 0 & 0 & 21 & 2 & 0 & 0 & 0 & 0 & 0 & 0 & 0 & 0 & 0 & 0 & 0 & 0 & 0 & 0 \\
\hline Abelardo Luz & Concórdia & 0 & 0 & 0 & 0 & 0 & 0 & 0 & 0 & 0 & 0 & 0 & 0 & 0 & 0 & 0 & 0 & 0 & 0 & 0 & 0 \\
\hline Agrinómica & Ituporanga & 0 & 0 & 0 & 0 & 0 & 0 & 0 & 0 & 0 & 0 & 0 & 0 & 0 & 0 & 0 & 0 & 0 & 0 & 0 & 0 \\
\hline Agrolândia & Ituporanga & 0 & 0 & 0 & 0 & 0 & 0 & 0 & 0 & 0 & 0 & 0 & 0 & 0 & 0 & 0 & 0 & 0 & 0 & 0 & 0 \\
\hline Água Doce & Campos Novos & 0 & 0 & 0 & 0 & 156 & 1 & 0 & 0 & 0 & 0 & 0 & 0 & 0 & 0 & 0 & 0 & 0 & 0 & 0 & 0 \\
\hline Águas de Chapecó & Chapecó & 0 & 0 & 0 & 0 & 0 & 0 & 0 & 0 & 0 & 0 & 0 & 0 & 0 & 0 & 0 & 0 & 0 & 0 & 0 & 0 \\
\hline Aguas Mornas & Florianópolis & 0 & 0 & 0 & 0 & 0 & 0 & 16 & 1 & 0 & 0 & 0 & 0 & 0 & 0 & 2 & 1 & 0 & 0 & 0 & 0 \\
\hline Alfredo Wagner & Ituporanga & 10 & 1 & 261 & 3 & 0 & 0 & 0 & 0 & 0 & 0 & 0 & 0 & 0 & 0 & 0 & 0 & 0 & 0 & 0 & 0 \\
\hline Anchieta & Chapecó & 0 & 0 & 0 & 0 & 0 & 0 & 81 & 5 & 0 & 0 & 0 & 0 & 0 & 0 & 8 & 1 & 0 & $1^{*}$ & 0 & 0 \\
\hline Angelina & Florianópolis & 0 & 0 & 0 & 0 & 0 & 0 & 0 & 0 & 0 & 0 & 0 & 0 & 0 & 0 & 0 & 0 & 0 & 0 & 0 & 0 \\
\hline Anita Garibaldi & Lages & 0 & 0 & 117 & 1 & 0 & 0 & 0 & 0 & 0 & 0 & 0 & 0 & 0 & 0 & 0 & 0 & 0 & 0 & 0 & 0 \\
\hline Anitápolis & Florianópolis & 0 & 0 & 0 & 0 & 0 & 0 & 0 & 0 & 0 & 0 & 0 & 0 & 0 & 0 & 0 & 0 & 0 & 0 & 0 & 0 \\
\hline Antônio Carlos & Florianópolis & 0 & 0 & 0 & 0 & 0 & 0 & 0 & 0 & 0 & 0 & 0 & 0 & 0 & 0 & 0 & 0 & 0 & 0 & 0 & 0 \\
\hline Apiuna & Itajaí & 0 & $\overline{0}$ & 0 & 0 & 0 & 0 & 0 & 0 & 0 & 0 & 0 & 0 & 0 & 0 & 0 & 0 & 0 & 0 & 0 & 0 \\
\hline Araquari & Itajaí & 0 & 0 & 0 & 0 & 0 & 0 & 0 & 0 & 0 & 0 & 0 & 0 & 0 & 0 & 0 & 0 & 0 & 0 & 0 & 0 \\
\hline Araranguá & \begin{tabular}{|l|} 
Urussanga \\
\end{tabular} & 0 & 0 & 0 & 0 & 0 & 0 & 0 & 0 & 0 & 0 & 0 & 0 & 0 & 0 & 0 & 0 & 0 & 0 & 0 & 0 \\
\hline Armazém & Urussanga & 0 & 0 & 0 & 0 & 0 & 0 & 0 & 0 & 0 & 0 & 0 & 0 & 0 & 0 & 0 & 0 & 0 & 0 & 0 & 0 \\
\hline Arroio Trinta & Caçador & 0 & 0 & 0 & 0 & 0 & 0 & 0 & 0 & 0 & 0 & 0 & 0 & 0 & 0 & 0 & 0 & 0 & 0 & 0 & 0 \\
\hline Ascurra & \begin{tabular}{|l|} 
Itajai \\
\end{tabular} & 0 & 0 & 0 & 0 & 0 & 0 & 0 & 0 & 0 & 0 & 0 & 0 & 0 & 0 & 0 & 0 & 0 & 0 & 0 & 0 \\
\hline Atalanta & Ituporanga & 0 & 0 & 0 & 0 & 0 & 0 & 0 & 0 & 0 & 0 & 0 & 0 & 0 & 0 & 0 & 0 & 0 & 0 & 0 & 0 \\
\hline
\end{tabular}




\begin{tabular}{|c|c|c|c|c|c|c|c|c|c|c|c|c|c|c|c|c|c|c|c|c|c|}
\hline \multirow{3}{*}{ Atunicipo } & \multirow{3}{*}{ CtA } & \multicolumn{20}{|c|}{ Meses } \\
\hline & & \multicolumn{2}{|c|}{ Out 90} & \multicolumn{2}{|c|}{ Nov 20} & \multicolumn{2}{|c|}{ Dez 90} & \multicolumn{2}{|c|}{ Jan 91} & \multicolumn{2}{|c|}{ Fev 91} & \multicolumn{2}{|c|}{ Nar 91} & \multicolumn{2}{|c|}{ Abt 91} & \multicolumn{2}{|c|}{ Mat 9I } & \multicolumn{2}{|c|}{ Thn 91} & \multicolumn{2}{|c|}{ Jul 91} \\
\hline & & Casos & Fooos & Casos: & foors: & Casos & Foos: & Casos & rooos & Casos: & Focos: & Caros & Focas & Cassos & focos & Casos & Cocas & Casos & Focos & Casus & Focos \\
\hline Aurora & Ituporanga & 0 & 0 & 0 & 0 & 0 & 0 & 0 & 0 & 0 & 0 & 0 & 0 & 0 & 0 & 0 & 0 & 0 & 0 & 0 & 0 \\
\hline Balneário Camboriú & Itajai & 0 & 0 & 0 & 0 & 0 & 0 & 0 & 0 & $\overline{0}$ & 0 & 0 & () & 0 & 0 & 0 & 0 & 0 & 0 & 0 & 0 \\
\hline Barra Velha & Itajaí & 0 & 0 & 0 & 0 & 0 & 0 & 0 & 0 & 0 & 0 & 0 & 0 & 0 & 0 & 0 & 0 & 0 & 0 & 0 & 0 \\
\hline Benedito Novo & Itajaí & 0 & 0 & 0 & 0 & 0 & 0 & 0 & 0 & $\overline{0}$ & 0 & 0 & 0 & 0 & 0 & 0 & 0 & 0 & 0 & 0 & 0 \\
\hline Biguaçu & Florianópolis & 0 & 0 & 0 & 0 & 0 & 0 & 0 & 0 & 0 & 0 & 0 & 0 & 0 & 0 & 0 & 0 & 0 & 0 & 0 & 0 \\
\hline Blumenau & Itajaí & 0 & 0 & 0 & 0 & 0 & 0 & 0 & 0 & 0 & 0 & 0 & 0 & 0 & 0 & 0 & 0 & 0 & 0 & 0 & 0 \\
\hline Bom Jardim da Serra & Lages & 0 & 0 & 5 & 1 & 13 & 2 & 52 & 1 & $\overline{0}$ & 0 & 0 & 0 & 0 & 0 & 0 & 0 & 0 & 0 & 0 & 0 \\
\hline Bom Retiro & Lages & 0 & 0 & 0 & 0 & 2 & 2 & 0 & 0 & 0 & 0 & 0 & 0 & 0 & 0 & 0 & 0 & 0 & 0 & 0 & 0 \\
\hline Botuverá & Itajai & 0 & 0 & 0 & 0 & 0 & 0 & 0 & 0 & 0 & 0 & 0 & 0 & 0 & 0 & 0 & 0 & 0 & 0 & 0 & 0 \\
\hline Braço do Norte & Urussanga & 0 & 0 & 0 & 0 & 0 & 0 & 0 & 0 & 0 & 0 & 0 & 0 & 0 & 0 & 0 & 0 & 0 & 0 & 0 & 0 \\
\hline Brusque & Itajai & 0 & 0 & 0 & 0 & 0 & 0 & 0 & 0 & 0 & 0 & 0 & 0 & 0 & 0 & 0 & 0 & 0 & 0 & 0 & 0 \\
\hline Caçador & Caçador & 0 & 0 & 80 & 1 & 179 & 3 & 55 & 1 & 0 & 0 & 0 & 0 & 0 & 0 & 0 & 0 & 0 & 0 & 0 & 0 \\
\hline Caibi & Chapecó & 0 & 0 & 0 & 0 & 0 & 0 & 0 & 0 & 0 & 0 & 0 & 0 & 0 & 0 & 0 & 0 & 0 & 0 & 0 & 0 \\
\hline Camboriú & Itajaí & 0 & 0 & 0 & 0 & 0 & 0 & 0 & 0 & 0 & 0 & 0 & 0 & 0 & 0 & 0 & 0 & 0 & 0 & 0 & 0 \\
\hline Campo Alegre & Canoinhas & 0 & 0 & 0 & 0 & 0 & 0 & 0 & 0 & 0 & 0 & 0 & 0 & 0 & 0 & 0 & 0 & 0 & 0 & 0 & 0 \\
\hline Campo Belo do Sul & Lages & 0 & 0 & 21 & 1 & 0 & 0 & 0 & 0 & 0 & 0 & 0 & 0 & 0 & 0 & 0 & 0 & 0 & 0 & 0 & 0 \\
\hline Campo Erê & Chapecó & 0 & 0 & 0 & 0 & 0 & 0 & 0 & 0 & 0 & 0 & 0 & 0 & 0 & 0 & 0 & 0 & 0 & 0 & 0 & $\overline{0}$ \\
\hline Campos Novos & Campos Novos & 0 & 0 & 88 & 4 & 67 & 4 & 0 & 0 & 0 & 0 & 0 & 0 & 0 & 0 & 0 & 0 & $\overline{0}$ & 0 & 0 & 0 \\
\hline Canelinha & Florianópolis & 0 & 0 & 0 & 0 & 0 & 0 & 0 & 0 & 0 & 0 & 0 & 0 & 0 & 0 & 0 & 0 & 0 & 0 & 0 & 0 \\
\hline Canoinhas & Canoinhas & 0 & 0 & 0 & 0 & 0 & 0 & 0 & 0 & 0 & 0 & 0 & 0 & 0 & 0 & 37 & 4 & 35 & 3 & 0 & 0 \\
\hline Capinzal & Campos Novos & 0 & 0 & 0 & 0 & 0 & 0 & 0 & 0 & 0 & 0 & 0 & 0 & 0 & 0 & 0 & 0 & 0 & 0 & 0 & 0 \\
\hline Catanduvas & Campos Novos & 0 & 0 & 4 & I & 0 & 0 & 0 & 0 & 0 & 0 & 0 & 0 & 0 & 0 & 0 & 0 & 0 & 0 & 0 & 0 \\
\hline Caxambú do Sul & Chapecó & 0 & 0 & 0 & 0 & 0 & 0 & 3 & 1 & 0 & 0 & 0 & 0 & 0 & 0 & 0 & 0 & 0 & 0 & 0 & 0 \\
\hline
\end{tabular}

$\varpi$ 


\begin{tabular}{|c|c|c|c|c|c|c|c|c|c|c|c|c|c|c|c|c|c|c|c|c|c|}
\hline \multirow{3}{*}{ Municipio } & \multirow{3}{*}{ Cra } & \multicolumn{20}{|c|}{ Meses } \\
\hline & & \multicolumn{2}{|c|}{ Out 90} & \multicolumn{2}{|c|}{$\mathrm{N} / \% 9$} & \multicolumn{2}{|c|}{ Dez 90} & \multicolumn{2}{|c|}{ Jan 91} & \multicolumn{2}{|c|}{ Th+1 91} & \multicolumn{2}{|c|}{ Nar 91} & \multicolumn{2}{|c|}{ (6) 91} & \multicolumn{2}{|c|}{ Mat 91} & \multicolumn{2}{|c|}{ Hort } & \multicolumn{2}{|c|}{$\mathrm{JOO}$} \\
\hline & & Casos & Foors & Casos & Foros & Casos: & Fooss & Casos: & 60005 & Cacos & rooks & Caros & Focos & Casos: & 10008 & Cosos & Focos & Castro & focos & Casos: & Foros \\
\hline Celso Ramos & Lages & 0 & 0 & 0 & 0 & 0 & 0 & 0 & 0 & 0 & 0 & 0 & 0 & 0 & 0 & 0 & 0 & 0 & 0 & 0 & 0 \\
\hline Chapecó & Chapecó & 0 & 0 & 0 & 0 & 0 & 0 & 0 & 0 & 0 & 0 & 0 & 0 & 0 & 0 & 0 & 0 & 0 & 0 & 0 & 0 \\
\hline Concórdia & Concórdia & 0 & 0 & 40 & 7 & 3 & 3 & 0 & 0 & 0 & 0 & 0 & 0 & 0 & 0 & 30 & 1 & 0 & 0 & 0 & 0 \\
\hline Coronel Freitas & Chapecó & 0 & 0 & 0 & 0 & 0 & 0 & 0 & 0 & 0 & 0 & 0 & 0 & 10 & 1 & 226 & 10 & 0 & 0 & 0 & 0 \\
\hline Correia Pinto & Lages & 0 & 0 & 484 & 2 & 7 & 1 & 0 & 0 & 0 & 0 & 0 & 0 & 0 & 0 & 0 & 0 & 0 & 0 & 0 & 0 \\
\hline Corupa & Itajaí & 0 & 0 & 0 & 0 & 0 & 0 & 0 & 0 & 0 & 0 & 0 & 0 & 0 & 0 & 0 & 0 & 0 & 0 & 0 & 0 \\
\hline Corupá & Itajaí & 0 & 0 & 0 & 0 & 0 & 0 & 0 & 0 & 0 & 0 & 0 & 0 & 0 & 0 & 0 & 0 & 0 & 0 & 0 & 0 \\
\hline Criciúma & Urussanga & 0 & 0 & 0 & 0 & 0 & 0 & 0 & 0 & 0 & 0 & 0 & 0 & 0 & 0 & 0 & 0 & 0 & 0 & 0 & 0 \\
\hline Cunha Porã & Chapecó & 0 & 0 & 0 & 0 & 0 & 0 & 0 & 0 & 0 & 0 & 0 & 0 & 0 & 0 & 0 & 0 & 0 & 0 & 0 & 0 \\
\hline Curitibanos & Caçador & 0 & 0 & 0 & 0 & 0 & 0 & 0 & 0 & 0 & 0 & 0 & 0 & 0 & 0 & 0 & 0 & 0 & 0 & 0 & 0 \\
\hline Descanso & Chapecó & 0 & 0 & 0 & 0 & 0 & 0 & 0 & 0 & 0 & 0 & 0 & 0 & 0 & 0 & 35 & 4 & 36 & 3 & 0 & 0 \\
\hline Dionísio Cerqueira & Chapecó & 0 & 0 & 0 & 0 & 0 & 0 & 0 & 0 & 0 & 0 & 0 & 0 & 0 & 0 & 0 & 0 & 0 & 0 & 0 & 0 \\
\hline Dona Emma & Ituporanga & 0 & 0 & 0 & 0 & 0 & 0 & 0 & 0 & 0 & 0 & 0 & 0 & 0 & 0 & 0 & 0 & 0 & 0 & 0 & 0 \\
\hline Dr. Pedrinho & Itajaí & 0 & 0 & 0 & 0 & 0 & 0 & 0 & 0 & 0 & 0 & 0 & 0 & 0 & 0 & 0 & 0 & 0 & 0 & 0 & 0 \\
\hline Erval Velho & Campos Novos & 0 & 0 & 0 & 0 & 0 & 0 & 0 & 0 & 0 & 0 & 0 & 0 & 0 & 0 & 0 & 0 & 0 & 0 & 0 & 0 \\
\hline Faxinal Guedes & Concórdia & 0 & 0 & 0 & 0 & 0 & 0 & 0 & 0 & 0 & 0 & 0 & 0 & 0 & 0 & 0 & 0 & 0 & 0 & 0 & 0 \\
\hline Florianópolis & Florianópolis & 0 & 0 & 0 & 0 & 0 & 0 & 0 & 0 & 0 & 0 & 0 & 0 & 0 & 0 & 0 & 0 & 0 & 0 & 0 & 0 \\
\hline Forquilhinha & Urussanga & 0 & 0 & 0 & 0 & 0 & 0 & 0 & 0 & 0 & 0 & 0 & 0 & 0 & 0 & 0 & 0 & 0 & 0 & 0 & 0 \\
\hline Fraiburgo & Caçador & 0 & 0 & 0 & 0 & 0 & 0 & 22 & 1 & 0 & 0 & 0 & 0 & 0 & 0 & 0 & 0 & 0 & 0 & 0 & 0 \\
\hline Galvão & Concórdia & 0 & 0 & 0 & 0 & 0 & 0 & 0 & 0 & 0 & 0 & 0 & 0 & 0 & 0 & 0 & 0 & 0 & 0 & 0 & 0 \\
\hline Garopaba & Florianópolis & 0 & 0 & 0 & 0 & 0 & 0 & 0 & 0 & 0 & 0 & 0 & 0 & 0 & 0 & 0 & 0 & 0 & 0 & 0 & 0 \\
\hline Garuva & Itajaí & 0 & 0 & 0 & 0 & 0 & 0 & 0 & 0 & 0 & 0 & 0 & 0 & 0 & 0 & 0 & 0 & 0 & 0 & 0 & 0 \\
\hline Gov. Celso Ramos & Florianópolis & 0 & 0 & 0 & 0 & 0 & 0 & 0 & 0 & 0 & 0 & 0 & 0 & 0 & 0 & 0 & 0 & 0 & 0 & 0 & 0 \\
\hline
\end{tabular}

$\infty$ 


\begin{tabular}{|c|c|c|c|c|c|c|c|c|c|c|c|c|c|c|c|c|c|c|c|c|c|}
\hline \multirow{3}{*}{ Uunicipio } & \multirow{3}{*}{ CTA } & \multicolumn{20}{|c|}{ Meses } \\
\hline & & \multicolumn{2}{|c|}{ Out 90} & \multicolumn{2}{|c|}{ NoY 90} & \multicolumn{2}{|c|}{ Det 90} & \multicolumn{2}{|c|}{ tan 91} & \multicolumn{2}{|c|}{ Tet 91} & \multicolumn{2}{|c|}{ Mol 91} & \multicolumn{2}{|c|}{ Ab/ 91} & \multicolumn{2}{|c|}{ Mar 91} & \multicolumn{2}{|c|}{ Jon 91} & \multicolumn{2}{|c|}{ Jut. 91} \\
\hline & & Casos & Fooos & Casos & fororos: & Casos & Fooos: & Cusos & foroos: & Caros: & foons & Casos: & focas & Casos: & focos & Casas & focos & Casus & fooos & Cosus & Focos \\
\hline Grão Pará & Urussanga & 0 & 0 & 0 & 0 & 0 & 0 & 0 & 0 & 0 & 0 & 0 & 0 & 0 & 0 & 0 & 0 & 0 & 0 & 0 & 0 \\
\hline Gravatal & Urussanga & 0 & 0 & 0 & 0 & 0 & () & 38 & 1 & 265 & 1 & 23 & 1 & 0 & 0 & 0 & 0 & 0 & 0 & 0) & 0 \\
\hline Guabiruba & Itajaí & 0 & 0 & 0 & 0 & 0 & 0 & 0 & 0 & 0 & 0 & 0 & 0 & 0 & 0 & 0 & 0 & 0 & 0 & 0 & 0 \\
\hline Guaraciaba & Chapecó & 0 & 0 & 0 & 0 & 0 & 0 & 0 & 0 & 0 & 0 & 0 & 0 & 0 & 0 & 0 & 0 & 2 & 1 & 0 & 0 \\
\hline Guaramirim & Itajaí & 0 & 0 & 0 & 0 & 0 & 0 & 0 & 0 & 0 & 0 & 0 & 0 & 0 & 0 & 0 & 0 & 0 & 0 & 0 & 0 \\
\hline Guarujá do Sul & Chapecó & 0 & 0 & 0 & 0 & 0 & 0 & 0 & 0 & 0 & 0 & 0 & 0 & 0 & 0 & 0 & 0 & 0 & 0 & 0 & 0 \\
\hline Herval D'Oeste & Campos Novos & 0 & 0 & 0 & 0 & 0 & 0 & 0 & 0 & 0 & 0 & 0 & 0 & 0 & 0 & 0 & 0 & 0 & 0 & 0 & 0 \\
\hline Ibicaré & Campos Novos & 0 & 0 & 0 & 0 & 0 & 0 & 0 & 0 & 0 & 0 & 0 & 0 & 0 & 0 & 0 & 0 & 0 & 0 & $\overline{0}$ & 0 \\
\hline Ibirama & Ituporanga & 0 & 0 & 0 & 0 & 0 & 0 & 0 & 0 & 0 & 0 & 0 & 0 & 0 & 0 & 0 & 0 & 0 & 0 & 0 & 0 \\
\hline Içara & Urussanga & 0 & 0 & 0 & 0 & 0 & 0 & 0 & 0 & 0 & 0 & 0 & 0 & 0 & 0 & 0 & 0 & 0 & 0 & 0 & 0 \\
\hline Ilhota & Itajaí & 0 & 0 & 0 & 0 & 0 & 0 & 0 & 0 & 0 & 0 & 0 & 0 & 0 & 0 & 0 & 0 & 0 & 0 & 0 & 0 \\
\hline Imaruí & Urussanga & 0 & 0 & 0 & 0 & 0 & 0 & 0 & 0 & 0 & 0 & 0 & 0 & 0 & 0 & 0 & 0 & 0 & 0 & 0 & 0 \\
\hline Imbituba & Urussanga & 0 & 0 & 0 & 0 & 0 & 0 & 0 & 0 & 0 & 0 & 0 & 0 & 0 & 0 & 0 & 0 & 0 & 0 & 0 & 0 \\
\hline Imbuia & Ituporanga & 0 & 0 & 0 & 0 & 0 & 0 & 0 & 0 & 0 & 0 & 0 & 0 & 0 & 0 & 0 & 0 & 0 & 0 & 0 & 0 \\
\hline Indaial & Itajaí & 0 & 0 & 0 & 0 & 0 & 0 & 0 & 0 & 0 & 0 & 0 & 0 & 0 & 0 & 0 & 0 & 0 & 0 & 0 & 0 \\
\hline Ipira & Concórdia & 0 & 0 & 0 & 0 & 0 & 0 & 0 & 0 & 0 & 0 & 0 & 0 & 0 & 0 & 0 & 0 & 0 & 0 & 0 & 0 \\
\hline Iporã D'Oeste & Chapecó & 0 & 0 & 0 & 0 & 0 & 0 & 0 & 0 & 0 & 0 & 0 & 0 & 0 & 0 & 0 & 0 & 0 & 0 & 0 & 0 \\
\hline Ipumirim & Concórdia & 0 & 0 & 0 & 0 & 0 & 0 & 0 & 0 & 0 & 0 & 0 & 0 & 0 & 0 & 0 & 0 & 0 & 0 & 0 & 0 \\
\hline Iraceminha & Chapecó & 0 & 0 & 0 & 0 & 0 & 0 & 0 & 0 & 0 & 0 & 0 & 0 & 0 & 0 & 0 & 0 & 0 & 0 & 0 & 0 \\
\hline Irani & Concórdia & 0 & 0 & 0 & 0 & 0 & 0 & 0 & 0 & 0 & 0 & 0 & 0 & 0 & 0 & 0 & 0 & 0 & 0 & 0 & 0 \\
\hline Irineópolis & Canoinhas & 0 & 0 & 0 & 0 & 0 & 0 & 0 & 0 & 0 & 0 & 0 & 0 & 0 & 0 & 0 & 0 & 0 & 0 & 0 & 0 \\
\hline Itá & Concórdia & 0 & 0 & 0 & 0 & 0 & 0 & 0 & 0 & 0 & 0 & 0 & 0 & 0 & 0 & 0 & 0 & 0 & 0 & 0 & 0 \\
\hline Itaiópolis & Canoinhas & 0 & 0 & 0 & 0 & 0 & 0 & 0 & 0 & 0 & 0 & 0 & 0 & 0 & 0 & 0 & 0 & 0 & 0 & 0 & 0 \\
\hline
\end{tabular}




\begin{tabular}{|c|c|c|c|c|c|c|c|c|c|c|c|c|c|c|c|c|c|c|c|c|c|}
\hline \multirow{3}{*}{ Aunicipio } & \multirow{3}{*}{ CtA } & \multicolumn{20}{|c|}{ Meses } \\
\hline & & \multicolumn{2}{|c|}{ Out. 90} & \multicolumn{2}{|c|}{ Nov 99} & \multicolumn{2}{|c|}{ Det 90} & \multicolumn{2}{|c|}{$\tan 91$} & \multicolumn{2}{|c|}{ Eet 91} & \multicolumn{2}{|c|}{ Nat.91 } & \multicolumn{2}{|c|}{ Abt 91} & \multicolumn{2}{|c|}{ Mat 91} & \multicolumn{2}{|c|}{ Jun 91} & \multicolumn{2}{|c|}{ Jul 91} \\
\hline & & Casos & Pocos & Casos & Fooss & Casot & Fooos & Casos & Focos & Casos & Focos & Castos & Focas & Casos & Focas & Casos & Focos & Casoss & Focos & Casos & Focos \\
\hline Itajaí & Itajai & () & 0 & 0 & 0) & 0 & 0 & 0 & 0) & 0 & () & 0 & () & 0 & 0 & 0 & 0 & 0 & 0 & 0 & 0 \\
\hline Itapema & Itajai & 0 & 0 & 0 & 0) & 0 & 0) & 0) & 0 & 0 & 0 & 0 & 0 & 0 & 0 & 0 & 0 & 0 & 0 & () & 0 \\
\hline Itapiranga & Chapecó & () & 0 & 0 & 0 & 0 & 0 & 0 & 0 & 0 & 0 & 0 & 0 & 0 & 0 & () & () & 0 & 0 & 0 & 0 \\
\hline Itapoã & Itajaí & 0 & 0 & 0 & 0 & 0 & 0 & 0 & 0 & 0 & 0 & 0 & 0 & 0 & 0 & 0 & 0 & 0 & 0 & 0 & 0 \\
\hline Ituporanga & Ituporanga & 0 & 0 & 0 & 0 & 0 & 0 & 0 & 0 & 0 & 0 & 0 & 0 & 0 & 0 & 0 & 0 & 0 & 0 & 0 & 0 \\
\hline Jaborá & Concórdia & 0 & 0 & 0 & 0 & 0 & 0 & 0 & 0 & 0 & 0 & 0 & 0 & 0 & 0 & 0 & 0 & 0 & 0 & 0 & 0 \\
\hline Jacinto Machado & Urussanga & 0 & 0 & 0 & 0 & 0 & 0 & 0 & 0 & 0 & 0 & 0 & 0 & 4 & 1 & 0 & 0 & 0 & 0 & 0 & 0 \\
\hline Jaguaruna & Urussanga & 0 & 0 & 0 & 0 & 0 & 0 & 0 & 0 & 0 & 0 & 0 & 0 & 0 & 0 & 0 & 0 & 0 & 0 & 0 & 0 \\
\hline Jaraguá do Sul & Itajai & 0 & 0 & 0 & 0 & 0 & 0 & 0 & 0 & 0 & 0 & 0 & 0 & 0 & 0 & 0 & 0 & 0 & 0 & 0 & 0 \\
\hline Joaçaba & Campos Novos & 0 & 0 & 39 & 3 & 45 & 1 & 0 & 0 & 0 & 0 & 0 & 0 & 0 & 0 & 0 & 0 & 0 & 0 & 0 & 0 \\
\hline Joinville & Itajai & 0 & 0 & 0 & 0 & 0 & 0 & 0 & 0 & 0 & 0 & 0 & 0 & 0 & 0 & 0 & 0 & 0 & 0 & 0 & 0 \\
\hline José Boiteux & Ituporanga & 0 & 0 & 0 & 0 & 0 & 0 & 0 & 0 & 0 & 0 & 0 & 0 & 0 & 0 & 0 & 0 & 0 & 0 & 0 & 0 \\
\hline Lacerdópolis & Campos Novos & 0 & 0 & 18 & 2 & 0 & 0 & 0 & () & 0 & 0 & 0 & 0 & 0 & 0 & 0 & 0 & 0 & 0 & 0 & 0 \\
\hline Lages & Lages & 0 & 0 & 924 & 12 & 150 & 7 & 0 & () & 0 & 0 & 0 & 0 & 0 & 0 & 0 & 0 & 0 & 0 & 0 & 0 \\
\hline Laguna & Urussanga & 0 & 0 & 0 & 0 & 0 & 0 & 0 & 0 & 0 & 0 & 177 & 1 & 0 & 0 & 0 & 0 & 0 & 0 & 0 & 0 \\
\hline Laurentino & Ituporanga & 0 & 0 & 0 & 0 & 0 & 0 & 0 & 0 & 0 & 0 & 0 & 0 & 0 & 0 & 0 & 0 & 0 & 0 & 0 & 0 \\
\hline Lauro Muller & Urussanga & 0 & 0 & 0 & 0 & 0 & 0 & 0 & 0 & 0 & 0 & 0 & 0 & 0 & 0 & 0 & 0 & 0 & 0 & 0 & 0 \\
\hline Lebon Régis & Caçador & 0 & 0 & 120 & 2 & 0 & 0 & 0 & 0 & 0 & 0 & 0 & 0 & 0 & 0 & 0 & 0 & 0 & 0 & 0 & 0 \\
\hline Leoberto Leal & Ituporanga & 0 & 0 & 0 & 0 & 0 & 0 & 0 & 0 & 0 & 0 & 0 & 0 & 0 & 0 & 0 & 0 & 0 & 0 & 0 & 0 \\
\hline Lindóia do Sul & Concórdia & 0 & 0 & 0 & 0 & 0 & 0 & 0 & 0 & 0 & 0 & 0 & 0 & 0 & 0 & 0 & 0 & 0 & 0 & 0 & 0 \\
\hline Lontras & Ituporanga & 0 & 0 & 0 & 0 & 0 & 0 & 0 & 0 & 0 & 0 & 0 & 0 & 0 & 0 & 0 & 0 & 0 & 0 & 0 & 0 \\
\hline Luiz Alves & Itajai & 0 & 0 & 0 & 0 & 0 & 0 & 0 & 0 & 0 & 0 & 0 & 0 & 0 & 0 & 0 & 0 & 0 & 0 & 0 & 0 \\
\hline Mafra & Canoinhas & 0 & 0 & 0 & 0 & 106 & 3 & 0 & 0 & 0 & 0 & 0 & 0 & 0 & 0 & 0 & 0 & 0 & 0 & 0 & 0 \\
\hline
\end{tabular}




\begin{tabular}{|c|c|c|c|c|c|c|c|c|c|c|c|c|c|c|c|c|c|c|c|c|c|}
\hline \multirow{3}{*}{ Municipio } & \multirow{3}{*}{ CTA } & \multicolumn{20}{|c|}{ Meses } \\
\hline & & \multicolumn{2}{|c|}{ out 90} & \multicolumn{2}{|c|}{ Nov 90} & \multicolumn{2}{|c|}{ Dez 90} & \multicolumn{2}{|c|}{$\operatorname{Jan} 91$} & \multicolumn{2}{|c|}{ rov 91} & \multicolumn{2}{|c|}{ Aar 91} & \multicolumn{2}{|c|}{$\mathrm{Abr}, 91$} & \multicolumn{2}{|c|}{ Mai 91} & \multicolumn{2}{|c|}{$\operatorname{tun} 91$} & \multicolumn{2}{|c|}{ Jul 91} \\
\hline & & Casos & Focos & Casos & Focos & Casas & focos & Casos & focos & Casos & Foros & Casos & Focos & Casos & Focos & Cassos & Focos & Casos & Foros & Casoss & Foras \\
\hline Major Gercino & Florianopolis & 0 & 0 & 0 & 0 & 0 & 0 & 0 & 0 & 0 & 0 & 0 & 0 & 0 & 0 & 0 & 0 & 0 & 0 & 0 & 0 \\
\hline Major Vieira & Canoinhas & 0 & 0 & 0 & 0 & 0 & 0 & 0 & 0 & 0 & 0 & 0 & 0 & 0 & 0 & 0 & 0 & 0 & 0 & 0 & 0 \\
\hline Maracaja & Urussanga & 0 & 0 & 0 & 0 & 0 & 0 & 0 & 0 & $\overline{0}$ & 0 & 0 & 0 & 0 & 0 & 0 & 0 & 0 & 0 & 0 & 0 \\
\hline Maravilha & Chapecó & 0 & 0 & 0 & 0 & 0 & 0 & 0 & 0 & 0 & 0 & 0 & 0 & 0 & 0 & 0 & 0 & 0 & 0 & 0 & 0 \\
\hline Marema & Concórdia & 0 & 0 & 0 & 0 & 0 & 0 & 0 & 0 & 0 & 0 & 0 & 0 & 117 & 20 & 19 & 6 & 0 & 0 & 0 & 0 \\
\hline Massaranduba & Itajai & 0 & 0 & 0 & 0 & 0 & 0 & 0 & 0 & 0 & 0 & 0 & 0 & 0 & 0 & 0 & 0 & 0 & 0 & 0 & 0 \\
\hline Matos Costas & Caçador & 18 & 1 & 286 & 3 & 92 & 5 & 0 & 0 & 0 & 0 & 0 & 0 & 0 & 0 & 0 & 0 & 0 & 0 & 0 & 0 \\
\hline Meleiro & Urussanga & 0 & 0 & 0 & 0 & 0 & 0 & 0 & 0 & 0 & 0 & 0 & 0 & 0 & 0 & 0 & 0 & 0 & 0 & 0 & 0 \\
\hline Modelo & Chapecó & 0 & 0 & 0 & 0 & 0 & 0 & 0 & 0 & 0 & 0 & 0 & 0 & 0 & 0 & 0 & 0 & 0 & 0 & 0 & 0 \\
\hline Mondai & Chapecó & 0 & 0 & 0 & 0 & 0 & 0 & 0 & 0 & 0 & 0 & 0 & 0 & 0 & 0 & 0 & 0 & 0 & 0 & 0 & 0 \\
\hline Monte Carlo & Campos Novos & 0 & 0 & 0 & 0 & 0 & 0 & 0 & 0 & 0 & 0 & 0 & 0 & 0 & 0 & 0 & 0 & 0 & 0 & 0 & 0 \\
\hline Monte Castelo & Canoinhas & 0 & 0 & 0 & 0 & 0 & 0 & 0 & 0 & 0 & 0 & 0 & 0 & 0 & 0 & 0 & 0 & 0 & 0 & 0 & $\overline{0}$ \\
\hline Morro da Fumaça & Urussanga & 0 & 0 & 0 & 0 & 0 & 0 & 0 & 0 & 0 & 0 & 0 & 0 & 0 & 0 & 0 & 0 & 0 & 0 & 0 & 0 \\
\hline Navegantes & Itajai & 0 & 0 & 0 & 0 & 0 & 0 & 0 & 0 & 0 & 0 & 0 & 0 & 0 & 0 & $\begin{array}{ll}0 \\
0\end{array}$ & 0 & 0 & 0 & 0 & 0 \\
\hline Nova Erechim & Chapecó & 0 & 0 & 0 & 0 & $\overline{0}$ & 0 & 0 & 0 & 0 & 0 & 0 & 0 & 0 & 0 & 0 & 0 & 0 & 0 & 0 & 0 \\
\hline Nova Trento & Florianópolis & 0 & 0 & 0 & 0 & 0 & 0 & 0 & 0 & 0 & 0 & 0 & 0 & 0 & 0 & 0 & 0 & 0 & 0 & 0 & 0 \\
\hline Nova Veneza & Urussanga & 0 & 0 & 0 & 0 & 0 & 0 & 0 & 0 & 0 & 0 & 0 & 0 & 0 & 0 & 0 & 0 & 0 & 0 & 0 & 0 \\
\hline Orleans & Urussanga & 0 & 0 & 0 & 0 & 0 & 0 & 0 & 0 & 0 & 0 & 0 & 0 & 0 & 0 & 0 & 0 & 0 & 0 & 0 & 0 \\
\hline Otacilio Costa & Lages & 0 & 0 & 77 & 2 & 0 & 0 & 0 & 0 & 0 & 0 & 0 & 0 & 0 & 0 & 0 & 0 & 0 & 0 & 0 & 0 \\
\hline Ouro & Campos Novos & 0 & 0 & 1 & 2 & 5 & 1 & 0 & 0 & 0 & 0 & 0 & 0 & 0 & 0 & 0 & 0 & 0 & 0 & 0 & 0 \\
\hline Palhoça & Florianópolis & 0 & 0 & 0 & 0 & 0 & 0 & 0 & 0 & 0 & 0 & 0 & 0 & 0 & 0 & 0 & 0 & 0 & 0 & 0 & 0 \\
\hline Palma Sola & Chapecó & 0 & 0 & 0 & 0 & 0 & 0 & 0 & 0 & 0 & 0 & 0 & 0 & 0 & 0 & 0 & 0 & 0 & 0 & 0 & 0 \\
\hline Palmitos & Chapecó & 0 & 0 & 0 & 0 & 0 & 0 & 0 & 0 & 0 & 0 & 0 & 0 & 0 & 0 & 0 & 0 & 0 & 0 & 0 & 0 \\
\hline
\end{tabular}




\begin{tabular}{|c|c|c|c|c|c|c|c|c|c|c|c|c|c|c|c|c|c|c|c|c|c|}
\hline \multirow[t]{2}{*}{ Mnícipo } & \multirow[t]{2}{*}{$\mathrm{CH}$} & \multicolumn{2}{|c|}{ out 90} & \multicolumn{2}{|c|}{ Nov, 90} & \multicolumn{2}{|c|}{ Det 90} & \multicolumn{2}{|c|}{ Tan 91} & \multicolumn{2}{|c|}{ Fou. 91} & \multicolumn{2}{|c|}{ Nat 91} & \multicolumn{2}{|c|}{ Ator 91} & \multicolumn{2}{|c|}{ Mai 91} & \multicolumn{2}{|c|}{ Tun 91} & \multicolumn{2}{|c|}{ Jul 91} \\
\hline & & Casos & Foos & Casos & Foors & Casos: & Fooos & Casos & Focos & Casos & Focos & Casos & Focos & Casos & Tocos & Cosos & Focos: & Casos & Tocos: & Casos & Focos \\
\hline Papanduva & Canoinhas & 0 & 0 & 0 & 0 & 0 & 0 & 0 & 0 & 0 & 0 & 0 & 0 & 0 & 0 & 0 & 0 & 0 & 0 & 0 & 0 \\
\hline Paulo Lopes & Florianópolis & 0 & 0 & 0 & 0 & 0 & 0 & 0 & 0 & 0 & 0 & 0 & 0 & 0 & 0 & 0 & 0 & 0 & 0 & 0 & 0 \\
\hline Pedras Grandes & Urussanga & 0 & 0 & 0 & 0 & 0 & 0 & 0 & 0 & 0 & 0 & 0 & 0 & 0 & 0 & 0 & 0 & 0 & 0 & 0 & 0 \\
\hline Penha & Itajai & 0 & 0 & 0 & 0 & 0 & 0 & 0 & 0 & 0 & 0 & 0 & 0 & 0 & 0 & 0 & 0 & 0 & 0 & 0 & 0 \\
\hline Peritiba & Concórdia & 0 & 0 & 0 & 0 & 0 & 0 & 0 & 0 & 0 & 0 & 0 & 0 & 0 & 0 & 0 & 0 & 0 & 0 & 0 & 0 \\
\hline Petrolândia & Ituporanga & 0 & 0 & 0 & 0 & 0 & 0 & 0 & 0 & 0 & 0 & 0 & 0 & 0 & 0 & 0 & 0 & 0 & 0 & 0 & 0 \\
\hline Piçarras & \begin{tabular}{|l|} 
Itajaí \\
\end{tabular} & 0 & 0 & 0 & 0 & 0 & 0 & 0 & 0 & 0 & 0 & 0 & 0 & 0 & 0 & 0 & 0 & 0 & 0 & 0 & 0 \\
\hline Pinhalzinho & Chapecó & 0 & 0 & 0 & 0 & 0 & 0 & 0 & 0 & 0 & 0 & 0 & 0 & 0 & 0 & 0 & 0 & 0 & 0 & 0 & 0 \\
\hline Pinheiro Preto & Campos Novos & 0 & 0 & 0 & 0 & 0 & 0 & 0 & 0 & 0 & 0 & 0 & 0 & 0 & 0 & 0 & 0 & 0 & 0 & 0 & 0 \\
\hline Piratuba & Concórdia & 0 & 0 & 0 & 0 & 0 & 0 & 0 & 0 & 0 & 0 & 0 & 0 & 0 & 0 & 0 & 0 & 0 & 0 & 0 & 0 \\
\hline Pomerode & Itajai & 0 & 0 & 0 & 0 & 0 & 0 & 0 & 0 & 0 & 0 & 0 & 0 & 0 & 0 & 0 & 0 & 0 & 0 & 0 & 0 \\
\hline Ponte Alta & Lages & 0 & 0 & 0 & 0 & 0 & 0 & 0 & 0 & 0 & 0 & 0 & 0 & 0 & 0 & 0 & 0 & 0 & 0 & 0 & 0 \\
\hline Ponte Serrada & Concórdia & 0 & 0 & 0 & 0 & 0 & 0 & 0 & 0 & 0 & 0 & 0 & 0 & 0 & 0 & 0 & 0 & 0 & 0 & 0 & 0 \\
\hline Porto Belo & Itajai & 0 & 0 & 0 & 0 & 0 & 0 & 0 & 0 & 0 & 0 & 0 & 0 & 0 & 0 & 0 & 0 & 0 & 0 & 0 & 0 \\
\hline Porto União & Canoinhas & 0 & 0 & 0 & 0 & 0 & 0 & 0 & 0 & 0 & 0 & 0 & 0 & 0 & 0 & 0 & 0 & 0 & 0 & 0 & 0 \\
\hline Pouso Redondo & Ituporanga & 0 & 0 & 0 & 0 & 0 & 0 & 0 & 0 & 0 & 0 & 0 & 0 & 0 & 0 & 0 & 0 & 0 & 0 & 0 & 0 \\
\hline Praia Grande & Urussanga & 0 & 0 & 0 & 0 & 0 & 0 & 0 & 0 & 0 & 0 & 0 & 0 & 0 & 0 & 0 & 0 & 0 & 0 & 0 & 0 \\
\hline Pres. Castelo Branco & Concórdia & 0 & 0 & 0 & 0 & 0 & 0 & 0 & 0 & 0 & 0 & 0 & 0 & 0 & 0 & 0 & 0 & 0 & 0 & 0 & 0 \\
\hline Presidente Getúlio & Ituporanga & 0 & 0 & 0 & 0 & 0 & 0 & 0 & 0 & 0 & 0 & 0 & 0 & 0 & 0 & 0 & 0 & 0 & 0 & $\overline{0}$ & 0 \\
\hline Presidente Nereu & Ituporanga & 0 & 0 & 0 & 0 & 0 & 0 & 0 & 0 & 0 & 0 & 0 & 0 & 0 & 0 & 0 & 0 & 0 & 0 & 0 & 0 \\
\hline Quilombo & Chapecó & 0 & 0 & 0 & 0 & 0 & 0 & 0 & 0 & 0 & 0 & 9 & 1 & 140 & 12 & 6 & 2 & 0 & 0 & 0 & 0 \\
\hline Rancho Queimado & Florianópolis & 0 & 0 & 0 & 0 & 93 & 3 & 65 & 3 & 0 & 0 & 0 & 0 & 0 & 0 & 0 & 0 & 0 & 0 & 0 & 0 \\
\hline Rio Campo & Ituporanga & 0 & 0 & 0 & 0 & 0 & 0 & 0 & 0 & 0 & 0 & 0 & 0 & 0 & 0 & 0 & 0 & 0 & 0 & 0 & 0 \\
\hline
\end{tabular}

$\infty$ 


\begin{tabular}{|c|c|c|c|c|c|c|c|c|c|c|c|c|c|c|c|c|c|c|c|c|c|}
\hline \multirow{3}{*}{ Municipio } & \multirow{3}{*}{ CTA } & \multicolumn{20}{|c|}{ Meses } \\
\hline & & \multicolumn{2}{|c|}{ out 90} & \multicolumn{2}{|c|}{ Nov 90} & \multicolumn{2}{|c|}{ Dex 90} & \multicolumn{2}{|c|}{ 3an 91} & \multicolumn{2}{|c|}{ F०थ 91} & \multicolumn{2}{|c|}{ Mat 91} & \multicolumn{2}{|c|}{ Alorot } & \multicolumn{2}{|c|}{ Mai 91} & \multicolumn{2}{|c|}{$\operatorname{tin} 91$} & \multicolumn{2}{|c|}{ Jul 91} \\
\hline & & Casos & Foos & Casus & Focos & Casos: & focos & Casos & Focos & Casos & Focos & Casos: & Focos & Casos & focos & Casos & Focos & Casions & Foods & Casos & Focos \\
\hline Rio das Antas & Caçador & 0 & 0 & 0 & 0 & 0 & 0 & 0 & 0 & 0 & 0 & 0 & 0 & 0 & 0 & 0 & 0 & 0 & 0 & 0 & 0 \\
\hline Rio do Oeste & Ituporanga & 0 & 0 & 0 & 0 & 0 & 0 & 0 & 0 & 0 & 0 & 13 & 1 & 0 & 0 & 0 & 0 & 0 & 0 & 0 & 0 \\
\hline Rio do Sul & Ituporanga & 0 & 0 & 0 & 0 & 0 & 0 & 0 & 0 & 0 & 0 & 0 & 0 & 0 & 0 & 0 & 0 & 0 & 0 & 0 & 0 \\
\hline Rio dos Cedros & Itajai & 0 & 0 & 0 & 0 & 0 & 0 & 0 & 0 & 0 & 0 & 0 & 0 & 0 & 0 & 0 & 0 & 0 & 0 & 0 & 0 \\
\hline Rio Fortuna & Urussanga & 0 & 0 & 0 & 0 & 0 & 0 & 0 & 0 & 0 & 0 & 0 & 0 & 0 & 0 & 0 & 0 & 0 & 0 & 0 & 0 \\
\hline Rio Negrinho & Canoinhas & 0 & 0 & 0 & 0 & 0 & 0 & 5 & 2 & 0 & 0 & 0 & 0 & 0 & 0 & 0 & 0 & 0 & 0 & 0 & 0 \\
\hline Riqueza D'Oeste & Chapecó & 0 & 0 & 0 & 0 & 0 & 0 & 0 & 0 & 0 & 0 & 0 & 0 & 0 & 0 & 0 & 0 & 0 & 0 & 0 & 0 \\
\hline Rodeio & Itajai & 0 & 0 & 0 & 0 & 0 & 0 & 0 & 0 & 0 & 0 & 0 & 0 & 0 & 0 & 0 & 0 & 0 & 0 & 0 & 0 \\
\hline Romelândia & Chapecó & 0 & 0 & 0 & 0 & 0 & 0 & 0 & 0 & 0 & 0 & 0 & 0 & 0 & 0 & 0 & 0 & 0 & 0 & 0 & 0 \\
\hline S. Amaro da Imperatriz & Florianópolis & 0 & 0 & 0 & 0 & 2 & 1 & 0 & 0 & 0 & 0 & 0 & 0 & 0 & 0 & 0 & 0 & 0 & 0 & 0 & 0 \\
\hline S. José do Cerrito & Lages & 0 & 0 & 0 & 0 & 22 & 1 & 0 & 0 & 0 & 0 & 0 & 0 & 0 & 0 & 0 & 0 & 0 & 0 & 0 & 0 \\
\hline S. José dos Cedros & Chapecó & 0 & 0 & 8 & 2 & 2 & 1 & 0 & 0 & 0 & 0 & 0 & 0 & 0 & 0 & 5 & 1 & 0 & 0 & 0 & 0 \\
\hline S. Lourenço D'Oeste & Chapecó & 0 & 0 & 0 & 0 & 62 & 8 & 0 & 0 & 0 & 0 & 0 & 0 & 0 & 0 & 0 & 0 & 0 & 0 & 0 & 0 \\
\hline S. Miguel D'Oeste & Chapecó & 0 & 0 & 0 & 0 & 0 & 0 & 0 & 0 & 0 & 0 & 0 & 0 & 0 & 0 & 388 & 64 & 35 & 15 & 0 & 0 \\
\hline Salete & Ituporanga & 0 & 0 & 0 & 0 & 0 & 0 & 0 & 0 & 0 & 0 & 0 & 0 & 0 & 0 & 0 & 0 & 0 & 0 & 0 & 0 \\
\hline Salto Veloso & Caçador & 0 & 0 & 0 & 0 & 0 & 0 & 0 & 0 & 0 & 0 & 0 & 0 & 0 & 0 & 0 & 0 & 0 & 0 & 0 & 0 \\
\hline Santa Cecilia & Caçador & 163 & 1 & 0 & 0 & 0 & 0 & 0 & 0 & 0 & 0 & 0 & 0 & 0 & 0 & 0 & 0 & 0 & 0 & 0 & 0 \\
\hline Santa Rosa de Lima & Urussanga & 0 & 0 & 0 & 0 & 0 & 0 & 0 & 0 & 0 & 0 & 0 & 0 & 0 & 0 & 0 & 0 & 0 & 0 & 0 & 0 \\
\hline Santa Rosa do Sul & Urussanga & 0 & 0 & 0 & 0 & 0 & 0 & 0 & 0 & 0 & 0 & 0 & 0 & 22 & 4 & 0 & 0 & 0 & 0 & 0 & 0 \\
\hline São Bento do Sul & Canoinhas & 0 & 0 & 0 & 0 & 0 & 0 & 0 & 0 & 0 & 0 & 0 & 0 & 0 & 0 & 0 & 0 & 5 & 4 & 0 & 0 \\
\hline São Bonifácio & Florianópolis & 0 & 0 & 0 & 0 & 0 & 0 & 0 & 0 & 0 & 0 & 0 & 0 & 0 & 0 & 0 & 0 & 0 & 0 & 0 & 0 \\
\hline São Carlos & Chapecó & 0 & 0 & 0 & 0 & 0 & 0 & 0 & 0 & 0 & 0 & 0 & 0 & 0 & 0 & 0 & 0 & 0 & 0 & 0 & 0 \\
\hline São Domingos & Concórdia & 0 & 0 & 0 & 0 & 0 & 0 & 0 & 0 & 0 & 0 & 0 & 0 & 6 & 1 & 0 & 0 & 0 & 0 & 0 & 0 \\
\hline
\end{tabular}




\begin{tabular}{|c|c|c|c|c|c|c|c|c|c|c|c|c|c|c|c|c|c|c|c|c|c|}
\hline \multirow{3}{*}{ Municipio } & \multirow{3}{*}{$\mathrm{CTA}$} & \multicolumn{20}{|c|}{ Meses } \\
\hline & & \multicolumn{2}{|c|}{ Out 90} & \multicolumn{2}{|c|}{ Nov 90} & \multicolumn{2}{|c|}{ Dez 90} & \multicolumn{2}{|c|}{ Wan 91} & \multicolumn{2}{|c|}{ fov 91} & \multicolumn{2}{|c|}{ (tar 91} & \multicolumn{2}{|c|}{ Abr 91} & \multicolumn{2}{|c|}{ Ma. 91} & \multicolumn{2}{|c|}{ Jun 9} & \multicolumn{2}{|c|}{ उuा 91} \\
\hline & & Casos & Focos & Casos & Focos & Casos & Focos & Casos & Focos & Carsos & Focos & $\mathrm{Casos}$ & Foros & Casos & Focos & Casos & Focos & Casos & Foros & Casos & Focos \\
\hline São Francisco do Sul & Itajai & 0 & 0 & 0 & 0 & 0 & 0 & 0 & 0 & 0 & 0 & 0 & 0 & 0 & 0 & 0 & 0 & 0 & 0 & 0 & 0 \\
\hline São João Batista & Florianópolis & 0 & 0 & 0 & 0 & 0 & 0 & 0 & 0 & 0 & 0 & 0 & 0 & 0 & 0 & 0 & 0 & 0 & 0 & 0 & 0 \\
\hline São João do Sul & Urussanga & 0 & 0 & 0 & 0 & 0 & 0 & 0 & 0 & 0 & 0 & 50 & 1 & 56 & 3 & 25 & 1 & 0 & 0 & 0 & 0 \\
\hline São João D'Oeste & Chapecó & 0 & 0 & 0 & 0 & 0 & 0 & 0 & 0 & 0 & 0 & 0 & 0 & 0 & 0 & 0 & 0 & 0 & 0 & 0 & 0 \\
\hline São Joaquim & Lages & 0 & 0 & 536 & 15 & 0 & 0 & 4 & 1 & 12 & 1 & 0 & 0 & 0 & 0 & 0 & 0 & 0 & 0 & 0 & 0 \\
\hline São José & Florianópolis & 0 & 0 & 0 & 0 & 0 & 0 & 0 & 0 & 0 & 0 & 0 & 0 & 0 & 0 & 0 & 0 & 0 & 0 & 0 & 0 \\
\hline São Ludgero & Urussanga & 0 & 0 & 0 & 0 & 0 & 0 & 0 & 0 & 0 & 0 & 0 & 0 & 0 & 0 & 0 & 0 & 0 & 0 & 0 & 0 \\
\hline São Martinho & Urussanga & 0 & 0 & 0 & 0 & 0 & 0 & 0 & 0 & 0 & 0 & 0 & 0 & 0 & 0 & 0 & 0 & 0 & 0 & 0 & 0 \\
\hline Saudade & Chapecó & 0 & 0 & 0 & 0 & 0 & 0 & 0 & 0 & 0 & 0 & 0 & 0 & 0 & 0 & 0 & 0 & 0 & 0 & 0 & 0 \\
\hline Schroeder & Itajai & 0 & 0 & 0 & 0 & 0 & 0 & 0 & 0 & 0 & 0 & 0 & 0 & 0 & 0 & 0 & 0 & 0 & 0 & 0 & 0 \\
\hline Seara & Concórdia & 0 & 0 & 0 & 0 & 0 & 0 & 0 & 0 & 0 & 0 & 0 & 0 & 0 & 0 & 0 & 0 & 0 & 0 & 0 & 0 \\
\hline Serra Alta & Chapecó & 0 & 0 & 0 & 0 & 0 & 0 & 0 & 0 & 0 & 0 & 0 & 0 & 0 & 0 & 0 & 0 & 0 & 0 & 0 & 0 \\
\hline Siderópolis & Urussanga & 0 & 0 & 0 & 0 & 0 & 0 & 0 & 0 & 0 & 0 & 0 & 0 & 0 & 0 & 0 & 0 & 0 & 0 & 0 & 0 \\
\hline Sombrio & Urussanga & 0 & 0 & 9 & 1 & 0 & 0 & 0 & 0 & 0 & 0 & 0 & 0 & 7 & 2 & 0 & 0 & 0 & 0 & 0 & 0 \\
\hline Sul Brasil & Chapecó & 0 & 0 & 0 & 0 & 0 & 0 & 0 & 0 & 0 & 0 & 0 & 0 & 0 & 0 & 0 & 0 & 0 & 0 & 0 & 0 \\
\hline Taió & Ituporanga & 32 & 2 & 25 & 1 & 277 & 2 & 0 & 0 & 0 & 0 & 0 & 0 & 0 & 0 & 0 & 0 & 0 & 0 & 0 & 0 \\
\hline Tangará & Campos Novos & 0 & 0 & 0 & 0 & 0 & 0 & 0 & 0 & 0 & 0 & 0 & 0 & 0 & 0 & 0 & 0 & 0 & 0 & 0 & 0 \\
\hline Tijucas & Florianópolis & 0 & 0 & 0 & 0 & 0 & 0 & 0 & 0 & 0 & 0 & 0 & 0 & 0 & 0 & 0 & 0 & 0 & 0 & 0 & 0 \\
\hline Timbé do Sul & Urussanga & 0 & 0 & 1 & 1 & 0 & 0 & 0 & 0 & 0 & 0 & 0 & 0 & 0 & 0 & 0 & 0 & 0 & 0 & 0 & 0 \\
\hline Timbó & Itajai & 0 & 0 & 0 & 0 & 0 & 0 & 0 & 0 & 0 & 0 & 0 & 0 & 0 & 0 & 0 & 0 & 0 & 0 & 0 & 0 \\
\hline Timbó Grande & Caçador & 0 & 0 & 0 & 0 & 0 & 0 & 77 & 2 & 0 & 0 & 0 & 0 & 0 & 0 & 0 & 0 & 0 & 0 & $\overline{0}$ & 0 \\
\hline Três Barras & Canoinhas & 0 & 0 & 0 & 0 & 0 & 0 & 0 & 0 & 0 & 0 & 0 & 0 & 0 & 0 & 0 & 0 & 0 & 0 & 0 & 0 \\
\hline Treze de Maio & Urussanga & 0 & 0 & 0 & 0 & 0 & 0 & 0 & 0 & 0 & 0 & 0 & 0 & 0 & 0 & 0 & 0 & 0 & 0 & 0 & 0 \\
\hline
\end{tabular}




\begin{tabular}{|c|c|c|c|c|c|c|c|c|c|c|c|c|c|c|c|c|c|c|c|c|c|}
\hline \multirow{3}{*}{ Municipio } & \multirow{3}{*}{$\mathrm{CA}$} & \multicolumn{20}{|c|}{ Meses } \\
\hline & & \multicolumn{2}{|c|}{ Out 90} & \multicolumn{2}{|c|}{ Nov 90} & \multicolumn{2}{|c|}{ Dez. 90} & \multicolumn{2}{|c|}{6201} & \multicolumn{2}{|c|}{ Fev 91} & \multicolumn{2}{|c|}{ Nar 91} & \multicolumn{2}{|c|}{ Alor 91} & \multicolumn{2}{|c|}{$\mathrm{Ma} / 9 \mathrm{I}$} & \multicolumn{2}{|c|}{$10 n 91$} & \multicolumn{2}{|c|}{$\mathrm{Jul} 91$} \\
\hline & & Casos & Tocos & Casos & fooos & Casos & Foods & Caro & focos & Casos & Fooos & Casos & Focos & Caros & Focos & Casos & Focos & Casos & Foros & Casos & Focos \\
\hline Treze Tílias & Campos Novos & 0 & 0 & 0 & 0 & 0 & 0 & 0 & 0 & 0 & 0 & 0 & 0 & 0 & 0 & 0 & 0 & 0 & 0 & 0 & 0 \\
\hline Trombudo Central & Ituporanga & 0 & 0 & 0 & 0 & 0 & 0 & 0 & 0 & 0 & 0 & 0 & 0 & 0 & 0 & 0 & 0 & 0 & 0 & 0 & 0 \\
\hline Tubarão & Urussanga & 0 & 0 & 0 & 0 & 0 & 0 & 0 & 0 & 0 & 0 & 1046 & 2 & 4 & 1 & 0 & 0 & 1 & 1 & 5 & 1 \\
\hline Tunópolis & Chapecó & 0 & 0 & 0 & 0 & 0 & 0 & 0 & 0 & 0 & 0 & 0 & 0 & 0 & 0 & 0 & 0 & 0 & 0 & 0 & 0 \\
\hline Turvo & Urussanga & 0 & 0 & 0 & 0 & 0 & 0 & 0 & 0 & 0 & 0 & 0 & 0 & 0 & 0 & 0 & 0 & 0 & 0 & 0 & 0 \\
\hline União D'Oeste & Chapecó & 0 & 0 & 0 & 0 & 0 & 0 & 0 & 0 & 0 & 0 & 0 & 0 & 0 & 0 & 0 & 0 & 0 & 0 & 0 & 0 \\
\hline Urubici & Lages & 0 & 0 & 312 & 9 & 0 & 0 & 0 & 0 & 0 & 0 & 0 & 0 & 0 & 0 & 0 & 0 & 0 & 0 & 0 & 0 \\
\hline Urupema & Lages & 0 & 0 & 0 & 0 & 0 & 0 & 35 & 1 & 7 & 1 & 0 & 0 & 0 & 0 & 0 & 0 & 0 & 0 & 0 & 0 \\
\hline Urussanga & Urussanga & 0 & 0 & 0 & 0 & 0 & 0 & 0 & 0 & 0 & 0 & 0 & 0 & 0 & 0 & 0 & 0 & 0 & 0 & 0 & 0 \\
\hline Vargeão & Concórdia & 0 & 0 & 0 & 0 & 0 & 0 & 0 & 0 & 0 & 0 & 0 & 0 & 0 & 0 & 0 & 0 & 0 & 0 & 0 & 0 \\
\hline Vargem & Campos Novos & 0 & 0 & 0 & 0 & 0 & 0 & 0 & 0 & 0 & 0 & 0 & 0 & 0 & 0 & 0 & 0 & 0 & 0 & 0 & 0 \\
\hline Vidal Ramos & Ituporanga & 0 & 0 & 0 & 0 & 0 & 0 & 0 & 0 & 0 & 0 & 0 & 0 & 0 & 0 & 0 & 0 & 0 & 0 & 0 & 0 \\
\hline Videira & Caçador & 0 & 0 & 0 & 0 & 0 & 0 & 0 & 0 & 0 & 0 & 0 & 0 & 0 & 0 & 0 & 0 & 0 & 0 & 0 & 0 \\
\hline Vitor Meireles & Ituporanga & 0 & 0 & 0 & 0 & 0 & 0 & 0 & 0 & 0 & 0 & 0 & 0 & 0 & 0 & 0 & 0 & 0 & 0 & 0 & 0 \\
\hline Witmarsum & Ituporanga & 0 & 0 & 0 & 0 & 0 & 0 & 0 & 0 & 0 & 0 & 0 & 0 & 0 & 0 & 0 & 0 & 0 & 0 & 0 & 0 \\
\hline Xanxerê & Concórdia & 0 & 0 & 0 & 0 & 0 & 0 & 0 & 0 & 0 & 0 & 0 & 0 & 0 & 0 & 0 & 1 & 0 & 0 & 0 & 0 \\
\hline Xavantina & Concórdia & 0 & 0 & 0 & 0 & 0 & 0 & 0 & 0 & 0 & 0 & 0 & 0 & 0 & 0 & 0 & 0 & 0 & 0 & 0 & 0 \\
\hline Xaxim & Concórdia & 0 & 0 & 0 & 0 & 0 & 0 & 0 & 0 & 0 & 0 & 0 & 0 & 30 & 4 & 12 & 2 & 0 & 0 & 0 & 0 \\
\hline Total & & 223 & 5 & 3456 & 76 & 1304 & 51 & 453 & 20 & 284 & 3 & 1318 & 7 & 396 & 49 & 793 & 98 & 114 & 27 & 5 & 1 \\
\hline
\end{tabular}

